\title{
\#USGS
}

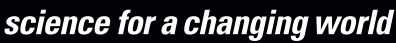

Prepared in cooperation with the Pierce Conservation District and the Washington State Department of Ecology

\section{Hydrogeologic Framework, Groundwater Movement, and Water Budget in the Chambers-Clover Creek Watershed and Vicinity, Pierce County, Washington}

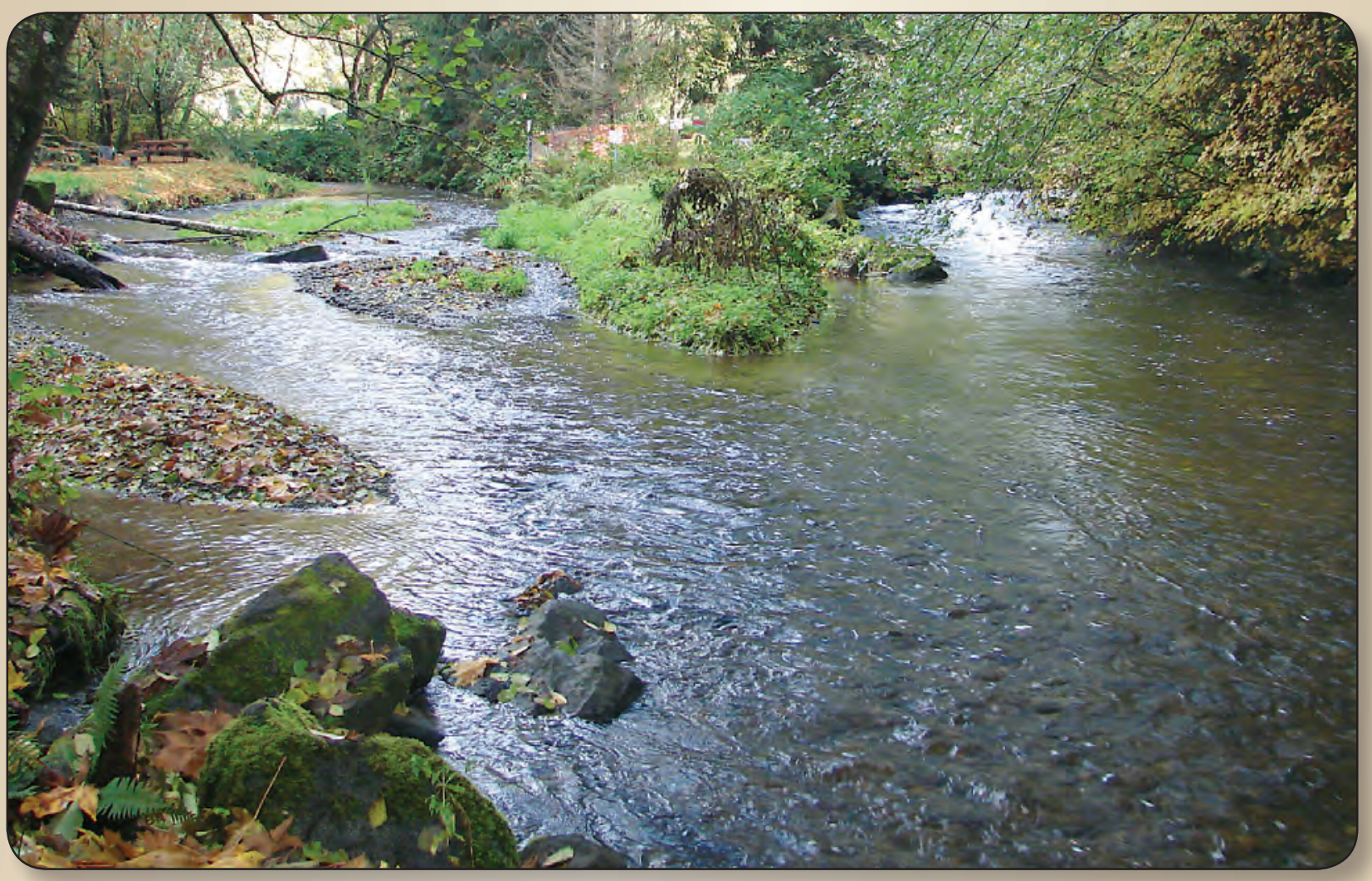

Scientific Investigations Report 2010-5055 
Cover: Photograph showing confluence of Chambers Creek and Leach Creek.

Photograph taken by Don Russell, Chambers-Clover Creek project team member, 2009. 


\section{Hydrogeologic Framework, Groundwater Movement, and Water Budget in the Chambers-Clover Creek Watershed and Vicinity, Pierce County, Washington}

By Mark E. Savoca, Wendy B. Welch, Kenneth H. Johnson, R.C. Lane, U.S. Geological Survey; Burt G. Clothier, Robinson \& Noble Inc., and Elisabeth T. Fasser, U.S. Geological Survey

Prepared in cooperation with the Pierce Conservation District and the Washington State Department of Ecology

Scientific Investigations Report 2010-5055 


\section{U.S. Department of the Interior \\ KEN SALAZAR, Secretary \\ U.S. Geological Survey \\ Marcia K. McNutt, Director}

U.S. Geological Survey, Reston, Virginia: 2010

For more information on the USGS - the Federal source for science about the Earth, its natural and living resources, natural hazards, and the environment, visit http://www.usgs.gov or call 1-888-ASK-USGS

For an overview of USGS information products, including maps, imagery, and publications, visit http://www.usgs.gov/pubprod

To order this and other USGS information products, visit http://store.usgs.gov

Any use of trade, product, or firm names is for descriptive purposes only and does not imply endorsement by the U.S. Government.

Although this report is in the public domain, permission must be secured from the individual copyright owners to reproduce any copyrighted materials contained within this report.

Suggested citation:

Savoca, M.E., Welch, W.B., Johnson, K.H., Lane, R.C., Clothier, B.G., and Fasser, E.T., 2010, Hydrogeologic framework, groundwater movement, and water budget in the Chambers-Clover Creek Watershed and vicinity, Pierce County, Washington: U.S. Geological Survey Scientific Investigations Report 2010-5055, 46 p. 


\section{Contents}

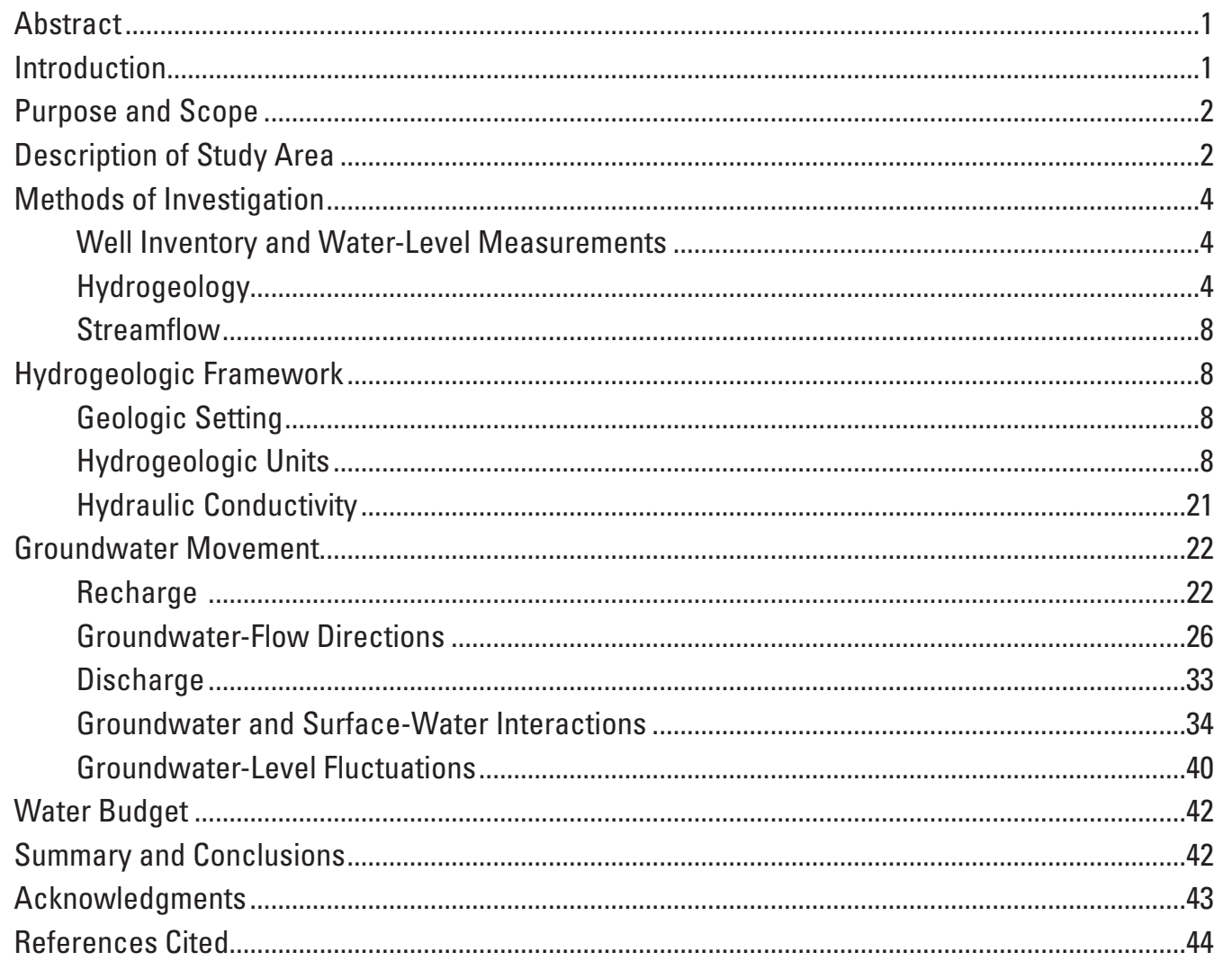

\section{Plates}

Plate 1. Maps showing locations of selected wells and surface-water discharge sites in the Chambers-Clover Creek Watershed and vicinity, Pierce County, Washington.

Plate 2. Map and hydrogeologic sections showing surficial hydrogeology, hydrogeologic units, and locations of selected wells in the Chambers-Clover Creek Watershed and vicinity, Pierce County, Washington. 


\section{Figures}

Figure 1. Map showing location of Chambers-Clover Creek Watershed and vicinity, Washington

Figure 2. Graphs showing residuals between hydrogeologic unit correlation altitudes and altitudes of interpolated digital hydrogeologic surfaces

Figure 3. Map showing extent and thickness of AL alluvial valley aquifer in Chambers-Clover Creek Watershed and vicinity, Washington

Figure 4. Map showing extent and thickness of $A 1$ aquifer in Chambers-Clover Creek Watershed and vicinity, Washington

Figure 5. Map showing extent and thickness of A2 confining unit in Chambers-Clover Creek Watershed and vicinity, Washington

Figure 6. Map showing extent and thickness of $A 3$ aquifer in Chambers-Clover Creek Watershed and vicinity, Washington.

Figure 7. Map showing extent and thickness of $B$ confining unit in Chambers-Clover Creek Watershed and vicinity, Washington

Figure 8. Map showing extent and thickness of $C$ aquifer in Chambers-Clover Creek Watershed and vicinity, Washington.

Figure 9. Map showing extent and thickness of $D$ confining unit in Chambers-Clover Creek Watershed and vicinity, Washington

Figure 10. Map showing extent and thickness of $E$ aquifer in Chambers-Clover Creek Watershed and vicinity, Washington

Figure 11. Map showing extent and thickness of $\mathrm{F}$ confining unit in Chambers-Clover Creek Watershed and vicinity, Washington

Figure 12. Map showing extent and thickness of $G$ undifferentiated deposits in Chambers-Clover Creek Watershed and vicinity, Washington

Figure 13. Map showing average annual precipitation, canopy cover, and impervious surface across the Chambers-Clover Creek Watershed and vicinity, Washington, September 2006-August 2008

Figure 14. Graph showing precipitation-recharge relations used in this study, Chambers-Clover Creek Watershed and vicinity, Washington

Figure 15. Map showing distribution of average annual groundwater recharge from precipitation in Chambers-Clover Creek Watershed and vicinity, Washington, September 2006-August 2008

Figure 16. Map showing water-level altitudes and direction of groundwater flow in AL alluvial valley aquifer, Chambers-Clover Creek Watershed and vicinity, Washington, September 2006-September 2008

Figure 17. Map showing water-level altitudes and direction of groundwater flow in A1 aquifer, Chambers-Clover Creek Watershed and vicinity, Washington, September 2006-September 2008

Figure 18. Map showing water-level altitudes and direction of groundwater flow in A3 aquifer, Chambers-Clover Creek Watershed and vicinity, Washington, September 2006-September 2008

Figure 19. Map showing water-level altitudes and direction of groundwater flow in C aquifer, Chambers-Clover Creek Watershed and vicinity, Washington, September 2006-September 2008 


\section{Figures-Continued}

Figure 20. Map showing water-level altitudes and direction of groundwater flow in $\mathrm{E}$ aquifer, Chambers-Clover Creek Watershed and vicinity, Washington, September 2006-September 2008 .

Figure 21. Map showing water-level altitudes and direction of groundwater flow in $\mathrm{G}$ undifferentiated deposits, Chambers-Clover Creek Watershed and vicinity, Washington, September 2006-September 2008

Figure 22. Graph showing mean monthly streamflow at U.S. Geological Survey streamflow-gaging stations for Clover Creek, Chambers Creek, and Clarks Creek, Chambers-Clover Creek Watershed and vicinity, Washington

Figure 23. Graph showing daily streamflow for U.S. Geological Survey streamflow-gaging stations on Clover Creek, Chambers Creek, and Clarks Creek, Chambers-Clover Creek Watershed and vicinity, Washington, September 5-15, 2007

Figure 24. Graph showing daily streamflow for U.S. Geological Survey streamflow-gaging stations on Clover Creek, Chambers Creek, and Clarks Creek, Chambers-Clover Creek Watershed and vicinity, Washington, July 4-14, 2008

Figure 25. Hydrographs of water levels in well 20N/02E-35P01, stream stage at U.S. Geological Survey streamflow-gaging station on Chambers Creek, and precipitation at Tacoma, Chambers-Clover Creek Watershed and vicinity, Washington, September 2007-September 2008

Figure 26. Hydrographs of water levels in well 19N02E-19LF402C, stream stage at U.S. Geological Survey streamflow-gaging station on Clover Creek, and precipitation at Tacoma, Chambers-Clover Creek Watershed and vicinity, Washington, September 2007-September 2008

\section{Tables}

Table 1. Hydrogeologic units defined in this study and correlation with geologic and hydrostratigraphic units from previous investigations

Table 2. Statistics for interpolated digital hydrogeologic surfaces.

Table 3. Summary of hydraulic conductivity values estimated from specific-capacity data and aquifers tests, by hydrogeologic unit, Chambers-Clover Creek Watershed and vicinity, Washington

Table 4. Synoptic streamflow measurements and estimates of evaporative loss from lakes used to determine groundwater discharge in the Chambers-Clover Creek Watershed and vicinity, Washington, September 2007 and July 2008

Table 5. Synoptic streamflow measurements and estimates of gains and losses in the Chambers-Clover Creek Watershed and vicinity, Washington, September 2007 and July 2008

Table 6. Summary of groundwater-level fluctuations and well depths by hydrogeologic unit, Chambers-Clover Creek Watershed, Washington, March 2007 through September 2008.

Table 7. Estimated annual water budget for Chambers-Clover Creek Watershed and vicinity, Washington, September 1, 2006, to August 31, 2008 


\title{
Conversion Factors and Datums
}

\author{
Conversion Factors
}

\begin{tabular}{|c|c|c|}
\hline Multiply & By & To obtain \\
\hline acre-foot (acre-ft) & 1,233 & cubic meter \\
\hline acre-foot per year (acre-ft/yr) & 1,233 & cubic meter per year \\
\hline cubic foot per second $\left(\mathrm{ft}^{3} / \mathrm{s}\right)$ & 0.02832 & cubic meter per second $\left(\mathrm{m}^{3} / \mathrm{s}\right)$ \\
\hline cubic foot per day $\left(\mathrm{ft}^{3} / \mathrm{d}\right)$ & 0.02832 & cubic meter per day $\left(\mathrm{m}^{3} / \mathrm{d}\right)$ \\
\hline cubic foot per second per mile $\left(\mathrm{ft}^{3} / \mathrm{s}\right) / \mathrm{mi}$ & 0.01760 & $\begin{array}{l}\text { cubic meter per second per kilometer } \\
\qquad\left(\mathrm{m}^{3} / \mathrm{s} / \mathrm{km}\right)\end{array}$ \\
\hline $\begin{array}{l}\text { cubic foot per second per square mile } \\
\qquad\left(\mathrm{ft}^{3} / \mathrm{s}\right) / \mathrm{mi}^{2}\end{array}$ & 0.01093 & $\begin{array}{l}\text { cubic meter per second per square kilometer } \\
\qquad\left(\mathrm{m}^{3} / \mathrm{s} / \mathrm{km}_{2}\right)\end{array}$ \\
\hline inch (in.) & 2.54 & centimeter $(\mathrm{cm})$ \\
\hline inch (in.) & 25.4 & millimeter (mm) \\
\hline inch per year (in/yr) & 25.4 & millimeter per year $(\mathrm{mm} / \mathrm{yr})$ \\
\hline foot $(\mathrm{ft})$ & 0.3048 & $\operatorname{meter}(\mathrm{m})$ \\
\hline foot per day (ft/d) & 0.3048 & meter per day $(\mathrm{m} / \mathrm{d})$ \\
\hline gallon (gal) & 0.003785 & cubic meter $\left(\mathrm{m}^{3}\right)$ \\
\hline gallon per day (gal/d) & 0.003785 & cubic meter per day $\left(\mathrm{m}^{3} / \mathrm{d}\right)$ \\
\hline square mile $\left(\mathrm{mi}^{2}\right)$ & 2.590 & square kilometer $\left(\mathrm{km}^{2}\right)$ \\
\hline
\end{tabular}

Temperature in degrees Celsius $\left({ }^{\circ} \mathrm{C}\right)$ may be converted to degrees Fahrenheit ( $\left.{ }^{\circ} \mathrm{F}\right)$ as follows:

${ }^{\circ} \mathrm{F}=\left(1.8 x^{\circ} \mathrm{C}\right)+32$.

Temperature in degrees Fahrenheit $\left({ }^{\circ} \mathrm{F}\right)$ may be converted to degrees Celsius $\left({ }^{\circ} \mathrm{C}\right)$ as follows:

${ }^{\circ} \mathrm{C}=\left({ }^{\circ} \mathrm{F}-32\right) / 1.8$.

Datums

Vertical coordinate information is referenced to the National Geodetic Vertical Datum of 1929 (NGVD 29), referred to in this report as "sea level."

Horizontal coordinate information is referenced to the North American Datum of 1983 (NAD 83).

Altitude, as used in this report, refers to distance above or below sea level.

\section{Abbreviations and Acronyms}

$\begin{array}{ll}\text { ANUDEM } & \text { Australian National University Digital Elevation Model } \\ \text { DEM } & \text { digital elevation model } \\ \text { CCCW } & \text { Chambers-Clover Creek Watershed } \\ \text { GIS } & \text { geographic information system } \\ \text { GPS } & \text { global positioning system } \\ \text { LiDAR } & \text { light detections and ranging } \\ \text { NAD } & \text { North American Datum } \\ \text { NGVD } & \text { National Geodetic Vertical Datum } \\ \text { NWS } & \text { National Weather Service } \\ \text { PRISM } & \text { parameter elevation regressions on Independent Slopes Model } \\ \text { RCW } & \text { Revised Code Washington } \\ \text { USGS } & \text { U.S. Geological Survey } \\ \text { WRIA } & \text { Water Resources Inventory Area }\end{array}$




\section{Well-Numbering System}

Wells in the State of Washington are assigned a local well number that identifies each well based on its location in a township, range, section, and 40 -acre tract. For example, local well number 20N/02E-26C01 indicates that the well is in township 20 north of the Willamette Base Line, and range 2 east of the Willamette Meridian. The numbers immediately following the hyphen indicate the section (26) in the township, and the letter following the section (C) gives the 40 -acre tract of the section. The two-digit sequence number (01) following the letter is used to distinguish individual wells in the same 40 -acre tract. $A$ " $D$ " following the sequence number indicates a well that has been deepened. In the plates of this report, wells are identified using only the section and 40-acre tract, such as 26C01; the township and range are shown on the map borders.

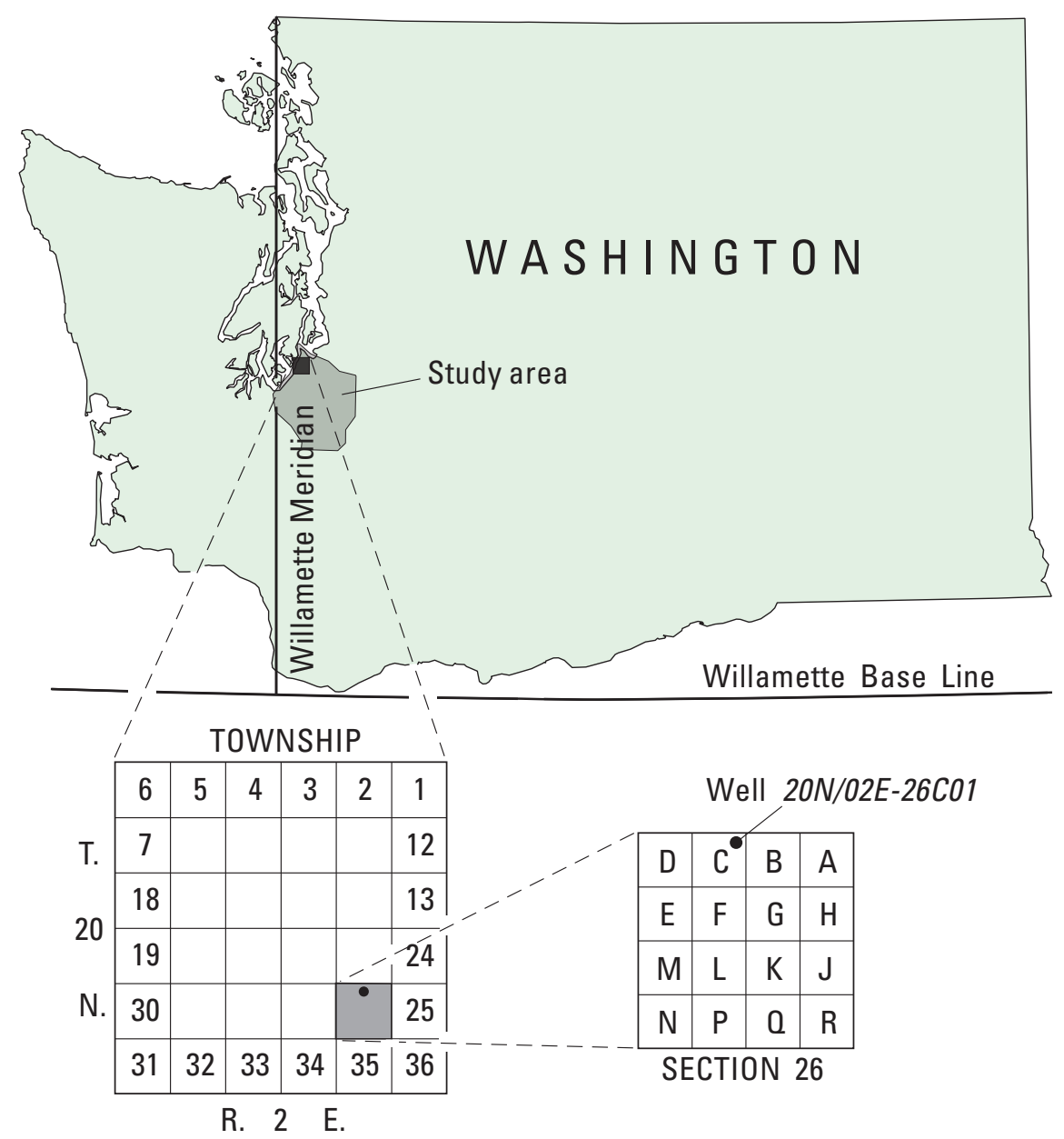

Diagram showing well-numbering system used in Washington. 
viii

This page intentionally left blank. 


\title{
Hydrogeologic Framework, Groundwater Movement, and Water Budget in the Chambers-Clover Creek Watershed and Vicinity, Pierce County, Washington
}

\author{
By Mark E. Savoca, Wendy B. Welch, Kenneth H. Johnson, R.C. Lane, U.S. Geological Survey; Burt G. Clothier, \\ Robinson \& Noble Inc., and Elisabeth T. Fasser, U.S. Geological Survey
}

\section{Abstract}

This report presents information used to characterize the groundwater-flow system in the Chambers-Clover Creek Watershed and vicinity, and includes descriptions of the geology and hydrogeologic framework; groundwater recharge and discharge; groundwater levels and flow directions;

seasonal groundwater level fluctuations; interactions between aquifers and the surface-water system; and a water budget. The study area covers about 706 square miles in western Pierce County, Washington, and extends north to the Puyallup River, southwest to the Nisqually River, and is bounded on the south and east by foothills of the Cascade Range and on the west by Puget Sound. The area is underlain by a northwest-thickening sequence of unconsolidated glacial and interglacial deposits which overlie sedimentary and volcanic bedrock units that crop out in the foothills along the southern and southeastern margin of the study area. Geologic units were grouped into 11 hydrogeologic units consisting of aquifers, confining units, and an underlying bedrock unit. A surficial hydrogeologic unit map was developed and used with well information from 450 drillers' logs to construct 6 hydrogeologic sections, and unit extent and thickness maps.

Groundwater in unconsolidated glacial and interglacial aquifers generally flows to the northwest towards Puget Sound, and to the north and northeast towards the Puyallup River. These generalized flow patterns likely are complicated by the presence of low permeability confining units that separate discontinuous bodies of aquifer material and act as local groundwater-flow barriers. Water levels in wells completed in the unconsolidated hydrogeologic units show seasonal variations ranging from less than 1 to about 50 feet. The largest groundwater-level fluctuation (78 feet) observed during the monitoring period (March 2007-September 2008) was in a well completed in the bedrock unit.

Synoptic streamflow measurements made in September 2007 and July 2008 indicated a total groundwater discharge to streams in the study area of 87,310 and 92,160 acre-feet per year, respectively. The synoptic streamflow measurements show a complex pattern of gains and losses to streamflows that varies throughout the study area, and appears to be influenced in places by local topography. Groundwater discharge occurs at numerous springs in the area and the total previously reported discharge of springs in the area is approximately 80,000 acre-feet per year. There are, in addition, many unmeasured springs and the total spring discharge in the area is unknown.

The water-budget area $\left(432 \mathrm{mi}^{2}\right.$ located within the larger study area) received an annual average (September1, 2006, to August 31, 2008) of about 1,025,000 acre-ft or about 45 inches of precipitation a year. About 44 percent of precipitation enters the groundwater system as recharge. Almost one-half of this recharge (49 percent) discharges to the Puyallup and Nisqually Rivers and leaves the groundwater system as submarine groundwater discharge to Puget Sound. The remaining groundwater recharge discharges to streams (20 percent) and springs (18 percent) or is withdrawn from wells (13 percent).

\section{Introduction}

In 1998, the Washington State Legislature established the Washington State Watershed Management Act (codified under RCW 90.82) to address diminishing water availability and quality and the loss of critical habitat for fish and wildlife. Watershed studies under this act were started in 1998 in the Chambers-Clover Creek Watershed (CCCW) Water Resources Inventory Area (WRIA 12) by a group of Initiating Governments and local stakeholders (Planning Unit). After completion of a technical assessment of the watershed, some members of the Planning Unit concluded that additional data, including development of a numerical groundwater-flow model, would contribute to an improved understanding of water resources in the $\mathrm{CCCW}$. 
In May 2006, the U.S. Geological Survey (USGS) in cooperation with Pierce Conservation District (serving as sponsoring agency for local public water suppliers and Pierce County Surface Water Management Division) and the Washington State Department of Ecology began a project to characterize the groundwater-flow system in the $\mathrm{CCCW}$ and vicinity. A second phase of this project will integrate this and other information into a numerical groundwater-flow model to contribute to an improved understanding of water resources in the CCCW.

\section{Purpose and Scope}

This report presents information used to characterize the groundwater-flow system in the CCCW and vicinity. The report includes descriptions of the geology and hydrogeologic framework of the area; groundwater recharge and discharge; groundwater levels and flow directions; seasonal groundwater-level fluctuations; interactions between aquifers and the surface-water system; and a water budget.

\section{Description of Study Area}

The study area covers about $706 \mathrm{mi}^{2}$ in western Pierce County, Washington (fig. 1), and initially was selected to include major hydrologic features that could be used as regional model boundaries during the second phase of this project. The study area defines the region of groundwater and surface-water data collection, and coincides with the area in which the hydrogeologic framework was developed. The study area extends northeast to the Puyallup River, southwest to the Nisqually River, and is bounded on the south and east by foothills of the Cascade Range and on the northwest by Puget Sound. The water-budget area $\left(432 \mathrm{mi}^{2}\right)$ is located within the larger study area (fig. 1), and was delineated after completion of the hydrogeologic framework to more closely approximate the area to be used in development of the numerical flow model of the CCCW and vicinity. The water-budget area is bounded by the Puyallup and Nisqually Rivers, Puget Sound, and extends southeast to Tanwax Creek. The water-budget area includes most of the groundwater-level and all streamflow data- collection sites. Tanwax Creek approximates the southeastern extent of most of the waterbearing hydrogeologic units (pls. 1 and 2). The Puyallup and Nisqually Rivers and Puget Sound constitute regional scale hydrologic features that will coincide with model boundaries. In this report, the water-budget area defines the region in which water-budget components were estimated.
The study area is underlain by a northwest-thickening sequence of unconsolidated glacial (till and outwash) and interglacial (fluvial and lacustrine) deposits. Sedimentary and volcanic bedrock units underlie the unconsolidated deposits and crop out in the foothills along the southern and southeastern margin of the study area. Land-surface altitude in the study area ranges from sea level along the Puget Sound coast and western extent of major river valleys to near $2,340 \mathrm{ft}$ in the southeastern foothills.

The Puyallup and Nisqually Rivers occupy large, relatively flat alluvial valleys that are separated by a broad, poorly drained upland area that covers most of the study area. The northwest-flowing Puyallup River receives streamflow from several north-flowing streams (Swan, Clear, and Clarks Creeks) that originate in the northern uplands. Chambers and Clover Creeks drain much of the central uplands and flow westward to the Puget Sound. Muck and Lacamas Creeks, and several small tributaries to the northwest-flowing Nisqually River drain the southern part of the study area. Many stream reaches flow year-round; however, intermittent and ephemeral flow conditions also are common in many stream reaches, especially during the summer months. Numerous springs are present throughout the study area, and contribute to late-summer baseflow to streams and year-round groundwater discharge to Puget Sound along shoreline bluffs. Major lakes in the study area include Steilacoom, Gravelly, American, and Spanaway. These lakes likely are of glacial (kettle) origin and generally reflect water levels in the shallow groundwater-flow system. Outflows from Gravelly and American Lakes are unregulated. Steilacoom and Spanaway Lakes have fixed-elevation controlled outfalls. Many small lakes in the area are associated with poorly drained wetland areas typically formed on glacial till deposits.

The study area has a temperate marine climate with warm, dry summers, and cool, wet winters. Temperatures are moderated by the Pacific Ocean and Puget Sound. The ocean provides an abundant supply of moisture for winter storms that typically approach the area from the southwest. Mean annual precipitation (average annual precipitation for 1971-2000) is $38.9 \mathrm{in}$. at Tacoma, and $43.1 \mathrm{in}$. at McMillin Reservoir (National Oceanic and Atmospheric Administration, 2007). The distribution of precipitation varies throughout the year. Summers (June-August) typically are dry with a mean total precipitation of 3.3 in. at Tacoma, and 4.6 in. at McMillin Reservoir. Winters (December-February) are wetter than summers with a mean total precipitation of $15.7 \mathrm{in}$. at Tacoma and 16.1 in. at McMillin Reservoir. Mean monthly temperature (average monthly temperature for 1971-2000) at these locations ranges from about $39^{\circ} \mathrm{F}$ in January to about $64^{\circ} \mathrm{F}$ in August (National Oceanic and Atmospheric Administration, 2007). 


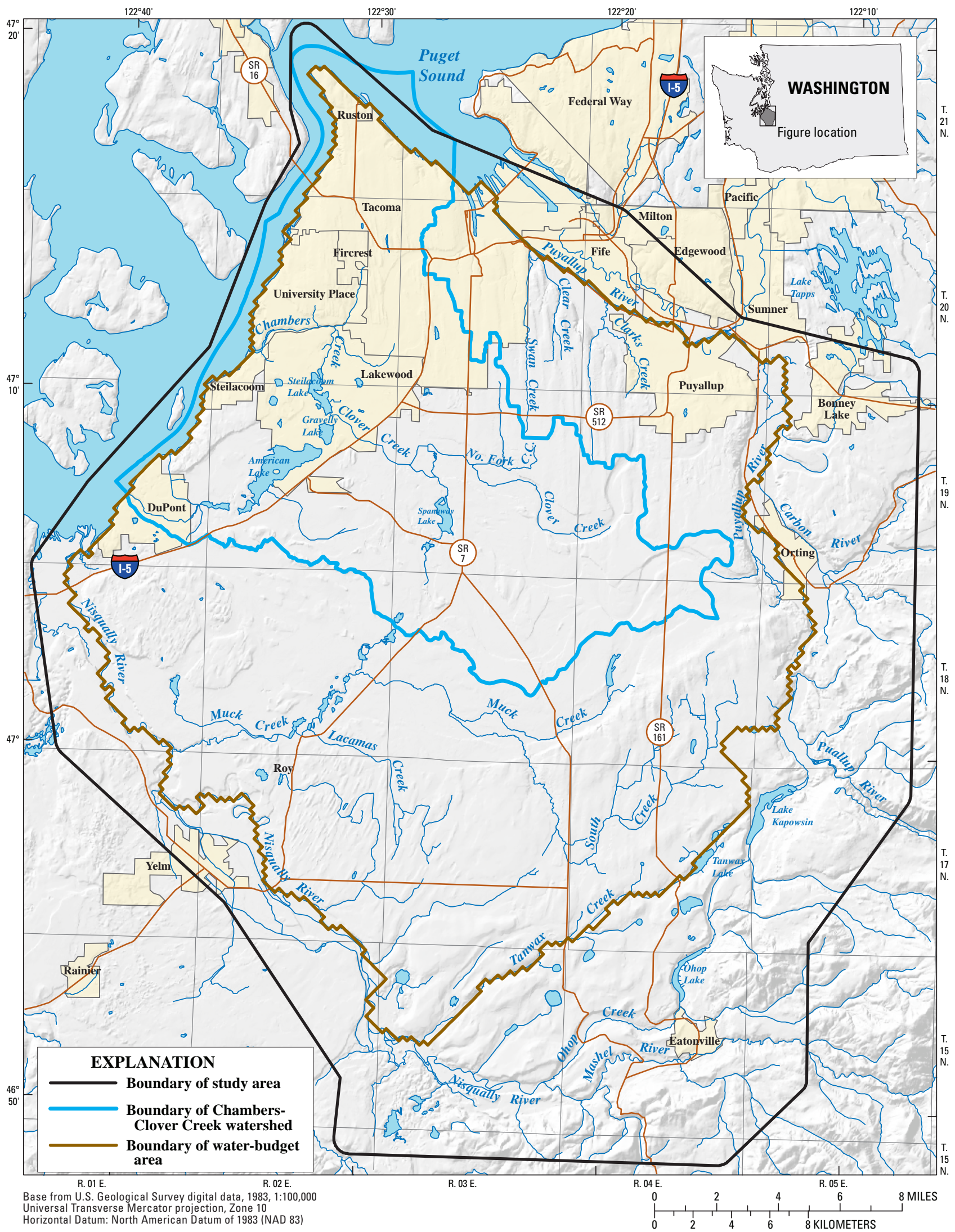

Figure 1. Location of Chambers-Clover Creek Watershed and vicinity, Washington. 


\section{Methods of Investigation}

Methods used to compile and analyze information for the characterization of the groundwater-flow system in the study area are described in this section. Methods used to determine groundwater movement and estimate water budget are included with the respective sections later in this report.

\section{Well Inventory and Water-Level Measurements}

The groundwater-flow system was characterized based on the analysis of spatially distributed information about groundwater levels and the physical and hydraulic properties of the geologic units encountered during well construction. Spatial information was obtained through the measurement of water levels in wells, and the compilation and analysis of hydrogeologic descriptions and well tests from well drillers' logs. Well records that document the drilling (drillers' $\log$ description of borehole lithology), construction, and, sometimes, hydraulic testing of wells were compiled from USGS and Washington State Department of Ecology databases to identify potential wells to be used in this study. Candidate wells were selected for field inventory based on the location and depth of the well, and the availability of a complete well record with drillers' log. Well records with insufficient well location and construction information or incomplete or poorly constrained drillers' logs were not considered for field inventory and were not used in this study. The goal of the inventory was to obtain an even distribution of wells throughout the study area. However, this was not possible for the entire study area because of a lack of wells in less populated areas and also in some areas within the limits of the city of Tacoma. During an initial field inventory (September-December 2006), permission was obtained from selected well owners and synoptic water-level measurements were made in 229 wells; synoptic water-level measurements also were made in an additional 29 wells during a subsequent field inventory (February through April 2007) to address remaining data gaps (pl. 1). Water levels were measured on a monthly basis from March 2007 -September 2008 in 137 of the inventoried wells (pl. 1). Continuous water-level recorders were installed in six of the monthly monitoring wells (pl. 1).

Latitude and longitude locations were determined for each well using a Global Positioning System (GPS) receiver with a horizontal accuracy of one-tenth of a second (about $10 \mathrm{ft}$ ). Light Detection and Ranging (LiDAR) data were obtained through the Puget Sound LiDAR Consortium (http://pugetsoundlidar.ess.washington.edu/) and were used to determine the altitude of land surface at each well and to compute water-level altitudes. Vertical accuracy of the LiDAR data typically was $\pm 1 \mathrm{ft}$. Water level, reported as depth to water below land surface, was measured using a calibrated electric tape or graduated steel tape, both with a stated accuracy of $0.01 \mathrm{ft}$. There also is the potential for error in depth-to-water measurements associated with borehole deviation in sub-vertical wells. All water-level measurements were made by USGS personnel in accordance with standard techniques of the USGS (Drost, 2005). Water-level altitudes were determined by subtracting the measured depth-to-water below land surface from the LiDAR derived land-surface altitude at the well.

The spatial distribution of hydrogeologic data compiled solely from inventoried wells was insufficient to accurately characterize the spatial variability of hydrogeologic units across the study area. Therefore, an additional 206 wells with available drillers' logs were analyzed during this study to better represent the hydrogeologic framework in areas where inventory wells were lacking (pl. 1). Well locations and drillers' logs for these additional wells were obtained from the records of local public water supply systems, environmental consulting firms, and the USGS. Well information collected during the field inventory, monthly monitoring network, and construction of the hydrogeologic framework were entered into the USGS National Water Information System (NWIS) database and published in Justin and others (2009).

\section{Hydrogeology}

The hydrogeologic units in the Chambers-Clover Creek Watershed and vicinity were defined using a combination of geologic data including existing surficial geologic maps, well records with drillers' logs available from the Washington State Department of Ecology, and previous investigations by Robinson \& Noble, Inc., and others (2003) and Brown and Caldwell (1985).

The surficial hydrogeologic map for the study area (pl. 2; scale $1: 100,000)$ was produced by merging available digital surficial geologic maps (Schasse, 1987, scale 1:100,000, Walsh, 1987, scale 1:100,000) with scanned and digitized geologic maps by Troost (in press, scale 1:24,000) and Troost and others (in press, scale 1:24,000). Fifty geologic units delineated on these source maps were grouped into 11 hydrogeologic units based on similarities in lithology (grain size and sorting), hydrologic characteristics, and relative stratigraphic position (table 1). 


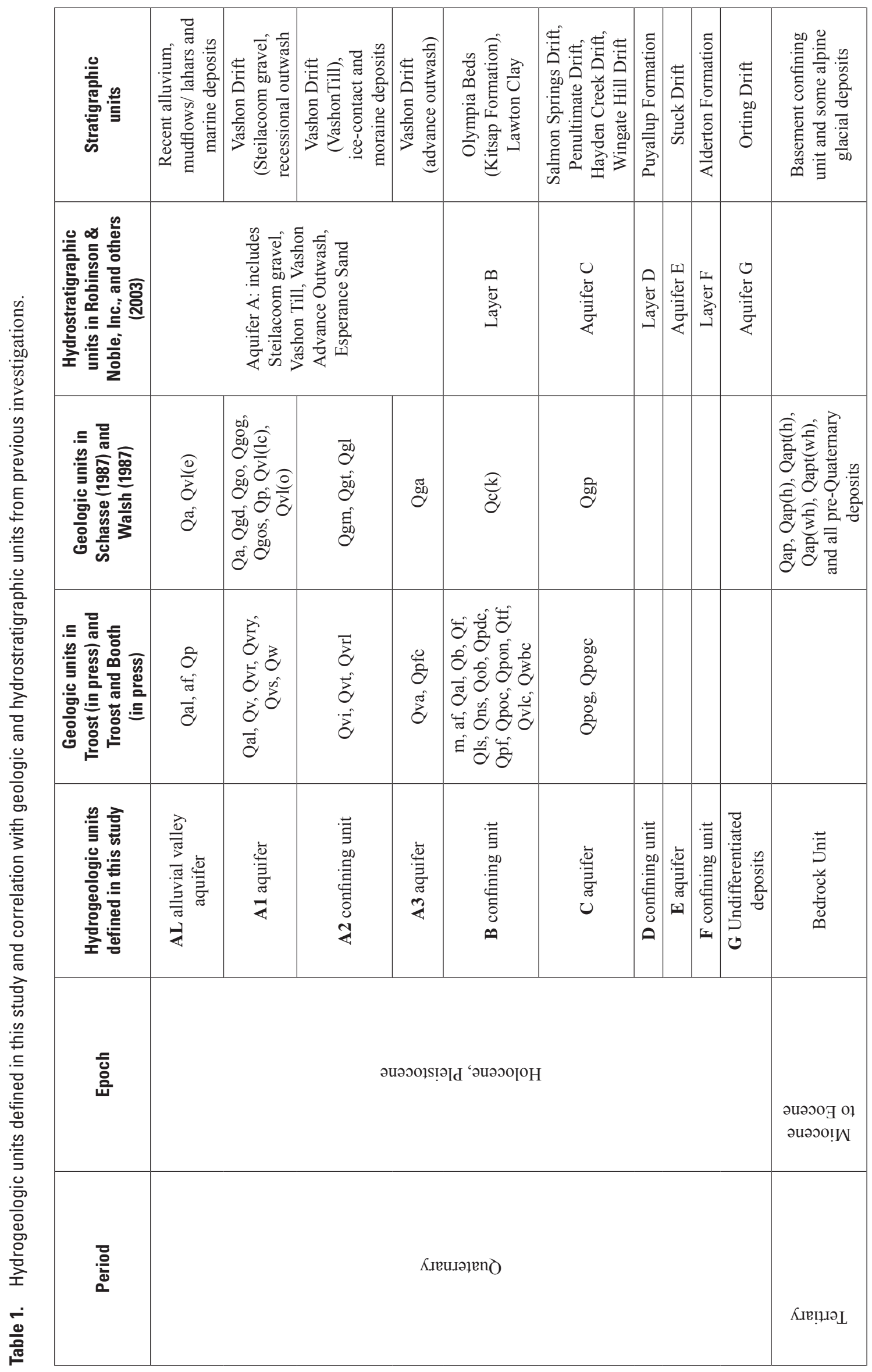


The surficial hydrogeologic map and lithologic data from more than 450 drillers' logs were used to construct more than 25 hydrogeologic sections using A-Prime Software's CrossView ${ }^{\mathrm{TM}}$ for ArcGIS ${ }^{\circledR}$ to identify and correlate the hydrogeologic units in the subsurface. Six representative hydrogeologic sections are shown on plate 2 . Hydrogeologic units were assigned to the various lithologic layers depicted in each well log. Hydrogeologic unit assignments were used to delineate the extent of each unit throughout the study area. The altitude of the unit top surface was interpolated in a Geographic Information System (GIS) at a $100 \mathrm{ft}$ interpolation grid cell size, using a method based on the Australian National University Digital Elevation Model (ANUDEM) procedure developed by Hutchinson (1989). Hydrogeologic unit top surfaces were constrained to a LiDAR-derived land-surface digital elevation model (DEM) where the unit cropped out. If part of a unit surface was interpolated above the top of an overlying unit then minimum thickness values for the overlying unit were used in the calculations to adjust the altitude of the top of the underlying unit where needed. This over-interpolation primarily occurred in areas where bedrock is overlain by relatively thin unconsolidated deposits (less than $100 \mathrm{ft}$ thick) or where there were large gaps in the data coverage. Unit thickness maps were created by using GIS to calculate the difference between the top of a unit and the interpolated top of the underlying unit(s). Residuals were calculated as the difference between the unit surface altitudes assigned for a specific well log and unit altitudes of the interpolated digital hydrogeologic surfaces at the location of the well. Statistics on the residuals were determined for each hydrogeologic unit, excluding the alluvial valley aquifer (AL) and the $\mathrm{A} 1$ aquifer, to provide a quantitative comparison between the specific well log data and the interpolated surfaces for the entire study area (table 2; fig. 2). Residuals commonly were within $\pm 1 \mathrm{ft}$ for all hydrogeologic units except the $\mathrm{A} 2$ confining and $\mathrm{A} 3$ aquifer units. Residuals typically were within $\pm 5 \mathrm{ft}$ for the $\mathrm{A} 2$ confining unit and within $\pm 4 \mathrm{ft}$ for the A3 aquifer unit. The absolute mean difference for all hydrogeologic units was within $5.5 \mathrm{ft}$.

Table 2. Statistics for interpolated digital hydrogeologic surfaces.

[C ount refers to number of wells used for interpolation of altitudes of digital hydrogeologic surfaces. A bsolute mean difference is average absolute difference between interpreted hydrogeologic unit altitudes taken from the well $\operatorname{logs}$ and altitudes of interpolated digital hydrogeologic surfaces. M inimum and maximum differences are those measured from interpreted hydrogeologic unit altitudes taken from the well logs and the altitudes of interpolated digital hydrogeologic surfaces]

\begin{tabular}{lcccc}
\hline \multirow{2}{*}{$\begin{array}{c}\text { Hydrogeologic } \\
\text { units }\end{array}$} & Count & \multicolumn{3}{c}{ Difference (feet) } \\
\cline { 3 - 5 } & & $\begin{array}{c}\text { Absolute } \\
\text { mean }\end{array}$ & Minimum & Maximum \\
\hline A2 confining unit & 328 & 2.43 & -66.68 & 24.49 \\
A3 aquifer & 308 & 1.83 & -32.57 & 32.82 \\
B confining unit & 189 & .86 & -11.16 & 18.70 \\
C aquifer & 209 & 1.24 & -32.37 & 33.50 \\
D confining unit & 111 & 1.65 & -22.46 & 33.66 \\
E aquifer & 79 & 1.90 & -28.39 & 49.53 \\
F confining unit & 58 & 5.27 & -78.79 & 96.34 \\
G undifferentiated & 44 & 5.48 & -75.33 & 86.38 \\
$\quad$ deposits & & & & \\
\hline
\end{tabular}



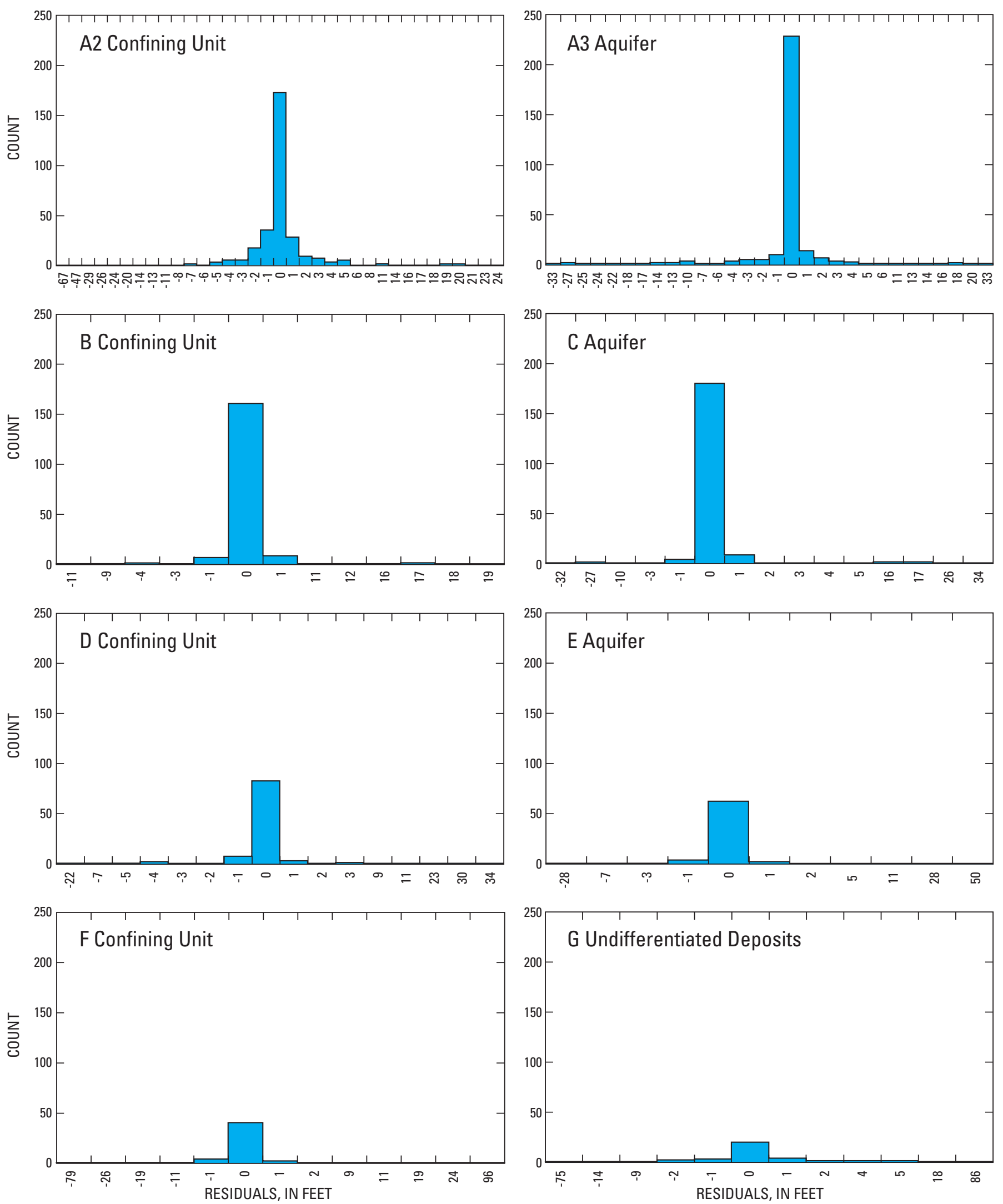

Figure 2. Residuals between hydrogeologic unit correlation altitudes and altitudes of interpolated digital hydrogeologic surfaces. 


\section{Streamflow}

Streamflow analysis in the study area included the evaluation of continuous streamflow data from 7 USGS streamflow-gaging stations and 2 streamflow measurements from 44 synoptic streamflow sites (pl. 1). These data were used to quantify the amount of surface water leaving the study area and to delineate gaining and losing stream reaches during low-flow conditions. Streamflow measurements at USGS streamflow-gaging stations and synoptic sites were made by USGS personnel, assisted by Pierce Conservation District Stream Team volunteers, using Price (pygmy or AA) and FlowTracker Handheld ADV® current velocity meters according to standard techniques of the USGS (Rantz, 1982). The USGS assigns an accuracy to streamflow measurements based on the equipment, character of the measurement section, number of observations, stability of stage, wind conditions, and the accuracy of depth and velocity measurements (Rantz, 1982, p. 179). Accuracy ratings of "good" indicate that the measurements are judged to be within 5 percent of true values, ratings of "fair" indicate that the measurements are judged to be within 8 percent of true values, and ratings of "poor" indicate that the measurements are judged not to be within 8 percent of true values (assumed to be within 11 percent of true values for this study). Estimates of streamflow were required at some sites where direct measurements could not be made because of sub-optimal flow conditions (low velocity, shallow water depth, or the presence of aquatic vegetation) or the need to visually estimate the streamflow value (lack of access to stream). Estimates of streamflow were based on (1) visual approximations of flow widths, depths, and velocities; (2) discharge measurements from nearby sites; or (3) discharge measurements from prior years. All estimated streamflow values were rated "poor." Additional streamflow data specific to streams in the study area was provided by state and county agencies, and military installations.

Numerous springs are present throughout the study area, and contribute to late-summer baseflow to streams and year-round groundwater discharge to the Puget Sound along shoreline bluffs. A field inventory of springs was not conducted during this investigation. Descriptions of spring locations and historical discharge provided by Blair (1929), Sceva and others (1955), Walters and Kimmel (1968), and Jones and others (1999) were evaluated.

\section{Hydrogeologic Framework}

This section describes the geology and hydrogeologic framework, which define the physical, lithologic, and hydrologic characteristics of the hydrogeologic units that compose the groundwater-flow system in the study area.
An understanding of these characteristics is important in determining the occurrence, movement, and availability of groundwater in the aquifer system, and the exchange of water between the aquifer system and surface-water features.

\section{Geologic Setting}

A brief summary of major geologic events in the study area is given below and is based on the work of Walters and Kimmel (1968), Jones (1999), and Borden and Troost (2001). Plate tectonics and glacial processes are the two major forces that have shaped the present-day Puget Lowland. The most recent advance and retreat of continental glaciers in the Pleistocene epoch of the Quaternary Period left behind more than $3,000 \mathrm{ft}$ of unconsolidated deposits in the lowland and about $2,000 \mathrm{ft}$ of deposits in the study area. These deposits form the hydrogeologic units defined in this study and will be the focus of the remaining discussion.

The Puget Lobe of the Cordilleran ice sheet has advanced and retreated several times into the Puget Lowland from the mountains of British Columbia since the beginning of the Quaternary and has left behind a complex sequence of alternating glacial and interglacial sediments. The Vashon Stade of the Fraser Glaciation was the most recent and extensive of the major advances. Because every glacial advance partially removes and reworks deposits from earlier glaciations, deposits from the Vashon Glacier offer the most complete glacial drift sequence. Glacial deposits typically contain (in order of deposition) advance outwash sand and gravels; glacial till (hard and poorly sorted mixture of clay, silt, sand, and gravel) and ice-contact deposits, and recessional outwash sand and gravels at the top of the sequence.

Each major glacial interval is followed by an extended interglacial period where fluvial, lacustrine, bog, and marsh deposition dominate. Interglacial deposits typically consist of clay, silt, or discontinuous lenses of sand and gravel or peat. Underlying these unconsolidated glacial and interglacial deposits are Tertiary bedrock units consisting primarily of sedimentary claystone, siltstone, sandstone, beds of coal, and volcanic rocks (Walters and Kimmel, 1968). Alpine glacial deposits are locally present in areas of exposed bedrock.

\section{Hydrogeologic Units}

Geologic units were grouped into hydrogeologic units consisting of aquifers and confining units (table 1) based on similarities in lithology (grain size and sorting), hydrologic characteristics, and relative stratigraphic position. The hydrogeologic units defined in this study are based on units defined by previous investigations in the study area (Brown and Caldwell, 1985; Robinson \& Noble, Inc., and others 2003). Differences between units defined in this study and 
previous investigations include (1) the differentiation of unit A into four units for this study (table 1); and (2) the discontinued use of hydrostratigraphic units in which all glacial deposits are characterized as aquifers and interglacial deposits are characterized as confining units, in favor of the use of hydrogeologic units in which aquifers and confining unit designations are based on the lithologic and hydrologic characteristics of deposits regardless of depositional environment (for example, an aquifer unit may consist of both glacial outwash and interglacial alluvial deposits). Hydrogeologic units defined in this study are not directly comparable (unit extent or thickness) to previously published units.

An aquifer is saturated geologic material that is sufficiently permeable to yield water in significant quantities to a well or spring, whereas a confining unit has low permeability that restricts the movement of groundwater and limits the usefulness of the unit as a water source. Unconfined and confined aquifer conditions are present in the study area. Unconfined or "water-table" conditions occur when the upper surface of the saturated zone is at atmospheric pressure and is free to rise and decline in response to changes in groundwater recharge and discharge. The position of the water table is represented by water levels in shallow wells. Confined or "artesian" conditions occur when an aquifer is overlain by a less permeable confining unit and the groundwater is under pressure greater than atmospheric pressure. Water in a tightly cased well drilled into a confined aquifer will rise to a height corresponding to the hydraulic head (the potentiometric surface) of the confined groundwater at that location. If the hydraulic head is sufficient to raise the water above land surface, the well will flow and is called a flowing artesian well. The potentiometric surface in a confined aquifer is analogous to the water table in an unconfined aquifer. The potentiometric surface fluctuates in response to changes in recharge and discharge, however, unlike the water table, the potentiometric surface is higher in altitude than the top of the confined aquifer.

Glacial deposits generally are heterogeneous, and although a glacial aquifer may be composed primarily of sand or gravel, it may locally contain varying amounts of clay or silt. Conversely, a confining layer composed predominantly of silt or clay may contain local lenses of coarse material. These small-scale variations in lithology may influence the occurrence and movement of groundwater at a scale that likely is too small to be adequately represented by the hydrogeologic framework constructed for this study. In the Puget Lowland, aquifers consist primarily of glacial outwash but also may include coarse-grained interglacial deposits. The confining units consist primarily of fine-grained interglacial deposits but also may include glacial till or glaciolacustrine deposits. Unconsolidated glacial and interglacial aquifer and confining units are underlain by low-permeability Tertiary bedrock units, described as the basement confining unit in Jones (1999). Eleven hydrogeologic units are recognized in the study area (table 1 and pl. 2) and their lithologic and hydrologic characteristics are described below.

AL alluvial valley aquifer.-The AL alluvial valley aquifer is present throughout the Puyallup, Carbon, and Nisqually River valleys and along Ohop Creek (fig. 3), and includes alluvial (Qal and Qa), mudflow (Qvl (e)), and tide flat and artificial fill (Qp and af) deposits. This hydrogeologic unit primarily consists of alluvial silt, sand, and gravel deposits that closely follow Holocene river valleys. Because of the spatial variability of stream sediments and inclusion of some mudflow and lahar deposits, the lithologic character of this unit is quite heterogeneous and varies greatly with depth. The unit generally is less than $100 \mathrm{ft}$ thick along the Nisqually River, Ohop Creek, and Carbon River, but exceeds $250 \mathrm{ft}$ along the Puyallup River as it nears Commencement Bay. Groundwater in this aquifer generally is unconfined; however, confined conditions may occur locally beneath mudflow deposits.

A1 aquifer.-The A1 aquifer is present at land surface throughout much of the study area (pl.2) and primarily is composed of Vashon recessional outwash (Qvr) deposits of the Fraser Glaciation. These deposits consist of stratified silt, sand, and gravel deposited by large meltwater streams formed during the northward retreat of the Puget Lobe. A subdivision of Qvr deposits known as the Steilacoom Gravels (Qvs) are found in successive outwash channels formed by streamflow originating from proglacial Lake Puyallup (Walters and Kimmel, 1968). These gravels are characterized by their consistency and coarseness over a large part of the study area. Several other geologic units, including wetland $(\mathrm{Qw})$, peat (Qp), Osceola mudflow (Qvl(o)), and undifferentiated Vashon drift $(\mathrm{Qv})$ deposits, were included in the A1 aquifer unit because of their limited areal extent and/or close proximity to other recessional deposits. Some alluvial deposits (Qa and Qal) that were not connected with river valleys also were grouped with the A1 aquifer unit. The thickness of the A1 aquifer typically ranges from a thin veneer of less than $35 \mathrm{ft}$ to about $150 \mathrm{ft}$, but can locally exceed $200 \mathrm{ft}$ where underlying units are not present (fig. 4). Groundwater generally is unconfined in this aquifer.

A2 confining unit.- The A2 confining unit is present at land surface throughout the study area (pl. 2) and is composed primarily of Vashon till (Qvt) and lesser amounts of ice-contact (Qvi), moraine (Qgm), and fine-grained glaciolacustrine (Qvrl and Qgl) deposits. This low-permeability unit consists of various proportions of clay, silt, sand, and gravel, with locally occurring sand and gravel lenses capable of providing water for domestic use. The thickness of the $\mathrm{A} 2$ confining unit averages about $60 \mathrm{ft}$ but varies spatially from a thin veneer to about $150 \mathrm{ft}$ (fig. 5). In a few small areas, the thickness exceeds $200 \mathrm{ft}$. 


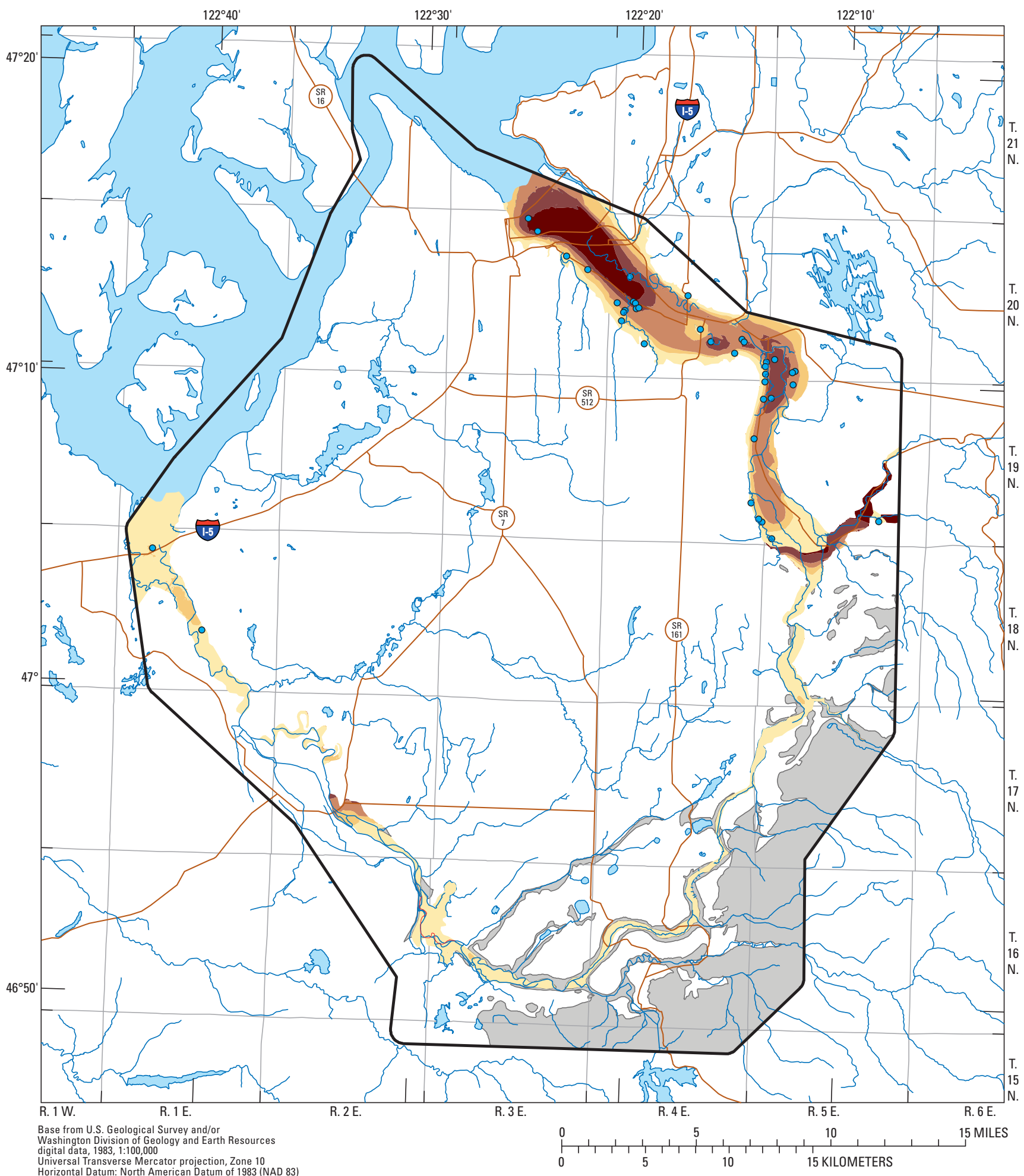

EXPLANATION

Extent and thickness of
AL alluvial valley aquifer, in feet
\begin{tabular}{|c|c|}
\hline & -70 \\
\hline & $176-250$ \\
$71-125$ & $251-425$ \\
$126-175$ &
\end{tabular}

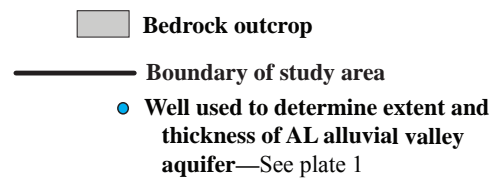

Figure 3. Extent and thickness of AL alluvial valley aquifer in Chambers-Clover Creek Watershed and vicinity, Washington. 


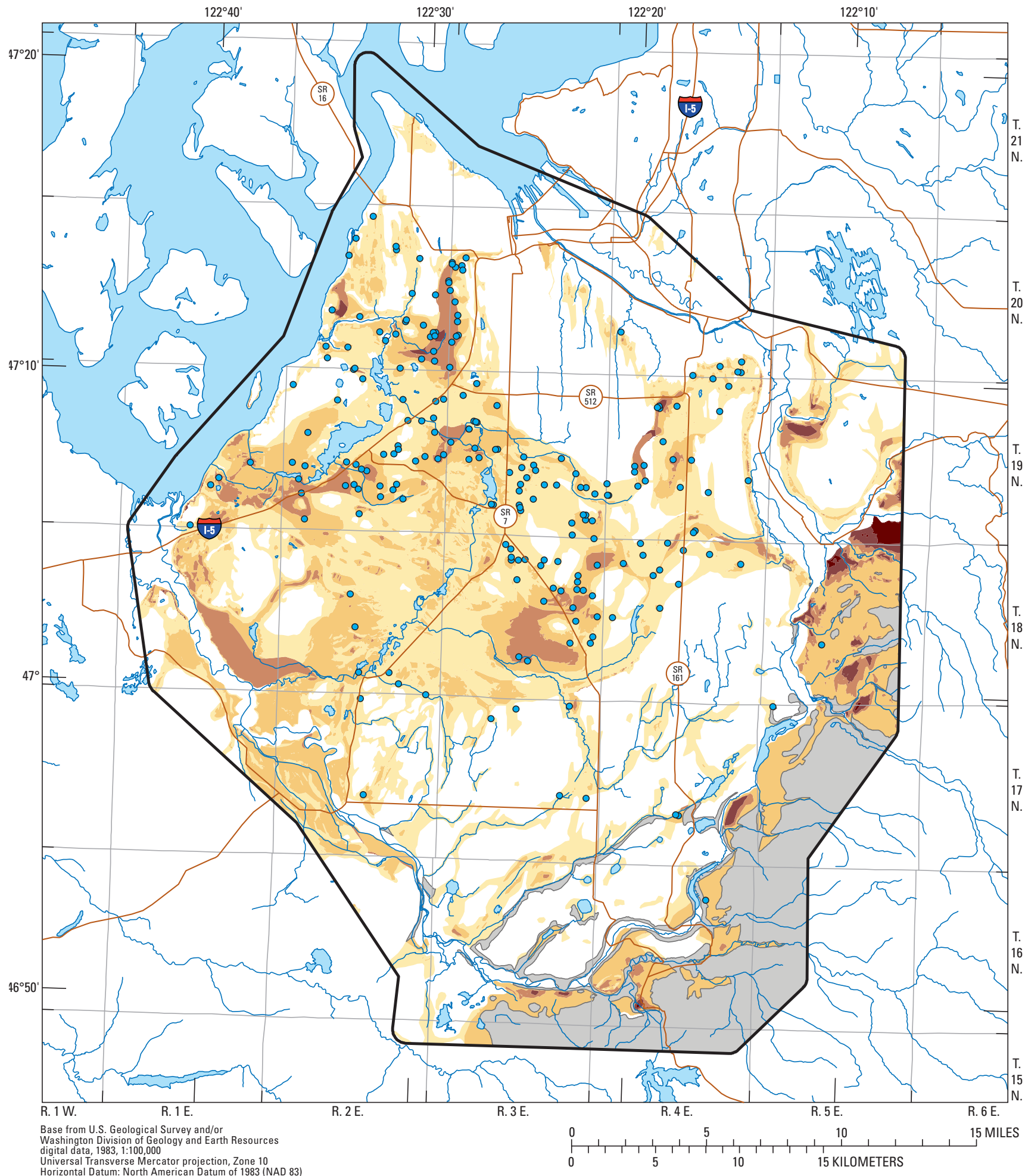
Horizontal Datum: North American Datum of 1983 (NAD 83)

EXPLANATION
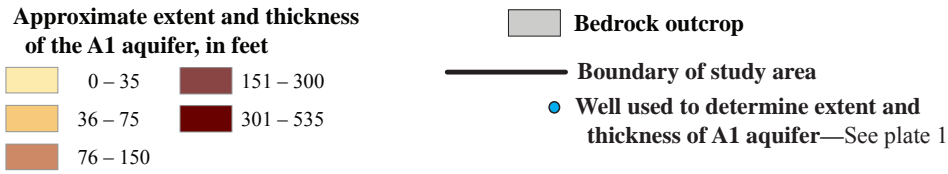

Figure 4. Extent and thickness of A1 aquifer in Chambers-Clover Creek Watershed and vicinity, Washington. 


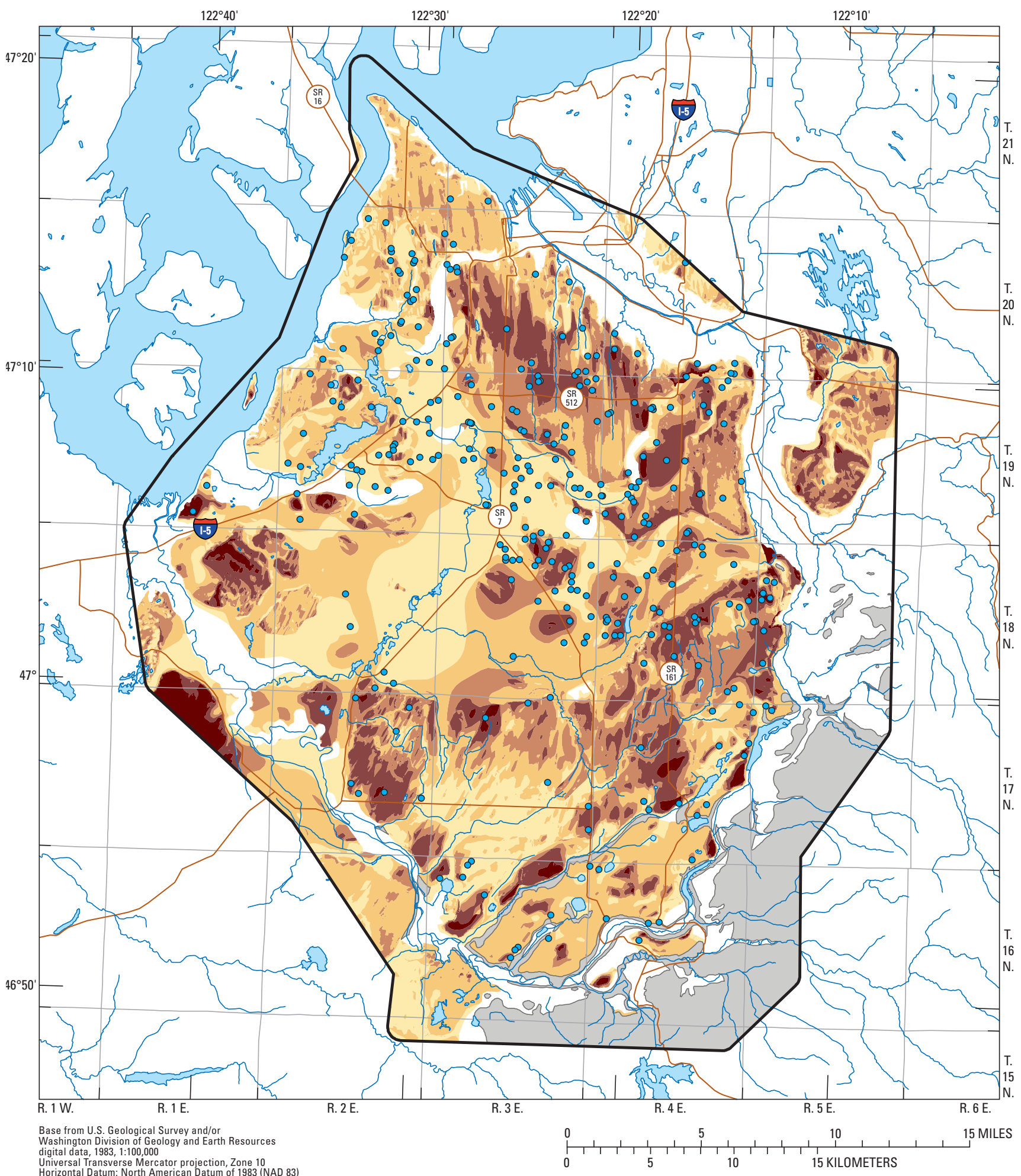

EXPLANATION
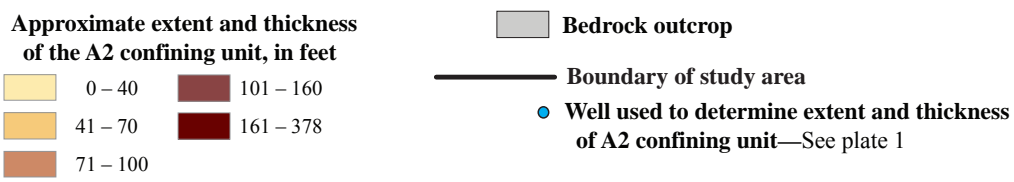

Figure 5. Extent and thickness of A2 confining unit in Chambers-Clover Creek Watershed and vicinity, Washington. 
A 3 aquifer.-The $\mathrm{A} 3$ aquifer is present in the subsurface throughout most of the study area (fig. 6), with surface exposures limited to a few steep slopes and along the walls of deeply incised stream valleys and coastal bluffs (pl. 2). The unit primarily is composed of Vashon advance outwash (Qva) and small amounts of Pre-Fraser coarse-grained non-glacial deposits (Qpfc), and consists of well-sorted sand or sand and gravel, with lenses of silt and clay. The average thickness of the $\mathrm{A} 3$ aquifer is $75 \mathrm{ft}$, but locally exceeds $160 \mathrm{ft}$ (ig. 6 ). Groundwater in this aquifer generally is confined by the overlying Vashon till; however, unconfined conditions may occur locally where it is not fully saturated or is exposed at land surface.

B confining unit.-The B confining unit is present in the subsurface throughout central and northern parts of the study area (fig. 7) with surface exposures limited to areas along coastal bluffs (pl. 2). This low-permeability unit primarily is composed of fine-grained silts and clays (Olympia beds-Qob) deposited during the Olympia interglacial and glaciolacustrine clays deposited during early Vashon (Lawton clay-Qvlc). The $\mathrm{B}$ confining unit also includes several additional geologic units (table 1) that are laterally continuous with the Qob and Qvlc deposits and/or have similar lithologic characteristics. The average thickness of the B confining unit is about $55 \mathrm{ft}$, but locally exceeds $200 \mathrm{ft}$ (fig. 7).

C aquifer.-The $\mathrm{C}$ aquifer, often referred to as the sea-level aquifer because of its coincident altitude, is present in the subsurface throughout central and northern parts of the study area (fig. 8), with surface exposures limited to a few steep slopes and along the walls of deeply incised stream valleys (pl. 2). The unit primarily is composed of pre-Olympia glacial drift deposits locally referred to as the Salmon Springs Drift (Walters and Kimmel, 1968) and consists of sand and gravel, with minor lenses of silt, clay, and till. The average thickness of the $\mathrm{C}$ aquifer unit is about $105 \mathrm{ft}$, but locally exceeds $200 \mathrm{ft}$ (fig. 8). Groundwater in this aquifer generally is confined by the overlying B confining unit. However, unconfined conditions may occur locally where no overlying confining unit is present (figs. 5 and 7), or in places where the unconfined unit is not fully saturated.

D confining unit.- The D confining unit is present in the subsurface throughout central and northern parts of the study area (fig. 9); is not present at land surface in the study area, except under Puget Sound (pl. 2); and is recognized only in drillers' logs. This low-permeability unit most likely correlates with deposits from the Puyallup Interglacial and consists of alluvial and lacustrine sand, silt, and clay deposits, and occasional deposits of volcanic ash. The average thickness of the D confining unit is about $100 \mathrm{ft}$, but locally exceeds $200 \mathrm{ft}$ (fig. 9). Most notably, an area of significant thickness occurs along the western edge of the study area south of Chambers Creek where unit D is present in place of Units $\mathrm{C}$ or $\mathrm{E}$ (or both). Brown and Caldwell (1985) and Noble (1990) describe this feature as being a probable ancestral Narrows channel that was filled in with fine-grained lacustrine deposits.

E aquifer.-The E aquifer is present in the subsurface throughout central and northern parts of the study area (fig. 10); is not present at land surface in the study area, except under Puget Sound (pl. 2); and is recognized only in drillers' logs. This unit most likely correlates with deposits of the Stuck Drift; the third recognized glaciation of the southern Puget Sound area (Walters and Kimmel, 1968), and consists primarily of silt, sand, and gravel, with discontinuous till and lacustrine deposits. The thickness of the E aquifer typically ranges from a thin veneer to about $120 \mathrm{ft}$ but exceeds $200 \mathrm{ft}$ in places where underlying units are not present (ig. 10). Groundwater in this aquifer is confined by the overlying D confining unit.

F confining unit.-The F confining unit is present in the subsurface throughout central and northern parts of the study area (fig. 11); is not present at land surface in the study area, except under Puget Sound (pl. 2); and is recognized only in drillers' logs. This low-permeability unit most likely correlates with deposits of the Alderton Formation and primarily consists of silt and clay, with minor lenses of sand and gravel. Limited well data indicate that thicknesses typically range from 50 to $200 \mathrm{ft}$; however, thicknesses exceed $300 \mathrm{ft}$ in places (fig. 11).

G undifferentiated deposits. - The undifferentiated deposits assigned to unit $\mathrm{G}$ primarily consist of stratified sand and gravel, with discontinuous layers of till. Few wells in the study area fully penetrate these unconsolidated deposits down to the bedrock surface, and little is known about the spatial distribution of water-bearing and non-water-bearing sediments in the deeper parts of the unconsolidated sequence (Brown and Caldwell, 1985). The uppermost part of unit G likely correlates to the Orting drift, the oldest identified Pleistocene glaciation in the Puget Sound area (Walters and Kimmel, 1968). Several public water-supply systems in the study area withdraw water from the upper part of the unit. Thickness estimates for this unit (fig. 12) were computed by subtracting the top of bedrock from the top of unit $\mathrm{G}$.

Bedrock unit.-The bedrock unit crops out in the foothills along the southern and southeastern margin of the study area. This low-permeability unit consists of sedimentary claystone, siltstone, sandstone, beds of coal, and volcanic rocks. Alpine glacial deposits (primarily clay and silt) also were included in this unit where they are laterally continuous with and have similar lithologies to bedrock. 


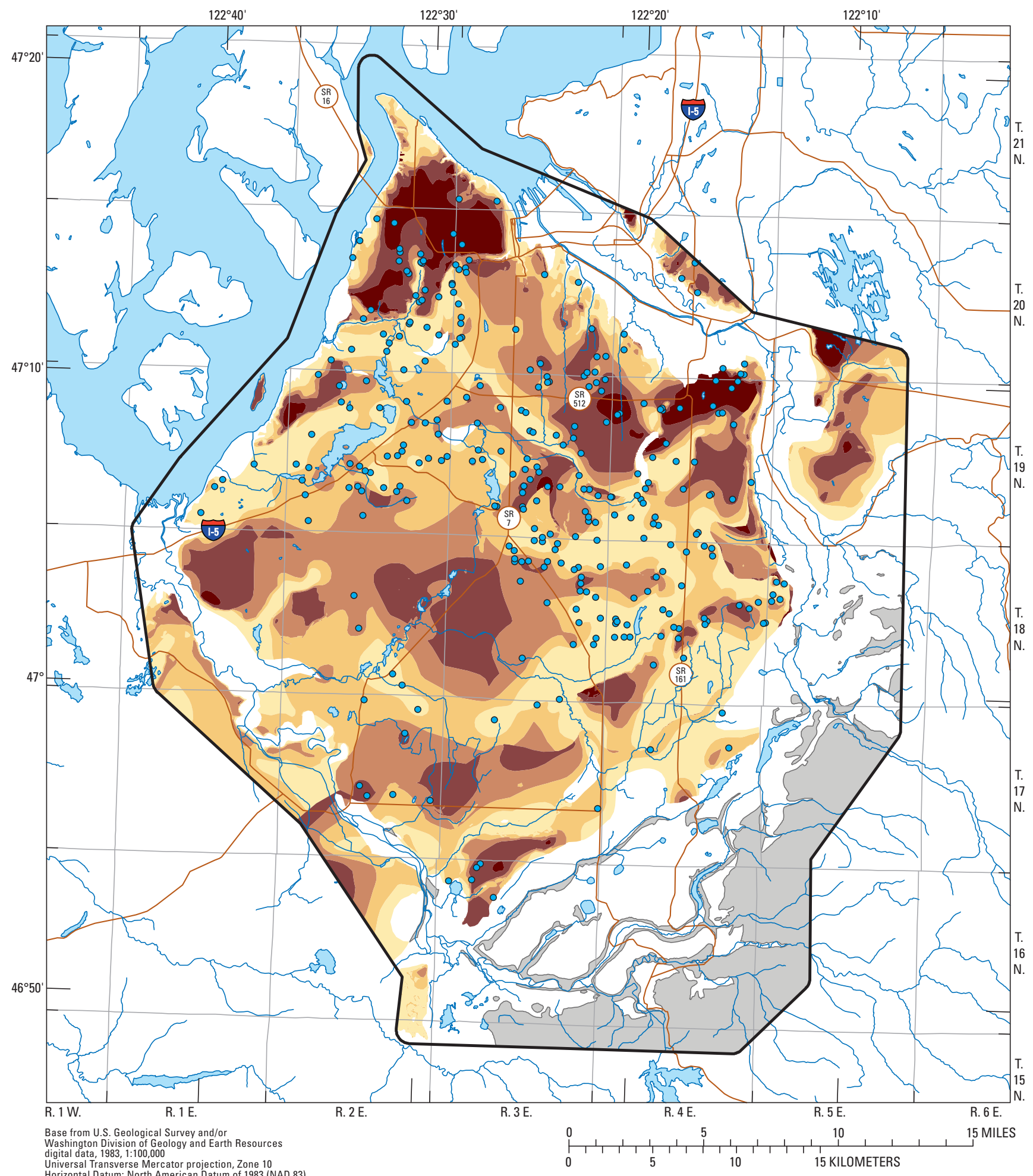

Universal Transverse Mercator projection, Zone 10
Horizontal Datum: North American Datum of 1983 (NAD 83)

EXPLANATION
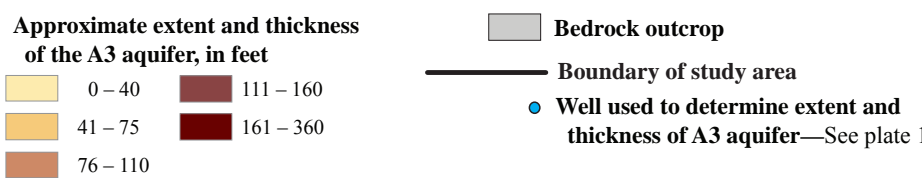

Figure 6. Extent and thickness of $\mathrm{A} 3$ aquifer in Chambers-Clover Creek Watershed and vicinity, Washington. 


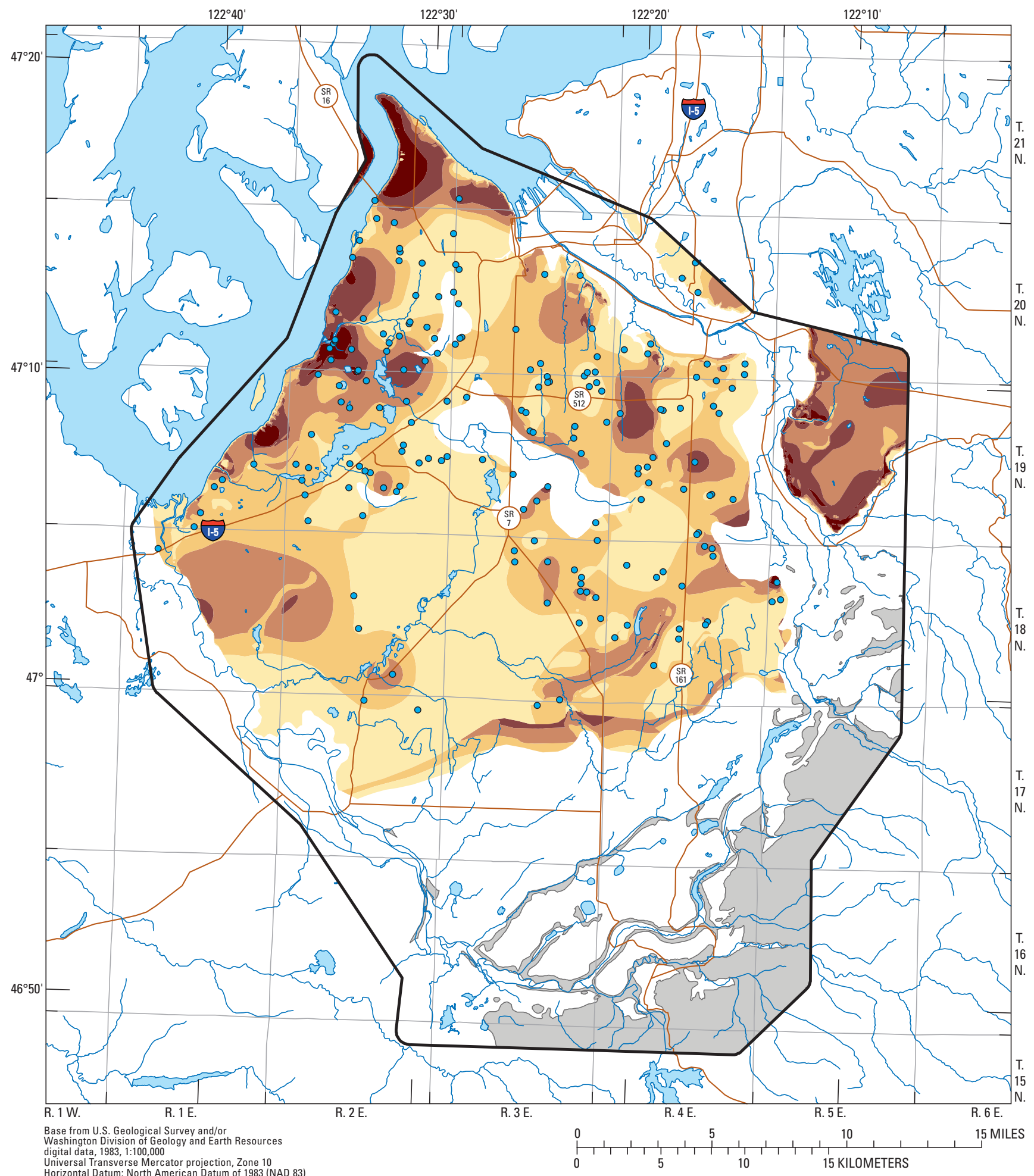

Horizontal Datum: North American Datum of 1983 (NAD 83)

EXPLANATION

A pproximate extent and thickness of the $B$ confining unit, in feet

$\square \quad 0-35$

$36-70$

$111-165$

$166-349$

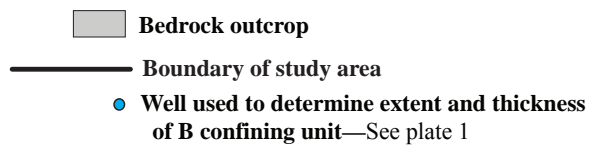

of B confining unit- See plate 1

Figure 7. Extent and thickness of B confining unit in Chambers-Clover Creek Watershed and vicinity, Washington. 


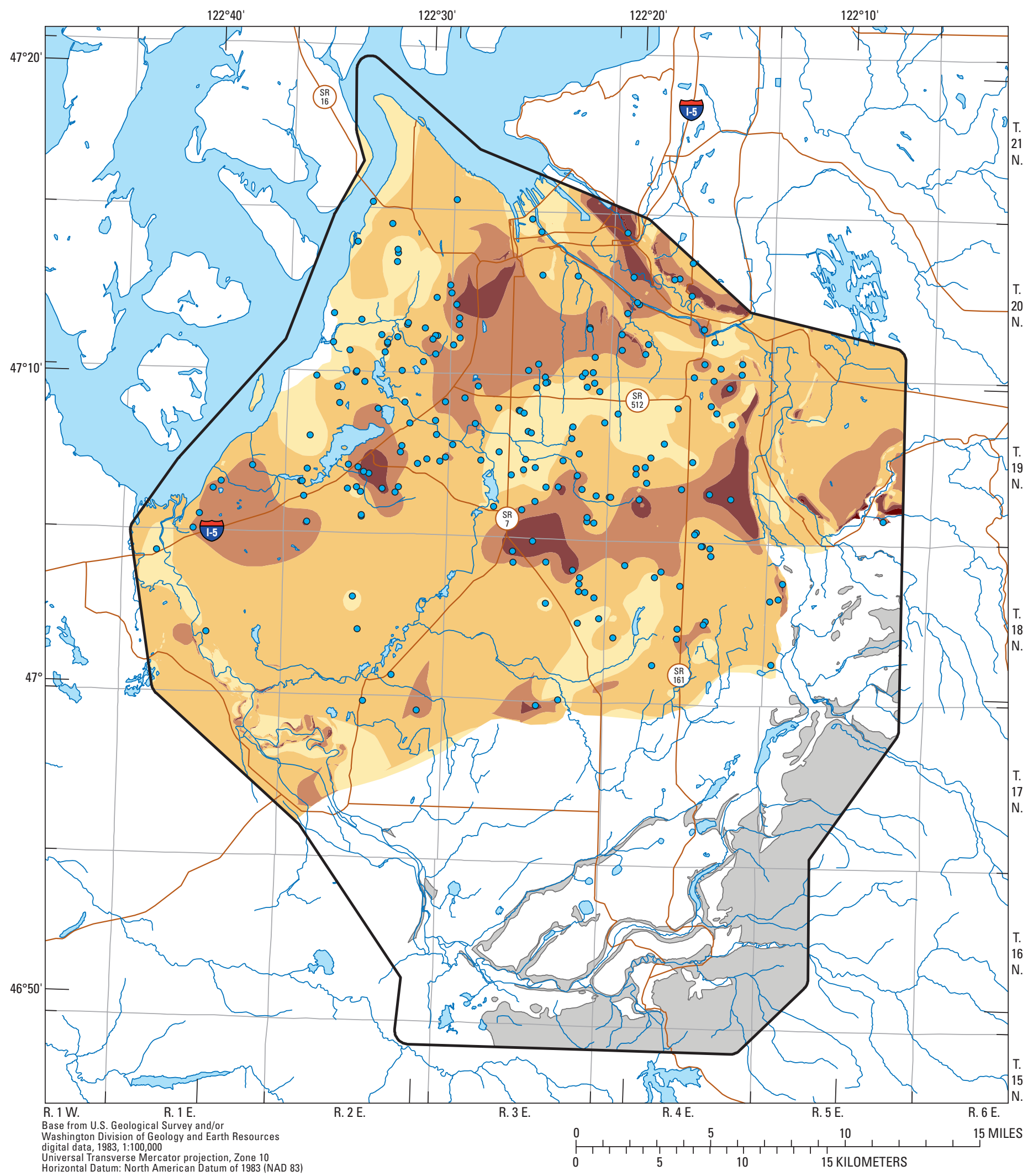

EXPLANATION

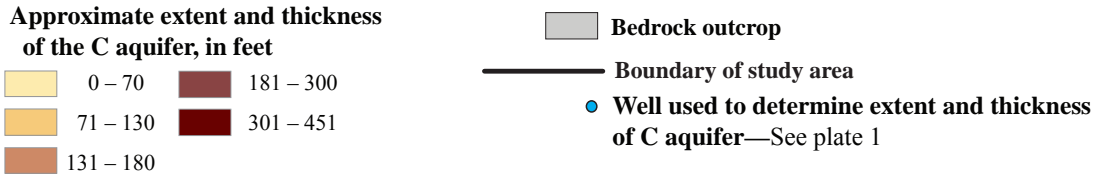

Figure 8. Extent and thickness of $\mathrm{C}$ aquifer in Chambers-Clover Creek Watershed and vicinity, Washington. 


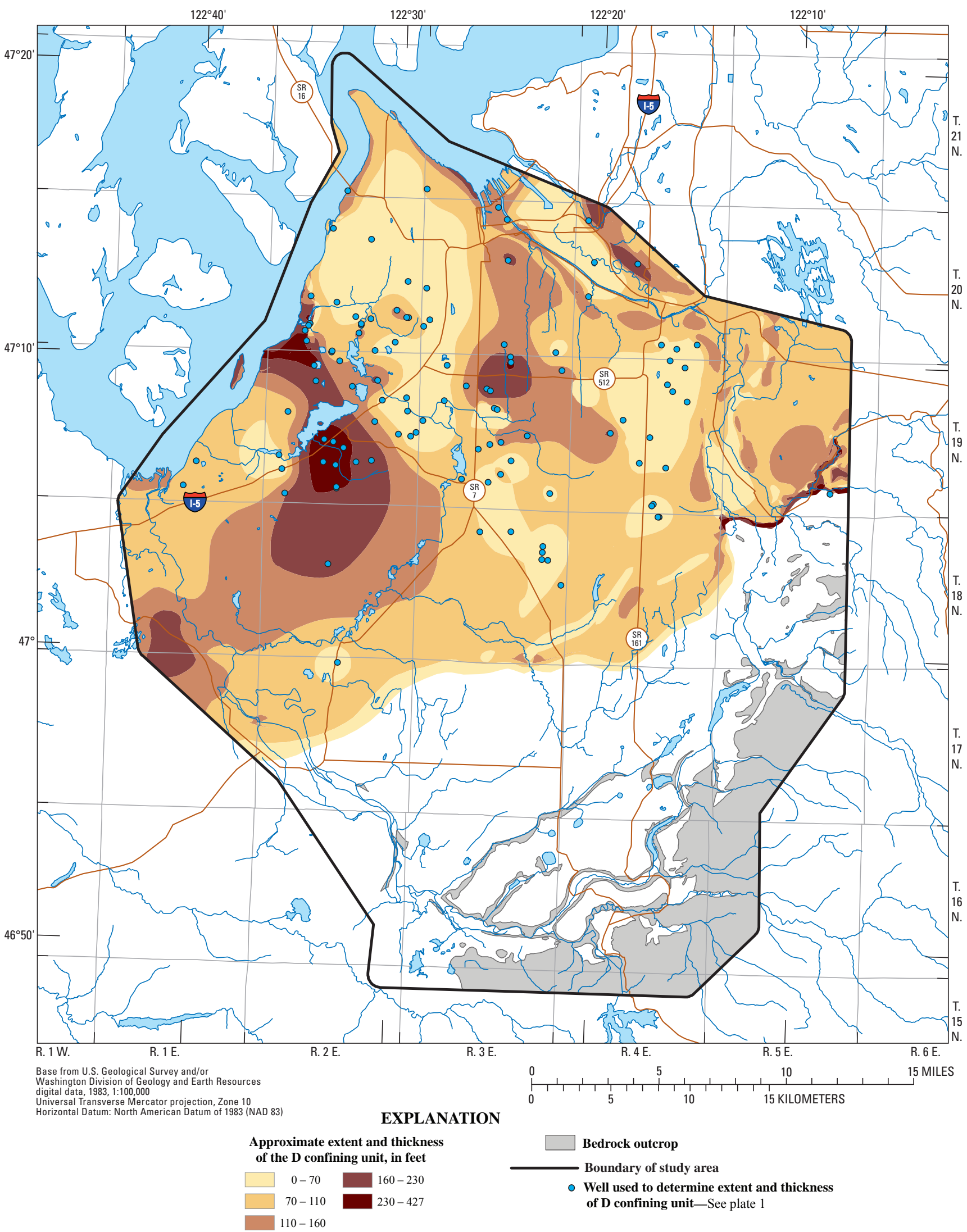

Figure 9. Extent and thickness of $D$ confining unit in Chambers-Clover Creek Watershed and vicinity, Washington. 


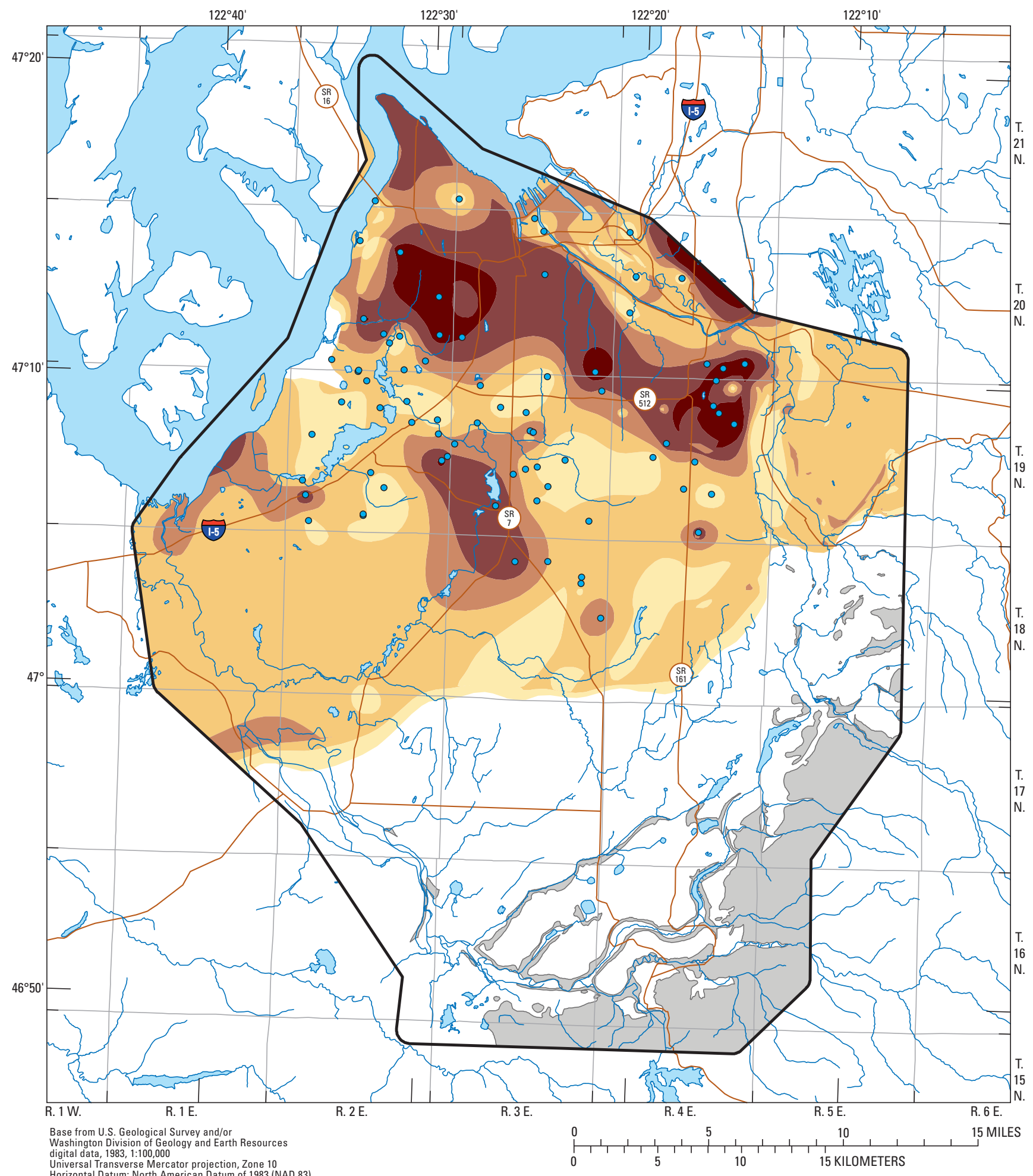

EXPLANATION
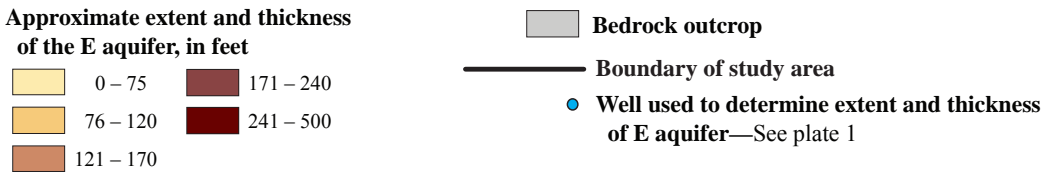

Figure 10. Extent and thickness of $\mathrm{E}$ aquifer in Chambers-Clover Creek Watershed and vicinity, Washington. 


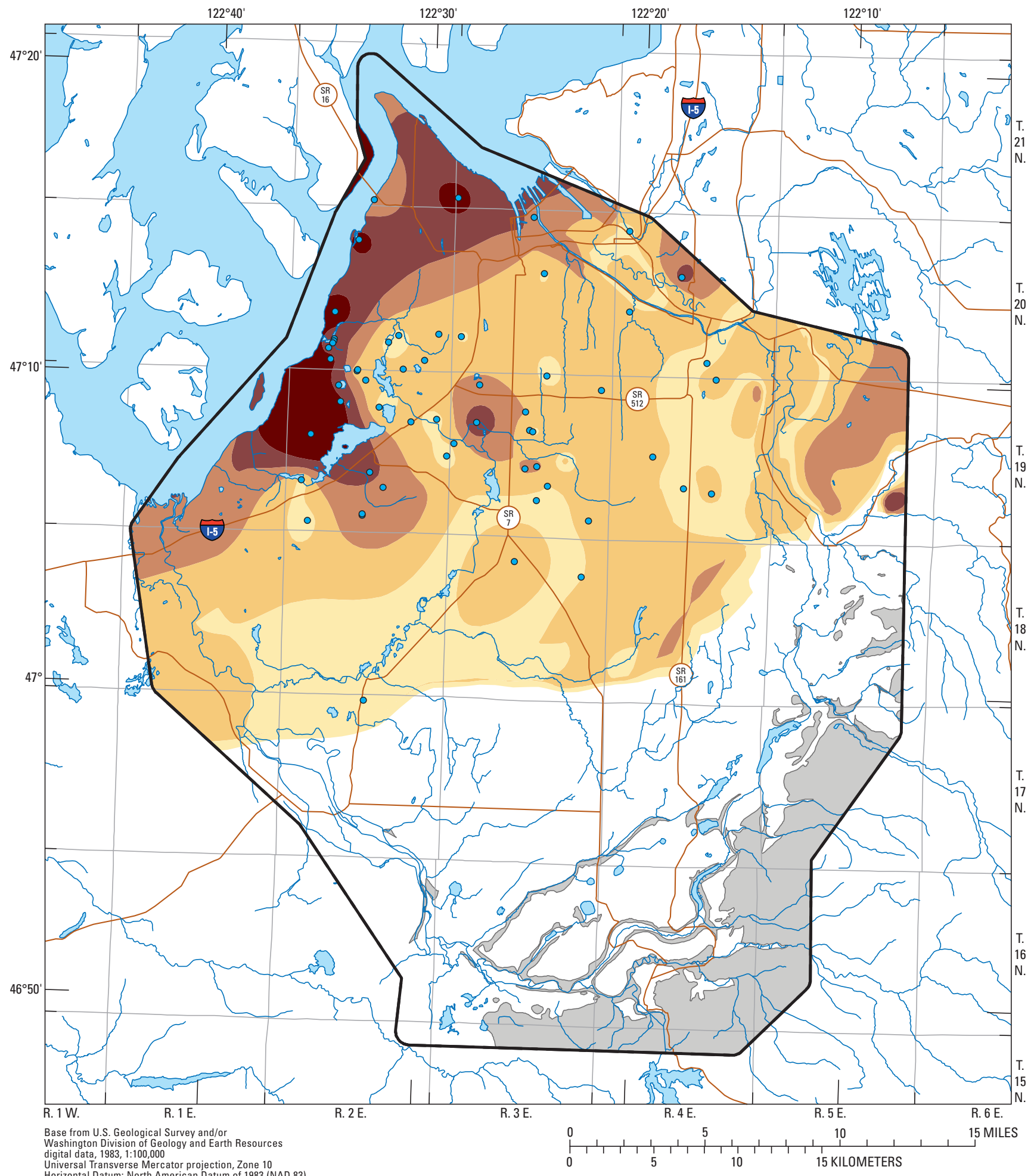

EXPLANATION
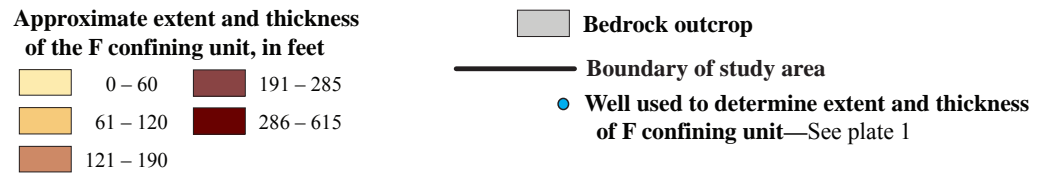

Figure 11. Extent and thickness of F confining unit in Chambers-Clover Creek Watershed and vicinity, Washington. 


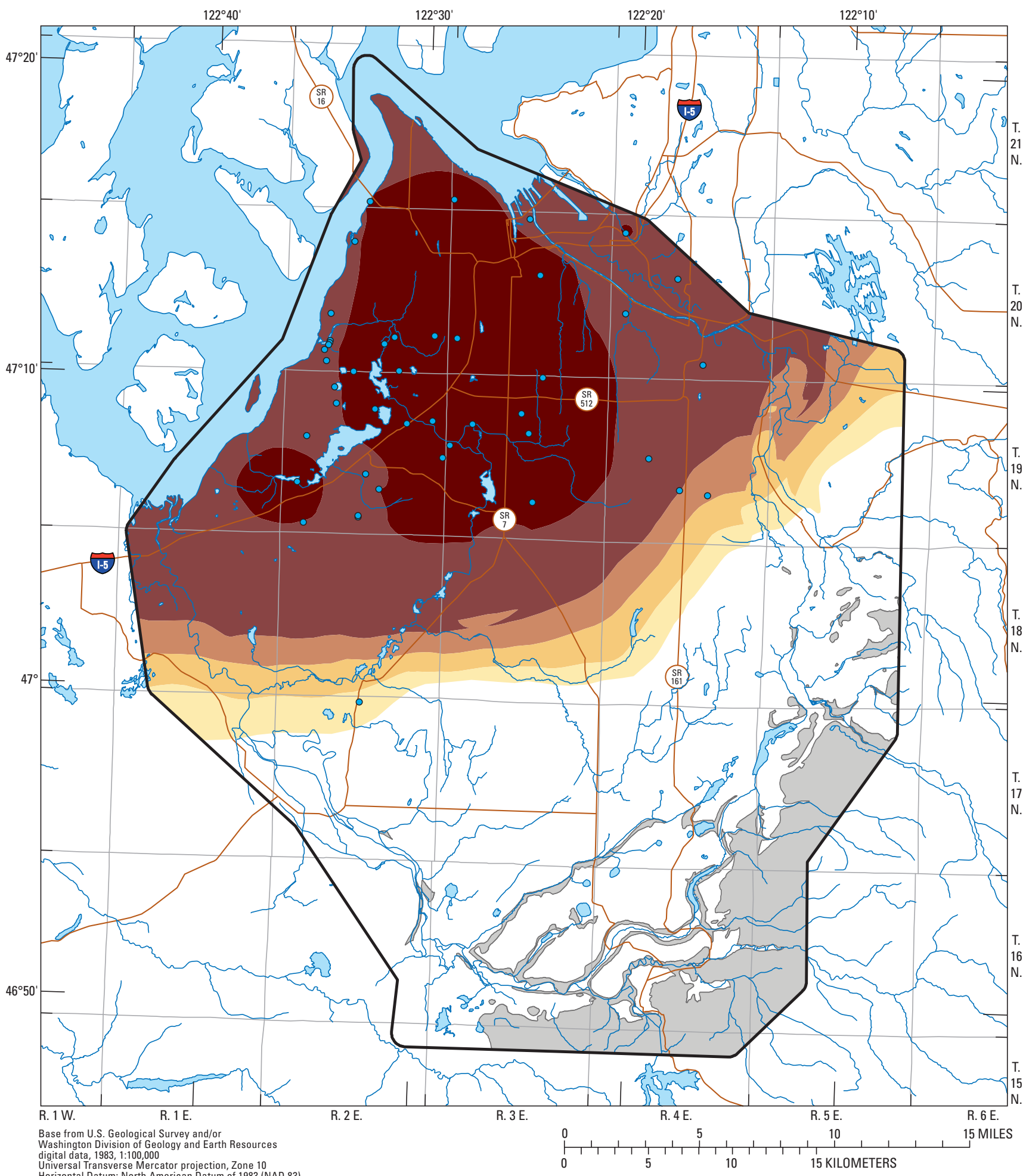

Universal Transverse Mercator projection, Zone 10
Horizontal Datum: North American Datum of 1983 (NAD 83)

EXPLANATION

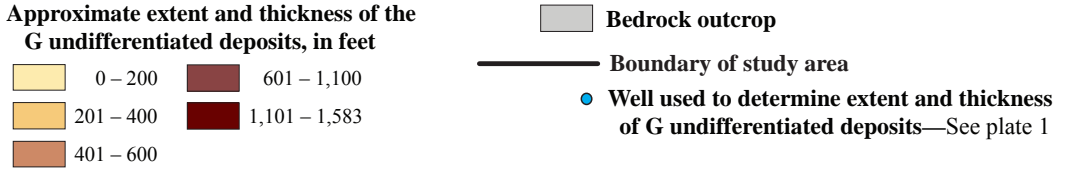

Figure 12. Extent and thickness of $\mathrm{G}$ undifferentiated deposits in Chambers-Clover Creek Watershed and vicinity, Washington. 


\section{Hydraulic Conductivity}

Hydraulic conductivity is a measure of a material's ability to transmit water, and in unconsolidated sediment, it is dependent on the size, shape, distribution, and packing of the particles. Because these physical characteristics vary greatly within the glacial deposits of the study area, hydraulic conductivity values also are highly variable. Estimates of the magnitude and distribution of hydraulic conductivity were used to develop an understanding of groundwater movement and availability in the hydrogeologic units.

Horizontal hydraulic conductivity was estimated for the hydrogeologic units using specific-capacity data from drillers' logs, and results of aquifer tests conducted by Robinson \& Noble Inc. (Burt Clothier, written commun., 2009) and Carr/Associates Inc. (1988). Specific-capacity data (water-level drawdown measured after pumping a well for a specified period of time) were compiled and analyzed for wells that had a drillers' log containing discharge rate, time of pumping, drawdown, static water level, well-construction data, and lithologic descriptions. Wells that met the above criterion included 142 wells constructed with a screened or perforated open interval and 18 wells constructed with an open-ended well casing. Aquifer tests results were available for 43 public water-supply wells.

Two sets of equations were used to estimate hydraulic conductivity from specific-capacity data, depending on well construction. For data from wells with a screened or perforated open interval, the modified Theis equation (Ferris and others, 1962) was first used to estimate transmissivity of the pumped interval. Transmissivity is the product of horizontal hydraulic conductivity and thickness of the part of the hydrogeologic unit supplying water to the well. The modified equation is

$$
s=\frac{Q}{4 \pi T} \ln \frac{2.25 T t}{r^{2} S},
$$

where

$s$ is drawdown in the well, in feet;

$Q$ is discharge, or pumping rate, of the well, in cubic feet per day;

$T$ is transmissivity of the hydrogeologic unit, in days;

$t$ is length of time the well was pumped, in days;

$r$ is radius of well, in feet; and

$S$ is storage coefficient, a dimensionless number, assumed to be 0.0001 for confined units and 0.1 for unconfined units.

Assumptions for using equation 1 are that (1) aquifers are homogeneous, isotropic, and infinite in extent; (2) wells fully penetrate the aquifer; (3) flow to the well is horizontal; and (4) water is released from storage instantaneously.

Additionally, for unconfined aquifers, drawdown is assumed to be small in relation to the saturated thickness of the aquifer.
Although most of the assumptions are not precisely met, the field conditions in the study area approximate most of the assumptions and the calculated hydraulic conductivities are reasonable estimates.

A computer program was used to solve equation 1 for transmissivity $(T)$ using Newton's iterative method (Carnahan and others, 1969). The difference in computed transmissivity between using storage coefficient values of 0.1 and 0.0001 is a factor of only about 2 . Next, the following equation was used to calculate horizontal hydraulic conductivity:

$$
K_{h}=\frac{T}{b},
$$

$$
\begin{aligned}
& \text { where } \\
& K_{h} \text { is horizontal hydraulic conductivity of the } \\
& \text { geologic material in the vicinity of the } \\
& \text { well opening, in feet per day; and } \\
& b \text { is thickness of the geologic material, in feet, } \\
& \text { approximated using the length of the open } \\
& \text { interval as reported in the drillers' report. }
\end{aligned}
$$

The use of the length of a well's open interval for $b$ may overestimate values of $K_{h}$ because the equations assume that all water flows horizontally within a layer of this thickness. Although some of the flow will be outside this region, the amount can be expected to be small (for short-duration pumping events) because in most sedimentary deposits, vertical flow is inhibited by layering.

For data from wells having only an open-ended well casing rather than a screened or perforated interval, a second equation was used to estimate hydraulic conductivities. Bear (1979) provides an equation for hemispherical flow to an open-ended well just penetrating a hydrogeologic unit. When modified for spherical flow to an open-ended well within a unit, the equation becomes

$$
K_{h}=\frac{Q}{4 \pi s r} .
$$

This equation is based on the assumption that horizontal and vertical hydraulic conductivities are equal, which is not likely for the deposits in the study area. Because vertical conductivities generally are lower than horizontal in these deposits, the result of violating this assumption is an underestimate of $K_{h}$ by an unknown amount.

Horizontal hydraulic conductivities were calculated for wells with available specific-capacity data, and statistical summaries were prepared by hydrogeologic unit (table 3 ). Horizontal hydraulic conductivity was not calculated for the bedrock unit because of a lack of available data. Median values of estimated hydraulic conductivity for the aquifers (AL, $328 \mathrm{ft} / \mathrm{d}$; A1, $933 \mathrm{ft} / \mathrm{d} ; \mathrm{A} 3,122 \mathrm{ft} / \mathrm{d} ; \mathrm{C}, 96 \mathrm{ft} / \mathrm{d}: \mathrm{E}, 57 \mathrm{ft} / \mathrm{d}$; and $\mathrm{G}, 33 \mathrm{ft} / \mathrm{d}$ ) are similar in magnitude to values compiled by 
Vaccaro and others (1998) for the Puget Sound lowlands and reported by Freeze and Cherry (1979) for similar materials. Median values of estimated hydraulic conductivities for the confining units $(\mathrm{A} 2,18 \mathrm{ft} / \mathrm{d} ; \mathrm{B}, 21 \mathrm{ft} / \mathrm{d} ; \mathrm{D}, 29 \mathrm{ft} / \mathrm{d}$; and $\mathrm{F}$, $131 \mathrm{ft} / \mathrm{d}$ ) are higher than is typical for most of the material in these units because data for confining units usually are from wells that are preferentially open to lenses of coarse material. As a result, the data are biased toward the more productive zones in these units and are not representative of the entire unit.

Estimates of horizontal hydraulic conductivity also were compiled from aquifer tests conducted by environmental consulting firms, and statistical summaries of these data were prepared by hydrogeologic unit (table 3). Aquifer tests data were available for public-supply wells only and are biased toward the major water-producing aquifers in the study area. Aquifer tests data were not available for the AL and A1 aquifers, or for any of the confining units.

Table 3. Summary of hydraulic conductivity values estimated from specific-capacity data and aquifers tests, by hydrogeologic unit, Chambers-Clover Creek Watershed and vicinity, Washington.

[-, no data; ft/d, feet per day $]$

\begin{tabular}{|c|c|c|c|c|}
\hline \multirow{2}{*}{$\begin{array}{l}\text { Hydrogeologic } \\
\text { unit }\end{array}$} & \multirow{2}{*}{$\begin{array}{l}\text { Number } \\
\text { of wells }\end{array}$} & \multicolumn{3}{|c|}{$\begin{array}{l}\text { Horizontal hydraulic } \\
\text { conductivity (ft/d) }\end{array}$} \\
\hline & & Minimum & Median & Maximum \\
\hline \multicolumn{5}{|c|}{ Estimated from specific-capacity data } \\
\hline $\begin{array}{l}\text { AL alluvial valley } \\
\text { aquifer }\end{array}$ & 10 & 36 & 328 & 3,779 \\
\hline A1 aquifer & 4 & 62 & 933 & 5,065 \\
\hline A2 confining unit & 5 & 1 & 18 & 144 \\
\hline A3 aquifer & 34 & 1 & 122 & 15,137 \\
\hline B confining unit & 5 & 4 & 21 & 120 \\
\hline $\mathrm{C}$ aquifer & 59 & 3 & 96 & 12,753 \\
\hline D confining unit & 3 & 18 & 29 & 32 \\
\hline E aquifer & 22 & 11 & 57 & 1,317 \\
\hline F confining unit & 1 & - & 131 & - \\
\hline $\begin{array}{l}\text { G undifferentiated } \\
\text { deposits }\end{array}$ & 17 & 7 & 33 & 936 \\
\hline \multicolumn{5}{|c|}{ Estimated from aquifer tests } \\
\hline A3 aquifer & 9 & 229 & 588 & 3,228 \\
\hline $\mathrm{C}$ aquifer & 13 & 21 & 198 & 1,337 \\
\hline E aquifer & 15 & 12 & 214 & 1,519 \\
\hline $\begin{array}{l}\text { G undifferentiated } \\
\text { deposits }\end{array}$ & 6 & 11 & 39 & 163 \\
\hline
\end{tabular}

\section{Groundwater Movement}

This section describes the movement of groundwater in the aquifer system in the study area, and includes discussions of groundwater recharge, flow direction, discharge to surface water, exchange of water between the aquifer system and streams, and temporal fluctuations in groundwater levels. These processes occur within the physical domain described by the hydrogeologic framework and are influenced by the hydrogeologic characteristics of the aquifer system in which they occur, and by other factors, including streamflow and the spatial distribution of precipitation and land cover.

\section{Recharge}

Precipitation is the dominant source of water recharging the groundwater-flow system in the study area, and it is reasonable to expect groundwater recharge to vary with precipitation. Factors such as the permeability of surficial hydrogeologic units and land-cover characteristics also affect recharge; therefore, the relation between precipitation and recharge also is likely to depend on hydrogeologic and land-cover characteristics. The distribution of recharge from precipitation in the water-budget area was estimated by applying precipitation-recharge relations based on regression equations developed for areas in Washington State by Bidlake and Payne (2001) that incorporate the effects of surficial characteristics.

Mean annual precipitation totals were calculated from daily values for the study monitoring period (September 1,2006 , to August 31,2008) and were obtained from the National Climate Data Center (NCDC) (www.ncdc.noaa.gov) for four active National Weather Service (NWS) stations in the vicinity of the study area: McMillin Reservoir (NWS station 455224), Tacoma \#1 (NWS station 458278), Olympia Airport (NWS station 456114), and Fort Lewis Golf Course (NWS station 452952). These point data were extrapolated across the study area (fig. 13) based on the spatial distribution of normal precipitation (average annual precipitation for 1971-2000) generated from the computer program Parameter-elevation Regressions on Independent Slopes Model (PRISM) (Daly and others, 1994; Oregon State University, 2009) The PRISM model estimates the distribution of normal precipitation based on a statistical method that takes into account land-surface altitude and spatial variation.

Normal precipitation at each NWS station was obtained by sampling the PRISM distribution at the four station locations, allowing the PRISM distribution to be scaled for extrapolation. The normal precipitation was compared to the annual precipitation at the NWS stations and a regression equation was developed for the four points:

$$
\mathrm{P}_{\text {actual }}=10.23 \mathrm{in} / \mathrm{yr}+0.808 \times \mathrm{P}_{\text {normal }}
$$




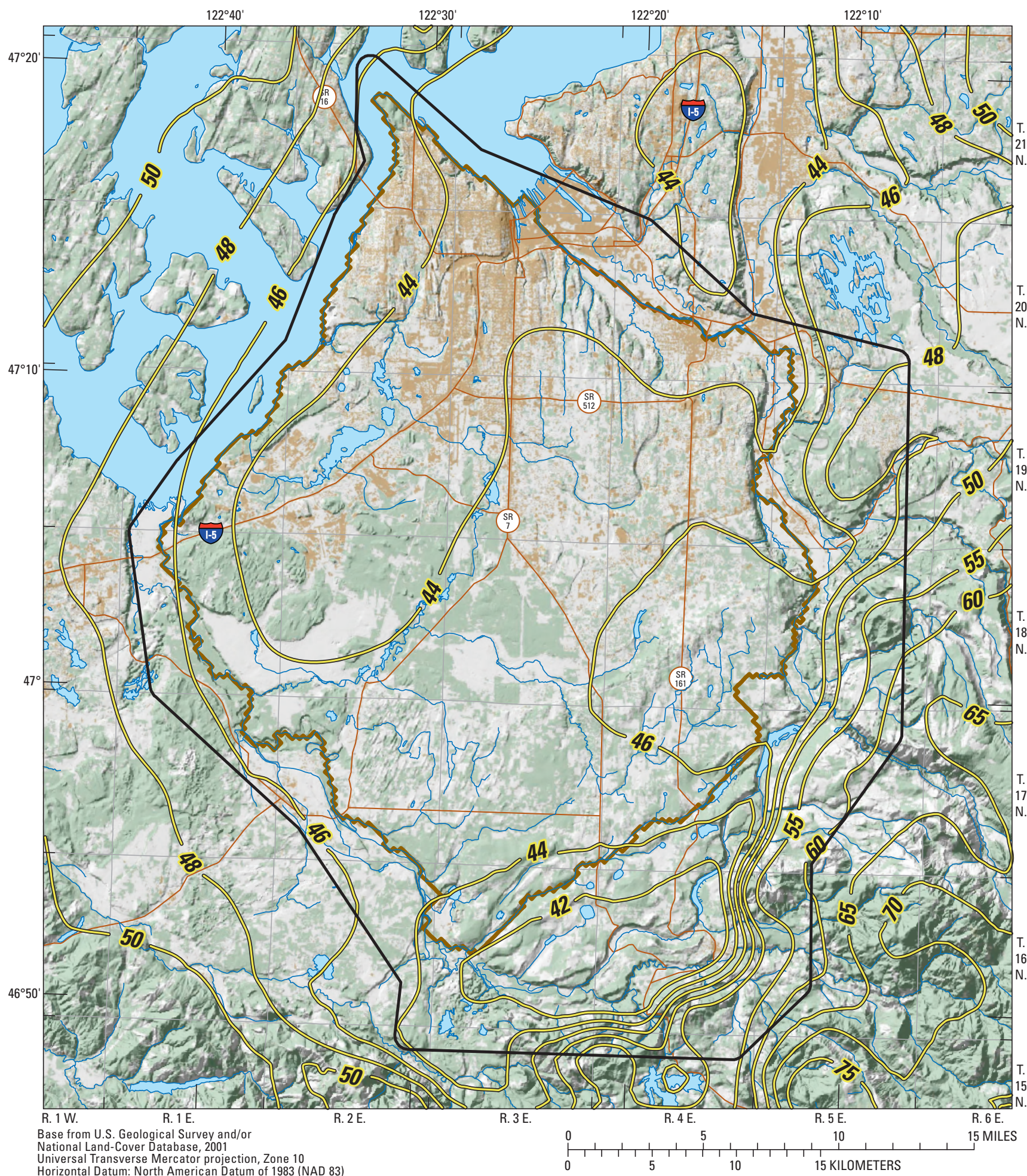

Horizontal Datum: North American Datum of 1983 (NAD 83)

EXPLANATION

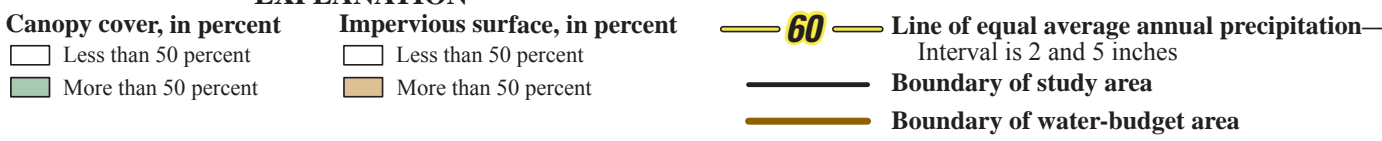

Figure 13. Average annual precipitation, canopy cover, and impervious surface across the Chambers-Clover Creek Watershed and vicinity, Washington, September 2006-August 2008. 
This relation has a correlation coefficient of 0.96 and was used to estimate the distribution of mean annual precipitation for the study monitoring period (September 1, 2006, to August 31, 2008) throughout the study area (fig. 13), based on the PRISM distribution of normal precipitation. The study area received an average (September 1, 2006, to August 31, 2008) of about 1,025,000 acre-ft or about $45 \mathrm{in} / \mathrm{yr}$ of precipitation a year.

The effects of surficial hydrogeology on recharge from precipitation (fig. 14) were estimated using regression equations developed by Bidlake and Payne (2001) for soils in western Washington. Recharge estimates for aquifer units (outwash and alluvium) exposed at land surface in the study area were calculated using regression equation developed for soils formed on glacial outwash and alluvial sediments. Recharge estimates for confining units (till and lacustrine) were calculated using regression equation developed for soils formed on glacial till and fine-grained sediments.

The effect of evaporative loss on recharge from the interception of precipitation by tree canopy was estimated for aquifers using equations from Bidlake and Payne (2001). Tree canopy distribution data were obtained from the National Land Cover Database (NLCD) (2001). Interception loss was applied only to areas with more than 50 percent tree canopy (fig. 13).

Urban centers in the study area manage stormwater by discharging runoff either to dry wells that promote the infiltration of this water into the groundwater-flow system or to streams in areas where soils are incapable of receiving the extra water. Therefore, recharge through confining units (such as A2 and B) at the ground surface was reduced by one-half according to the method of Bidlake and Payne (2001) where the percentage of impervious surface was greater than 50 percent (fig. 13) as derived from the National Land Cover Database (2001). No direct recharge from precipitation was assumed for areas covered by lakes.

GIS techniques were used to combine the data coverages described in the previous paragraphs and calculate the distribution of groundwater recharge from precipitation in the water-budget area (fig. 15). Recharge rates ranged from about $6 \mathrm{in} / \mathrm{yr}$ in urban areas (greater than 50 percent impervious surface) underlain by confining units to about $30 \mathrm{in} / \mathrm{yr}$ in areas underlain by permeable aquifer deposits with less than 50 percent tree canopy in the eastern-central part of the area where precipitation locally exceeds $48 \mathrm{in} / \mathrm{yr}$. Summing the recharge areas shown in figure 15 indicates that the groundwater-flow system within the water-budget area receives about 455,000 acre-ft or about $20 \mathrm{in}$. of recharge from precipitation during an average year (September 1, 2006, to August 31, 2008).

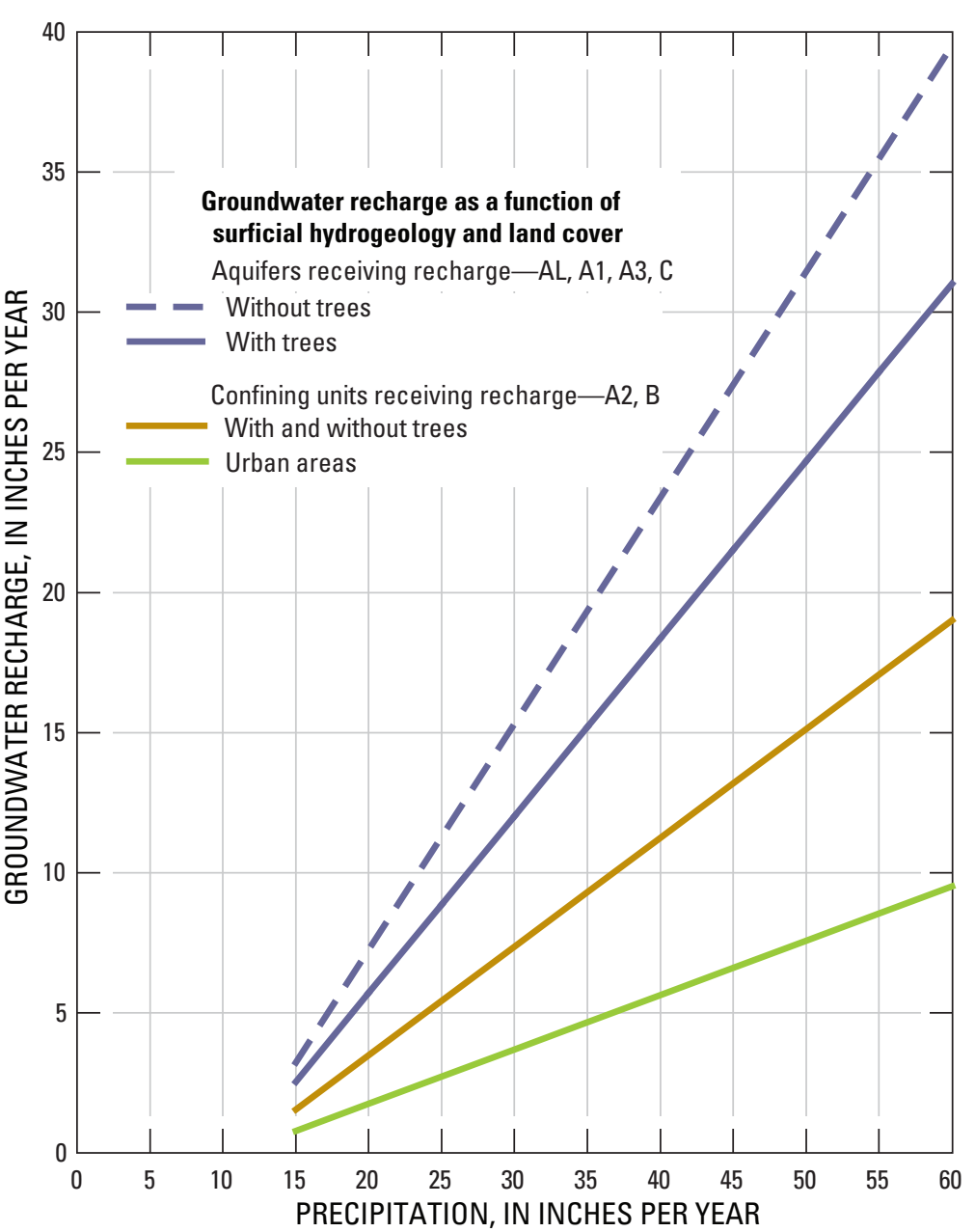

Figure 14. Precipitation-recharge relations used in this study, Chambers-Clover Creek Watershed and vicinity, Washington.
Both the spatial distribution and the annual amounts of recharge estimated for this study are similar to estimates made by Vaccaro and others (1998) in an assessment of the Puget Sound Regional Aquifer System. However, the recharge estimates for confining units (till and lacustrine deposits) used in this study (generally 5 to $15 \mathrm{in} / \mathrm{yr}$ depending on land cover) are substantially greater than the $2.6 \mathrm{in} / \mathrm{yr}$ average value estimated by Mastin (1996) and Bauer and Mastin (1997) for till-mantled areas in Clover Creek basin. The $2.6 \mathrm{in} / \mathrm{yr}$ estimate primarily was derived from site-scale measurements, and the successful incorporation of the estimate into the Clover Creek basin model (Mastin, 1996) required including poorly constrained assumptions about groundwater flow out of the modeling domain. Recharge estimates used in other investigations for till-mantled areas in the Puget Sound region (Turney and others, 1995; Drost and others, 1999; van Heeswijk and Smith, 2002) are similar to the estimates used in this study. 


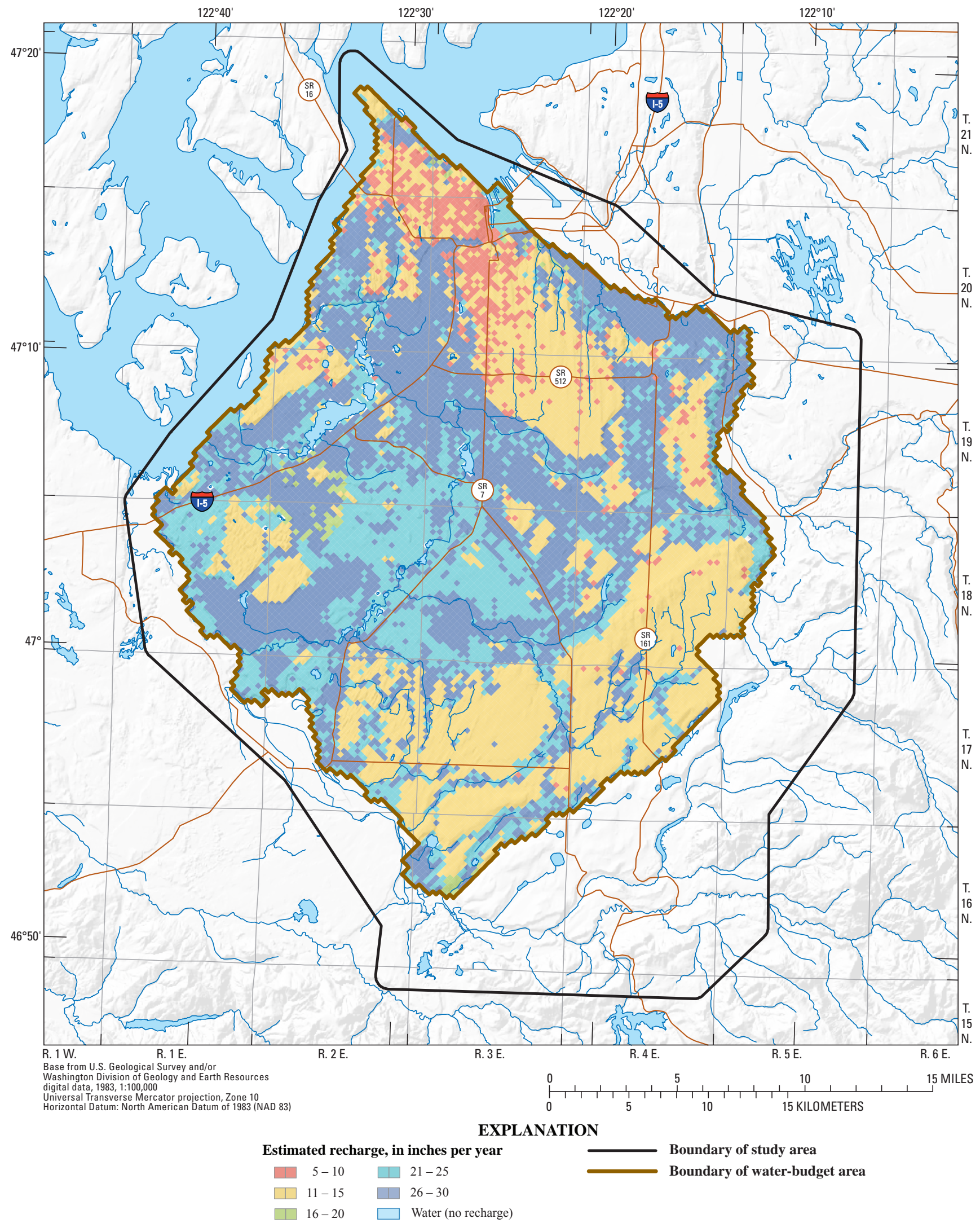

Figure 15. Distribution of average annual groundwater recharge from precipitation in Chambers-Clover Creek Watershed and vicinity, Washington, September 2006-August 2008. 
In addition to groundwater recharge from precipitation, groundwater recharge from streams also occurs in the study area along losing stream reaches. The total amount of groundwater recharge from streams is not quantified here, but is reflected in the computation of the total net groundwater discharge to streams presented in the water budget.

\section{Groundwater-Flow Directions}

The generalized direction of horizontal groundwater movement was inferred from maps of water-level altitude contours. Groundwater generally moves from areas of recharge to areas of discharge in the direction of decreasing water-level altitudes and is perpendicular to the water-level altitude contours. Groundwater levels measured during operation of the monthly monitoring network (March 2007 - September 2008) were used to evaluate groundwater-flow directions in aquifers within the study area (figs. 16 through 21). The mean water-level value for the period of record was used to represent the water-level altitude at monthly monitoring wells for this analysis. Synoptic measurements of groundwater levels made during the field inventory (September-December 2006) were used only in areas where monthly water-level data were not available, and, in places, field inventory values do not correlate well with water-level altitude contours based on monthly data. Water-level contours for most aquifer units are based on limited water-level data and are subject to some uncertainty. For the same reason, the illustrated groundwaterflow directions for the uppermost units in particular are generalized and do not reflect local flow characteristics, such as groundwater discharge to or recharge from streams. Water-level contours were not drawn for large parts of aquifer units $\mathrm{E}$ and $\mathrm{G}$ because of a lack of data. A numerical flow model of the groundwater-flow system in the study area, currently under development, should provide additional insight into groundwater-flow directions.

In the northeastern part of the study area, groundwater flow in the AL alluvial valley aquifer beneath the Puyallup River valley is towards the northwest in the down-valley direction of the river, towards Puget Sound (fig. 16). A northwest down-valley groundwater flow direction also is likely in the AL alluvial valley aquifer beneath the Nisqually River valley in the southern part of the area (inset, fig. 16) although no data were collected from the aquifer in this area.

Groundwater flow in the A1 and A3 aquifers generally is towards the northwest (figs. 17 and $\underline{18}$, respectively). North and northeastward groundwater flows in the A1 aquifer are inferred from widely spaced water-level data in the northeastern part of the area (fig. 17). Water-level data in this area suggest the presence of a groundwater divide that separates flow towards the Puyallup River valley and groundwater movement towards Puget Sound. A similar divergence of groundwater flow (northeast and northwest flow directions) in the A3 aquifer is indicated by water-level data in the central part of the study area (fig. 18) and suggests that northeast flow occurs over a larger part of the A3 aquifer than the A1 aquifer. Large areas of low permeability glacial till (B confining unit) separate the A1 aquifer to the south and Puyallup River valley to the north, and likely are barriers to groundwater flow.

Groundwater flow in the $\mathrm{C}$ aquifer diverges to the northwest and northeast along a complex, groundwater divide (fig. 19). Water-level data in the northwestern part of the $\mathrm{C}$ aquifer in the study area indicate localized groundwater flow towards the west in the direction of the Puget Sound. Northwest to northeast groundwater flow in the E aquifer is inferred from widely spaced water-level data in the northern part of the study area (fig. 20). Water-level data from three wells in the $\mathrm{G}$ undifferentiated deposits suggest that northwestward groundwater flow is likely in the northwestern part of the study area (fig. 21).

The potential for vertical flow between aquifers is difficult to determine because extents and thicknesses of hydrogeologic units vary considerably throughout the study area, the presence of confining layers within and between aquifers is highly variable, and the data available for comparing water levels between adjacent units are widely spaced. Small water-level differences between the A1 and A3 aquifers in the north-central part of the study area, where sufficient contoured data were available to make a comparison, suggest little in the way of vertical flow potential between the aquifers (figs. 17 and 18). Downward vertical flow from the A1 to A3 aquifers may occur in an area of widely spaced water levels in the northeastern part of the area, but the discontinuous nature of the A1 aquifer makes direct comparison difficult. Water-level differences between the A3 and $\mathrm{C}$ aquifers show the potential for downward vertical flow in western (vicinity of American, Gravelly, and Steilacoom Lakes) and eastern (along the bluffs of the Puyallup River valley) parts of the study area (figs. 18 and $\underline{19}$ ).

The potential for upward groundwater flow is indicated by the presence of flowing wells at several locations in the aquifer units. Confining clays within the AL alluvial valley aquifer likely produce flowing conditions observed at four wells in the Puyallup River valley (fig. 16), and an upward vertical gradient in this area is supported by water levels in nearby non-flowing wells in the AL alluvial valley aquifer. The potential for upward flow in the $\mathrm{C}$ aquifer is indicated by the presence of a flowing well in the Puyallup River valley in the northern part of the study area (fig. 19), and an upward vertical gradient in this area is supported by water levels in the overlying AL alluvial valley aquifer. 


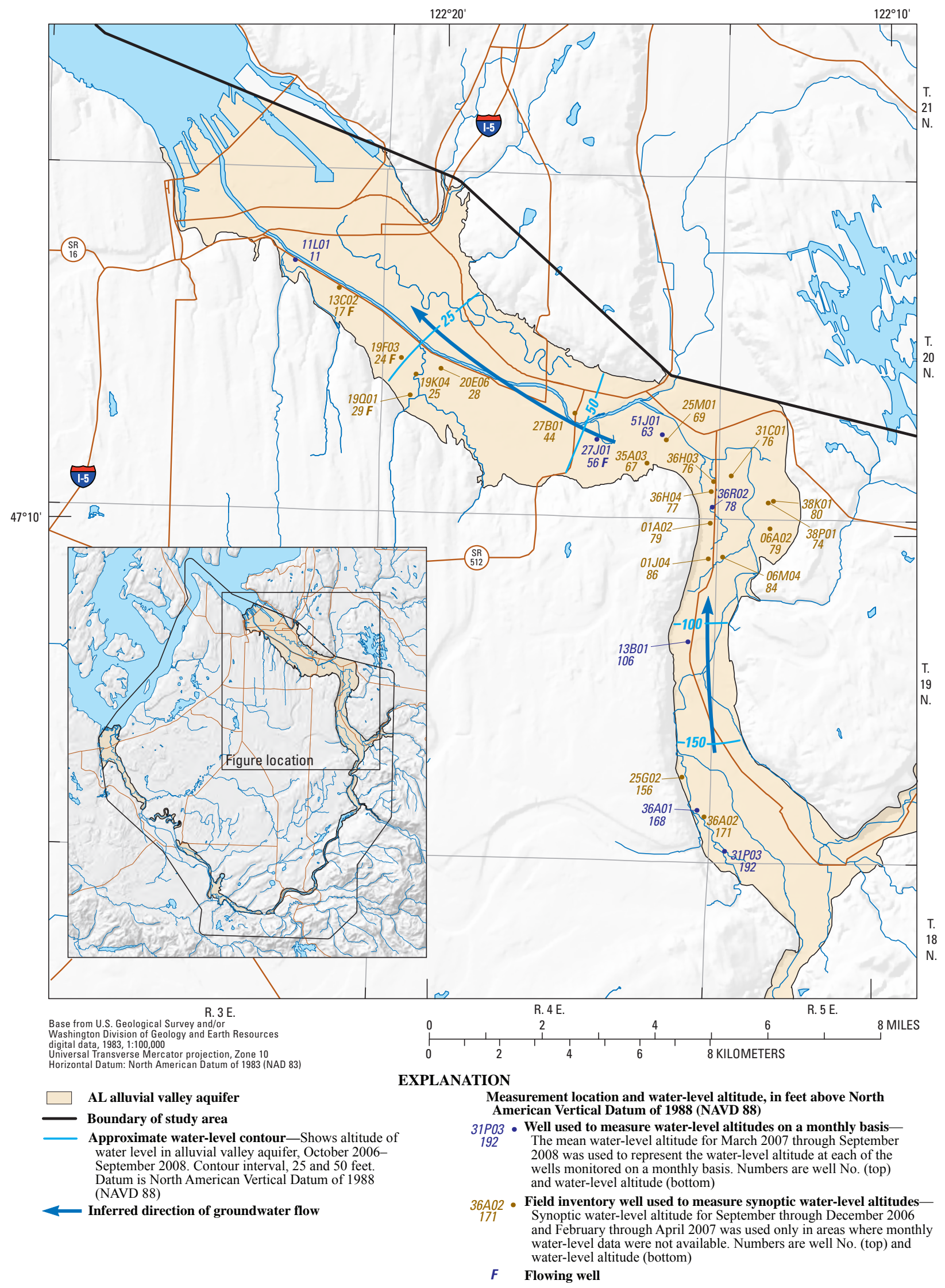

Figure 16. Water-level altitudes and direction of groundwater flow in AL alluvial valley aquifer, Chambers-Clover Creek Watershed and vicinity, Washington, September 2006-September 2008. 


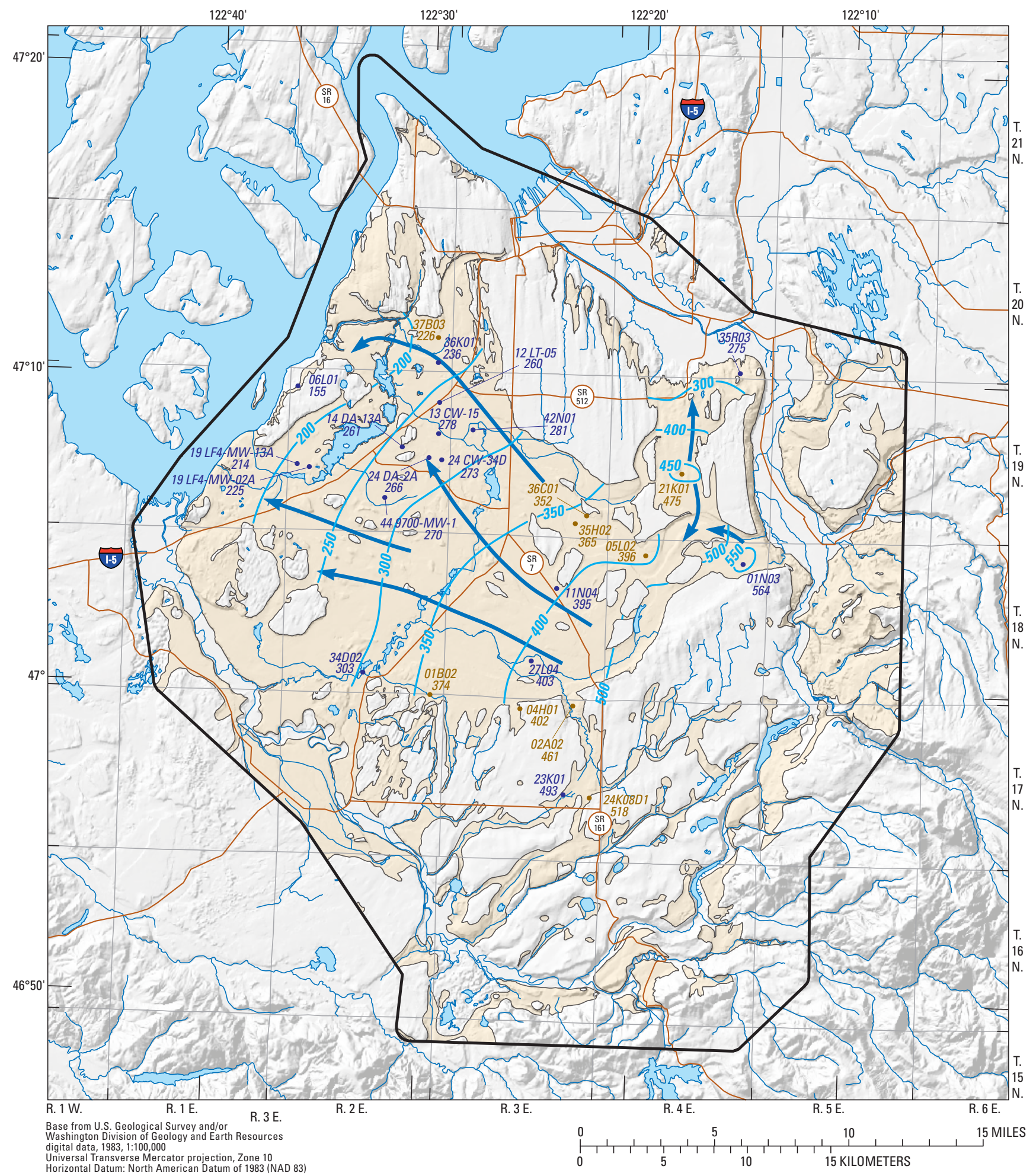

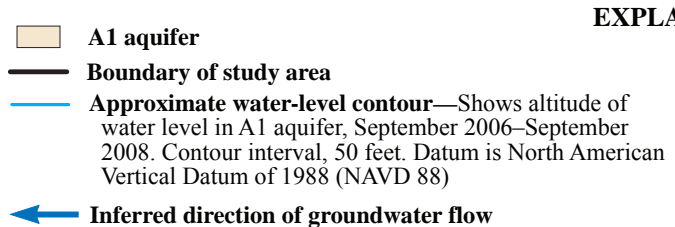

Figure 17. Water-level altitudes and direction of groundwater flow in A1 aquifer, Chambers-Clover Creek Watershed and vicinity, Washington, September 2006-September 2008.

\footnotetext{
M easurement location and water-level altitude, in feet above North A merican Vertical Datum of 1988 (NAVD 88)

$04 N 01$ - Well used to measure water-level altitudes on a monthly basis The mean water-level altitude for March 2007 through September 2008 was used to represent the water-level altitude at each of the wells monitored on a monthly basis. Numbers are well No. (top) and water-level altitude (bottom)

05002 - Field inventory well used to measure synoptic water-level altitudes Synoptic water-level altitude for September through December 2006 Synoptic water-level altitude for September through December 2006
and February through April 2007 was used only in areas where monthly water-level data were not available. Numbers are well No. (top) and water-level altitude (bottom)
} 


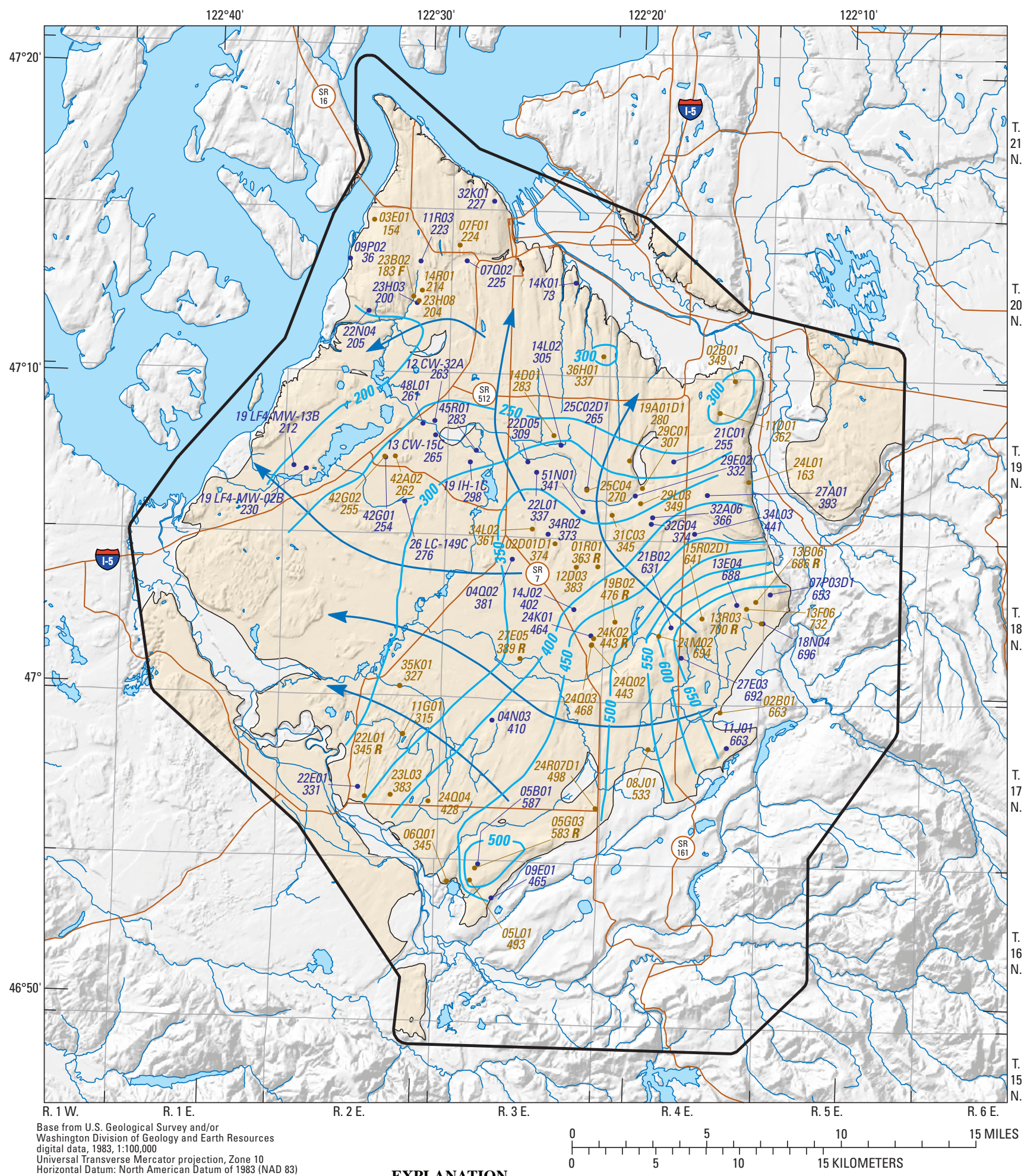

Universal Transverse Mercator projection, Zone 10

Horizontal Datum: North American Datum of 1983 (NAD 83) EXPLANATION

Boundary of study area

- Approximate water-level contour- Shows altitude of water level in A3 aquifer, September 2006-September 2008. Contour interval, 50 feet. Datum is North American Vertical Datum of 1988 (NAVD 88)

$\leftarrow$ Inferred direction of groundwater flow

Figure 18. Water-level altitudes and direction of groundwater flow in A3 aquifer, Chambers-Clover Creek Watershed and vicinity, Washington, September 2006-September 2008.

Measurement location and water-level altitude, in feet above North A merican Vertical Datum of 1988 (NAVD 88)

$04 \mathrm{NO}$ - Well used to measure water-level altitudes on a monthly basis

410 The mean water-level altitude for March 2007 through September 2008 was used to represent the water-level altitude at each of the wells monitored on a monthly basis. Numbers are well No. (top) and water-level altitude (bottom)

24004 - Field inventory well used to measure synoptic water-level altitudes Synoptic water-level altitude for September through December 2006 and February through April 2007 was used only in areas where monthly water-level data were not available. Numbers are well No. (top) and water-level altitude (bottom)

F Flowing well $\quad \boldsymbol{R}$ Recovering well 


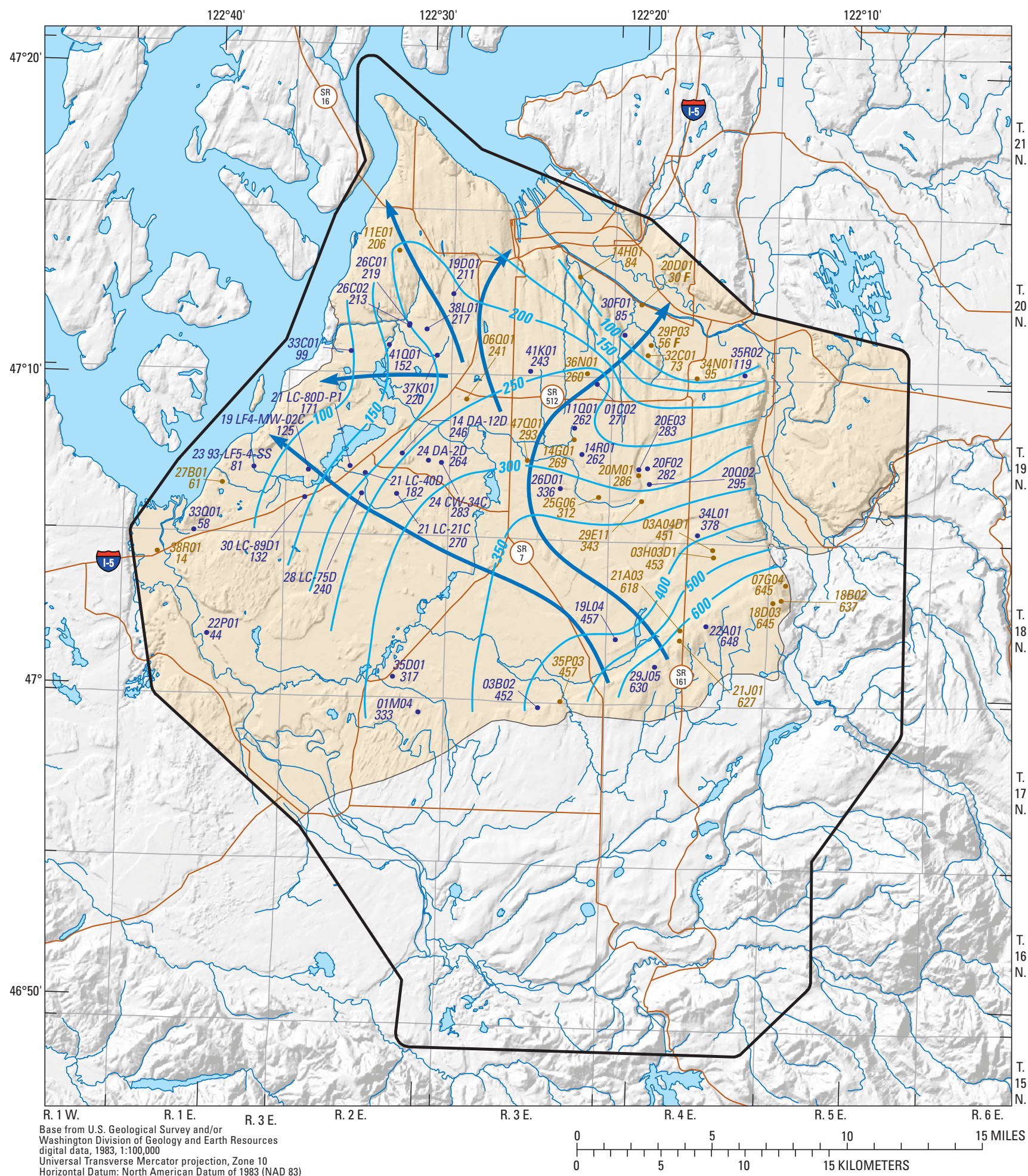

Universal Transverse Mercator projection, Zone 10
Horizontal Datum: North American Datum of 1983 (NAD 83

\section{C aquifer}

EXPLANATION

- Boundary of study area

A pproximate water-level contour- Shows altitude of water level in C aquifer, September 2006-September 2008 Contour interval, 50 feet. Datum is North American Vertical Datum of 1988 (NAVD 88)

Inferred direction of groundwater flow

Figure 19. Water-level altitudes and direction of groundwater flow in C aquifer, Chambers-Clover Creek Watershed and vicinity, Washington, September 2006-September 2008.
M easurement location and water-level altitude, in feet above North American Vertical Datum of 1988 (NAVD 88)

$19 L 04$ - Well used to measure water-level altitudes on a monthly basis

1957 The mean water-level altitude for March 2007 through September 2008 was used to represent the water-level altitude at each of the wells monitored on a monthly basis. Numbers are well No. (top) and water-level altitude (bottom)

$35 P 03$ - Field inventory well used to measure synoptic water-level altitudes Synoptic water-level altitude for September through December 2006 and February through April 2007 was used only in areas where monthly water-level data were not available. Numbers are well No. (top) and water-level altitude (bottom)

$F \quad$ Flowing well $\quad R$

Recovering well 


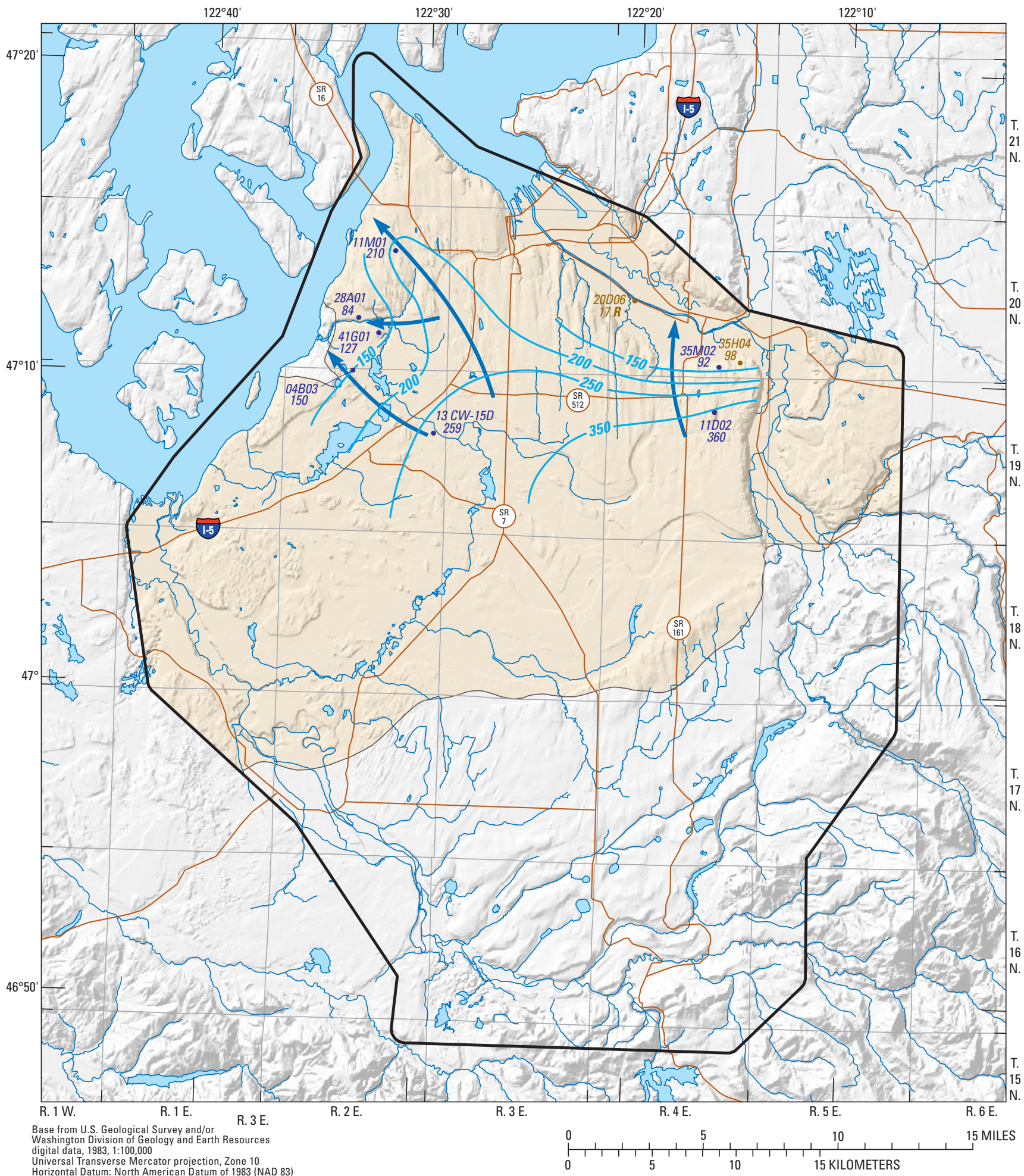

American Datum of 1983 (NAD 83)

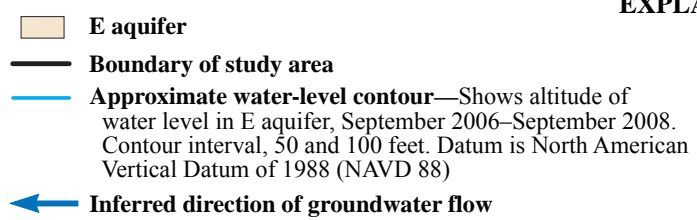

Figure 20. Water-level altitudes and direction of groundwater flow in E aquifer, Chambers-Clover Creek Watershed and vicinity, Washington, September 2006-September 2008.

\section{M easurement location and water-level altitude, in feet above North American Vertical Datum of 1988 (NAVD 88) \\ 11D02 - Well used to measure water-level altitudes on a monthly basis The mean water-level altitude for March 2007 through September 2008 was used to represent the water-level altitude at each of the wells monitored on a monthly basis. Numbers are well No. (top) and water-level altitude (bottom) \\ $35 \mathrm{HO} 4$ - Field inventory well used to measure synoptic water-level altitudes} Synoptic water-level altitude for September through December 2006 and February through April 2007 was used only in areas where monthly water-level data were not available. Numbers are well No. (top) and water-level altitude (bottom)

F Flowing well $\quad R \quad$ Recovering well 


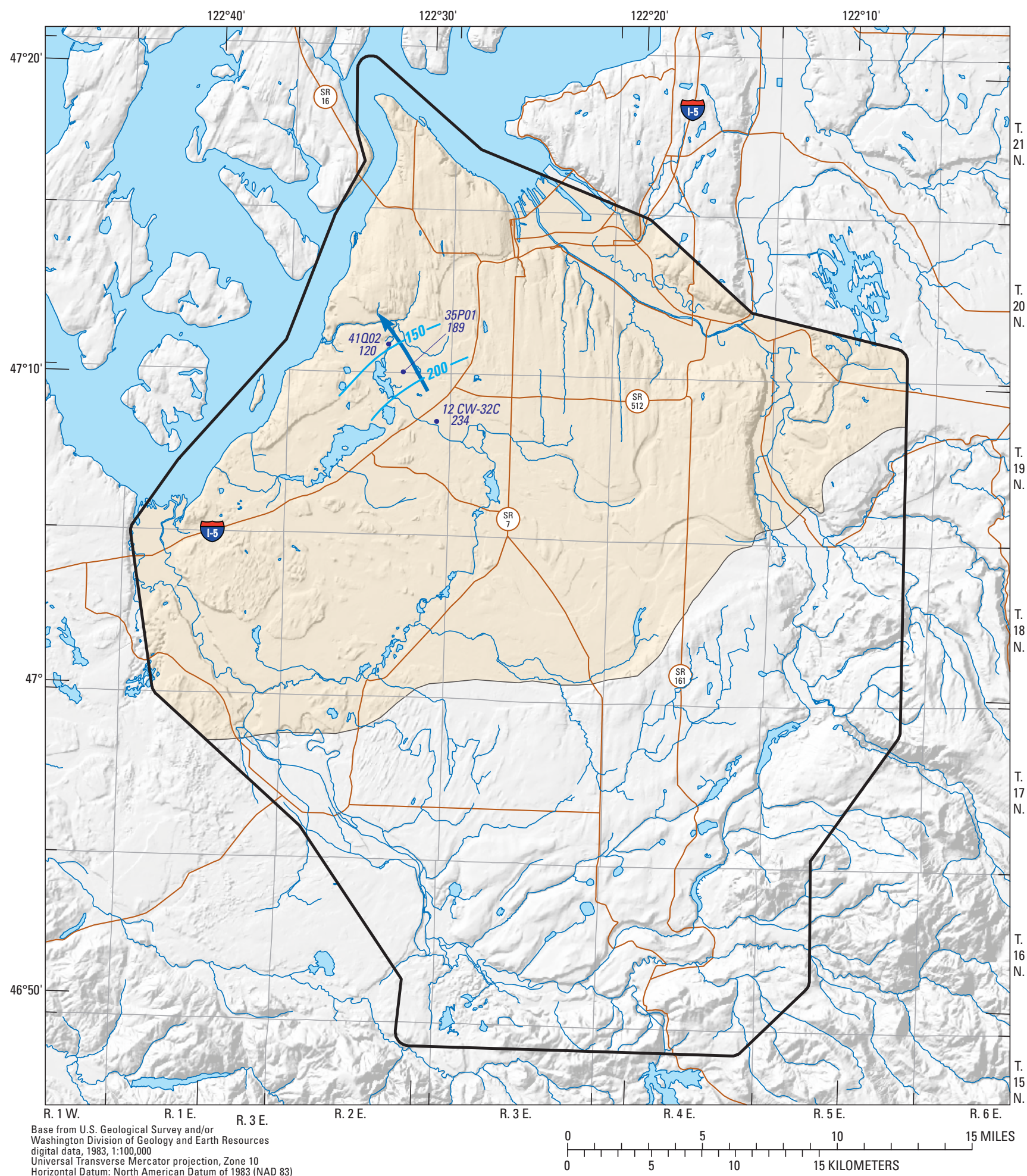

Universal Transverse Mercator projection, Zone 10
Horizontal Datum: North American Datum of 1983 (NAD 83)

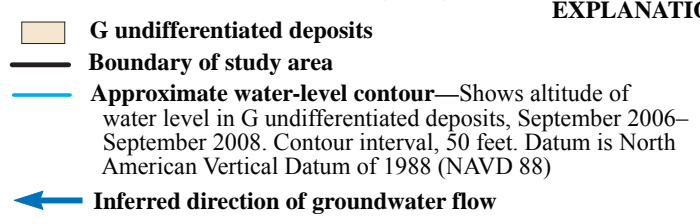

Measurement location and water-level altitude, in feet above North American Vertical Datum of 1988 (NAVD 88)

41002 - Well used to measure water-level altitudes on a monthly basis

120 The mean water-level altitude for March 2007 through September 2008 was used to represent the water-level altitude at each of the wells monitored on a monthly basis. Numbers are well No. (top) and water-level altitude (bottom)

Figure 21. Water-level altitudes and direction of groundwater flow in $\mathrm{G}$ undifferentiated deposits, Chambers-Clover Creek Watershed and vicinity, Washington, September 2006-September 2008. 


\section{Discharge}

Groundwater in the study area discharges as seepage to streams, lakes, springs, marshes, and coastal bluffs; as evaporation and transpiration of shallow groundwater; as submarine seepage to Puget Sound; and as withdrawals from wells. Groundwater discharge sustains the late-summer and early-fall flow (baseflow) of streams in the study area. Estimates of groundwater discharge to streams in the study area were based on synoptic streamflow measurements conducted in September 2007 and July 2008 at seven locations near the outlets of the major streams draining the study area (table 4 and pl. 1), and estimates of evaporative loss from groundwater fed lakes within measured reaches (National Oceanic and Atmospheric Administration, 1982). Estimates of daily evaporative loss from lakes were used to account for losses in baseflow during synoptic streamflow measurements (September 2007 and July 2008). These estimates were based on maps of annual evaporation for shallow lakes in the vicinity of the study area (National Oceanic and Atmospheric Administration, 1982). Maps were developed using data from Class A pan evaporation stations and other spatially distributed meteorological data for 1956-1970. The accuracy of the maps is a function of the number of nearby data stations and their proximity to the area of interest; the closest stations are located in the southern Puget Sound area. Estimates of annual evaporation assume long-term thermal stability of lake water. Daily values of evaporation were estimated using the average monthly percentage of annual evaporation derived from Class A pan evaporation data (National Oceanic and Atmospheric Administration, 1982) for 1956-70.

Table 4. Synoptic streamflow measurements and estimates of evaporative loss from lakes used to determine groundwater discharge in the Chambers-Clover Creek Watershed and vicinity, Washington, September 2007 and July 2008.

[Discharge rating: Accuracy rating of U.S. Geological Survey measurements: G, good; F, fair; P, poor; -, no rating; estimated values are rated poor. Abbreviations: $\mathrm{ft}^{3} / \mathrm{s}$, cubic feet per second]

\begin{tabular}{|c|c|c|c|c|}
\hline Measurement site name & Site No. & $\begin{array}{l}\text { Date discharge } \\
\text { measured }\end{array}$ & $\begin{array}{c}\text { Discharge } \\
\left(\mathrm{ft}^{3} / \mathrm{s}\right)\end{array}$ & $\begin{array}{l}\text { Discharge } \\
\text { rating }\end{array}$ \\
\hline \multirow[t]{2}{*}{ Swan Creek at Pioneer Way East } & 12102212 & $09-11-07$ & 2.75 & $\mathrm{~F}$ \\
\hline & & $07-10-08$ & 1.81 & $\mathrm{~F}$ \\
\hline \multirow[t]{2}{*}{ Clear Creek at 31 st Ave East } & 12102175 & 09-11-07 & 14.7 & $\mathrm{~F}$ \\
\hline & & $07-10-08$ & 16.3 & $\mathrm{~F}$ \\
\hline \multirow[t]{2}{*}{ Clarks Creek at Stewart Ave at railroad bridge } & 12102060 & 09-10-07 & 50.9 & $\mathrm{~F}$ \\
\hline & & 07-09-08 & 50.5 & $\mathrm{~F}$ \\
\hline \multirow[t]{2}{*}{ Chambers Creek upstream of Chambers Bay } & 12091590 & $09-10-07$ & 49.0 & G \\
\hline & & 07-09-08 & 51.3 & G \\
\hline \multirow[t]{2}{*}{ Murray Creek at 41st Division Way (Camp Murray) } & 12090290 & 09-10-07 & 1.21 & $\mathrm{~F}$ \\
\hline & & $07-10-08$ & 1.85 & $\mathrm{~F}$ \\
\hline \multirow[t]{2}{*}{ Sequalitchew Creek at Center Drive } & 12090315 & 08-09-07 & 0.00 & - \\
\hline & & $07-10-08$ & ${ }^{1} 0.00$ & $\mathrm{P}$ \\
\hline \multirow[t]{2}{*}{ Muck Creek at Roy (bridge at Warren Street) } & 12090200 & 09-10-07 & 0.00 & - \\
\hline & & 07-09-08 & 1.70 & G \\
\hline \multirow[t]{2}{*}{ Evaporative loss from Lake Steilacoom } & & September 2007 & ${ }^{2} 1.1$ & \\
\hline & & July 2008 & 22.2 & \\
\hline \multirow[t]{2}{*}{ Evaporative loss from Spanaway Lake } & & September 2007 & ${ }^{2} 0.9$ & \\
\hline & & July 2008 & ${ }^{2} 1.7$ & \\
\hline \multirow[t]{2}{*}{ Total net measured streamflow } & & September 2007 & 120.6 & \\
\hline & & July 2008 & 127.4 & \\
\hline
\end{tabular}

\footnotetext{
${ }^{1}$ Estimated by U.S. Geological Survey based on streamflow observation from 2007.

${ }^{2}$ Calculated daily evaporative loss derived from National Oceanic and Atmospheric Administration (1982) annual values.
} 
Groundwater discharge estimates represent flow from contributing areas upstream of the synoptic streamflow measurement sites $\left(235.4 \mathrm{mi}^{2}\right)$ and do not include contributing areas in downstream portions of the subbasins $\left(28.1 \mathrm{mi}^{2}\right)$. A total net of approximately $120.6 \mathrm{ft}^{3} / \mathrm{s}$ $(87,310 \mathrm{acre}-\mathrm{ft} / \mathrm{yr})$ of groundwater discharge to streams was measured during September 2007, and approximately $127.4 \mathrm{ft}^{3} / \mathrm{s}(92,230$ acre- $\mathrm{ft} / \mathrm{yr})$ of groundwater discharged to streams measured during July 2008 (table 4). These discharge estimates should be considered near-minimum values because streamflow measurements were made during the dry summer period when groundwater levels typically are at annual lows. During wetter periods, water levels are usually higher, thus, larger quantities of groundwater likely flow to streams. Many small streams were not measured, but they may collectively receive a large quantity of groundwater discharge at various times throughout the year.

The time-averaged (mean of the September 2007 and July 2008 discharge measurements), area-weighted net groundwater discharge (excluding groundwater discharge to the Puyallup and Nisqually Rivers, which was not measured) was estimated to be $126.8 \mathrm{ft}^{3} / \mathrm{s}(91,800 \mathrm{acre}-\mathrm{ft} / \mathrm{yr})$. This value includes area-weighted estimates of groundwater discharge for portions of stream reaches that were downstream of synoptic measurement sites. Area-weighted values (measured discharge divided by the contributing area upstream of the measurement site) were derived for each of the stream basins to better represent spatial variation in groundwater-discharge characteristics. The use of a time-averaged groundwater-discharge estimate, derived from measurements made during the dry summer period, to compute the area-weighted groundwater discharge in the study area may not accurately represent the total annual variation in discharge and likely introduces some error into this calculation. An estimate of groundwater discharge to the Puyallup and Nisqually Rivers, along with submarine seepage to Puget Sound, was computed as a residual component (other natural discharge) in the water budget presented in this report.

The long-term time-averaged (mean discharge for the period of record for all streamflow- gaging stations), area-weighted streamflow for the entire water-budget area was estimated to be $217.5 \mathrm{ft}^{3} / \mathrm{s}$ (157,500 acre-ft/yr). The long-term, time-averaged streamflow estimate incorporates surface runoff from precipitation, as well as contributions to streamflow from groundwater discharge.

Groundwater withdrawals from wells in the waterbudget area in 2007 were an estimated 58,500 acre-ft. This quantity represents gross withdrawals and does not reflect the quantity of water returned to the groundwater system through septic tanks or through irrigation return flows to shallow aquifers. Groundwater withdrawals for Class A and B public water-supply systems $(52,200$ acre-ft) were estimated using typical per capita water use rates of 138 and 109 gallons per day, respectively. These typical use rates were based on reported withdrawals from several public water suppliers in the area, and groundwater withdrawal and use data collected by the USGS (Ron Lane, written communication, 2009). Public water-supply system service populations were obtained from the Washington State Department of Health public water system data base (WDOH, 2007). Self-supplied domestic groundwater withdrawals (3,000 acre-ft) were estimated using a typical per capita water use rate of 104 gallons per day (Ron Lane, written communication, 2009), and an estimate of the self-supplied population in the area (U.S. Department of Commerce, 2007). Groundwater withdrawals for the irrigation of golf courses, cemeteries, and agricultural crops (3,300 acre-ft) were estimated using an application rate of 1.48 acre- $\mathrm{ft} / \mathrm{yr}$ for golf courses and cemeteries, and an application rate of 1.21 acre-ft/yr for crops (Ron Lane, written communication, 2009).

Groundwater discharge occurs at numerous springs in the study area, and spring locations and discharge have been previously reported in several studies (Blair, 1929; Sceva and others, 1955; Walters and Kimmel, 1968; Jones and others, 1999). The total previously reported discharge of springs in the area is about $110 \mathrm{ft}^{3} / \mathrm{s}(80,000$ acre-ft/yr). Spring discharge values compiled from previous studies span a 70 -year time period. Spring discharge has varied considerable during this period at many locations, and discharge has ceased at other locations. The most recently reported discharge was used in this compilation for springs with multiple discharge measurements, and springs that no longer flow were excluded. There are, in addition, many unmeasured springs and the total spring discharge in the area is unknown.

Groundwater discharge as evaporation and transpiration of shallow groundwater, and as submarine seepage to Puget Sound was not directly measured during this study. However, estimates for these components were computed as residuals during development of the water budget and are described in the section, "Water Budget."

\section{Groundwater and Surface-Water Interactions}

The exchange of water between the groundwater-flow system and streams in the study area was characterized using (1) synoptic streamflow measurements made in September 2007 and July 2008 at 51 stream locations (table 5 and pl. 1); (2) a streamflow measurement for Ponce de Leon Creek made in September 2006 by Pierce Conservation District (written commun., 2008); and (3) estimates of evaporative loss from lakes in measured reaches (National Oceanic and Atmospheric Administration, 1982). This information was used to identify stream reaches that gain flow and reaches that lose flow to the groundwater-flow system. Streamflow measurements were made during the low-flow season, usually July-September (fig. 22), to capture baseflow conditions. Streamflow in the study area remained fairly constant during the September 2007 and July 2008 measurement periods (figs. 23 and 24). 
Table 5. Synoptic streamflow measurements and estimates of gains and losses in the Chambers-Clover Creek Watershed and vicinity, Washington, September 2007 and July 2008.

[Site No.: Location of sites shown on plate 1. Discharge rating: Accuracy rating of U.S. Geological Survey measurements: G, good; F, fair; P, poor; -, no rating; estimated values are rated poor. G ain or L oss: Uncertainties due to measurement error were too large at some locations to make defensible conclusions regarding the characterization of gaining or losing stream reaches and those values are italicized. Abbreviations: $\mathrm{ft}^{3} / \mathrm{s}$, cubic feet per second]

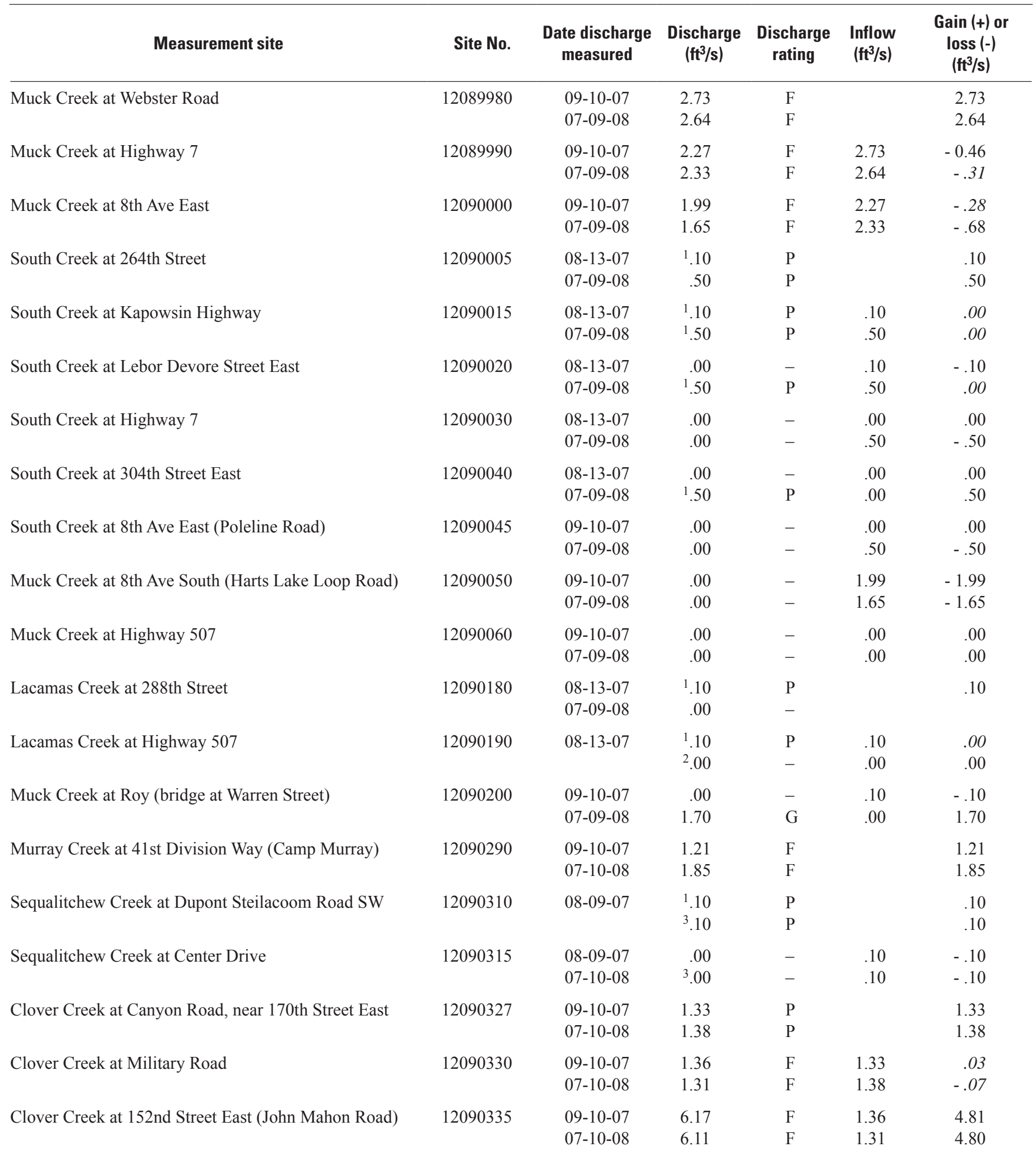


Table 5. Synoptic streamflow measurements and estimates of gains and losses in the Chambers-Clover Creek Watershed and vicinity, September 2007 and July 2008. - Continued

[Site No.: Location of sites shown on plate 1. Discharge rating: Accuracy rating of U.S. Geological Survey measurements: G, good; F, fair; P, poor; -, no rating; estimated values are rated poor. G ain or L oss: Uncertainties due to measurement error were too large at some locations to make defensible conclusions regarding the characterization of gaining or losing stream reaches and those values are italicized. Abbreviations: $\mathrm{ft}^{3} / \mathrm{s}$, cubic feet per second]

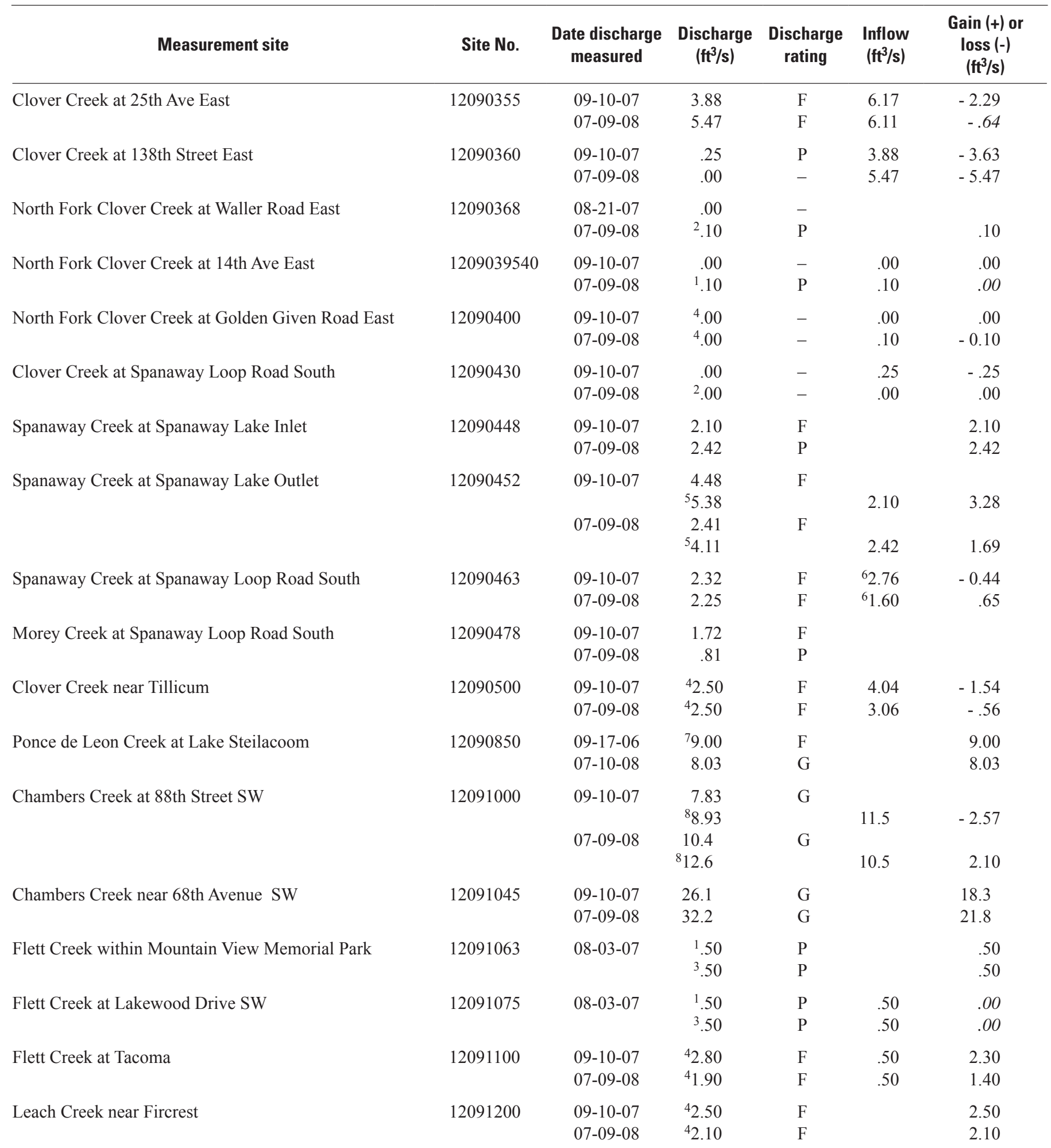


Table 5. Synoptic streamflow measurements and estimates of gains and losses in the Chambers-Clover Creek Watershed and vicinity, September 2007 and July 2008.-Continued

[Site No.: Location of sites shown on plate 1. Discharge rating: Accuracy rating of U.S. Geological Survey measurements: G, good; F, fair; P, poor; -, no rating; estimated values are rated poor. G ain or L oss: Uncertainties due to measurement error were too large at some locations to make defensible conclusions regarding the characterization of gaining or losing stream reaches and those values are italicized. Abbreviations: $\mathrm{ft}^{3} / \mathrm{s}$, cubic feet per second]

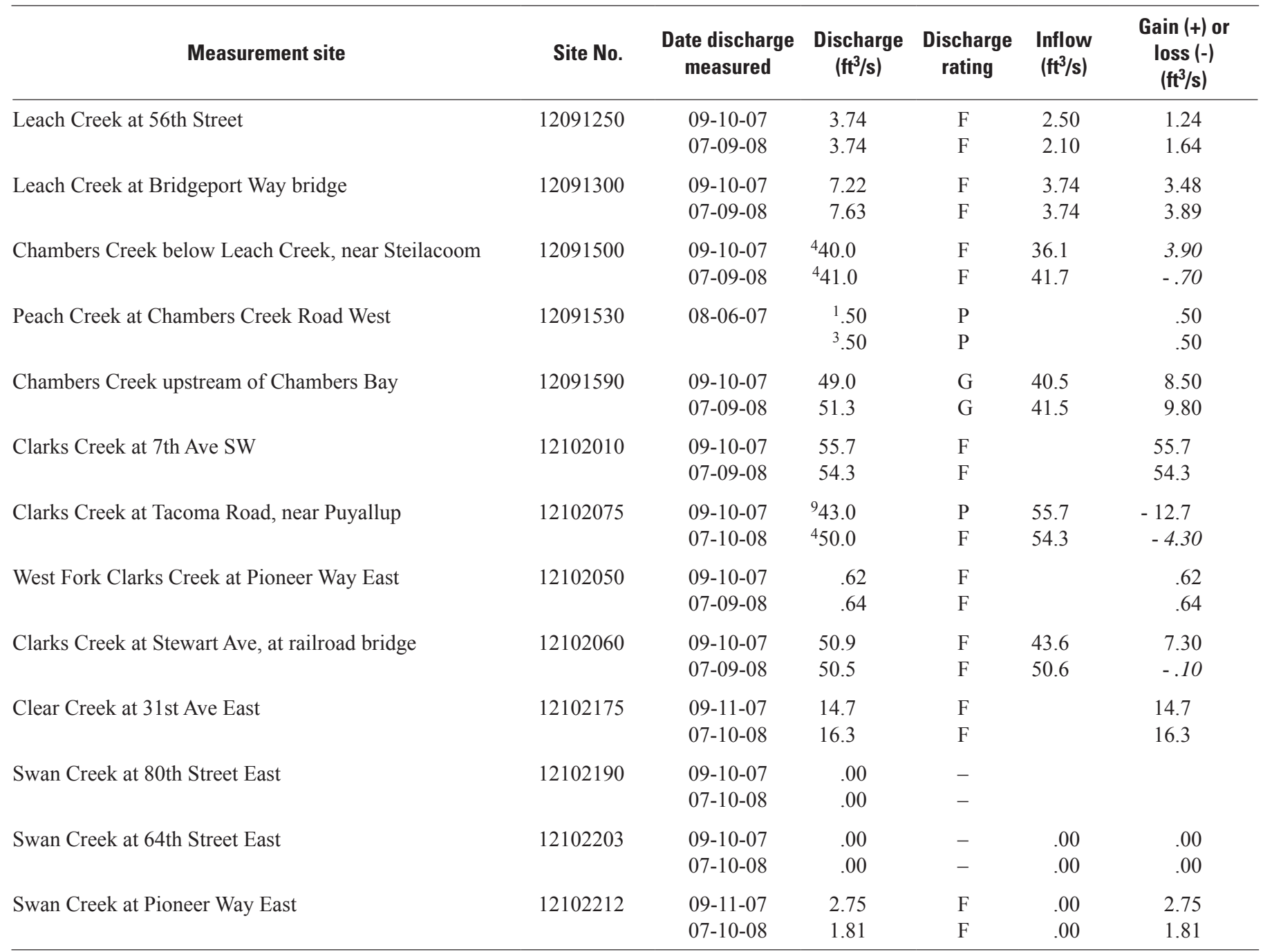

${ }^{1}$ Estimated by U.S. Geological Survey.

${ }^{2}$ Estimated by U.S. Geological Survey based on discharge measurements from nearby sites.

${ }^{3}$ Estimated by U.S. Geological Survey based on discharge measurements from 2007.

${ }^{4}$ Daily mean streamflow at U.S. Geological Survey stream gage.

${ }^{5}$ Includes measured streamflow plus evaporative loss from Spanaway Lake (table 4)

${ }^{6}$ Includes loss from Spanaway Creek to Morey Creek.

${ }^{7}$ Streamflow measured on September 17, 2006, by Pierce Conservation District (written commun., 2008).

${ }^{8}$ Includes measured streamflow plus evaporative loss from Steilacoom Lake (table 4).

${ }^{9}$ Estimated daily mean streamflow at U.S. Geological Survey stream gage. 


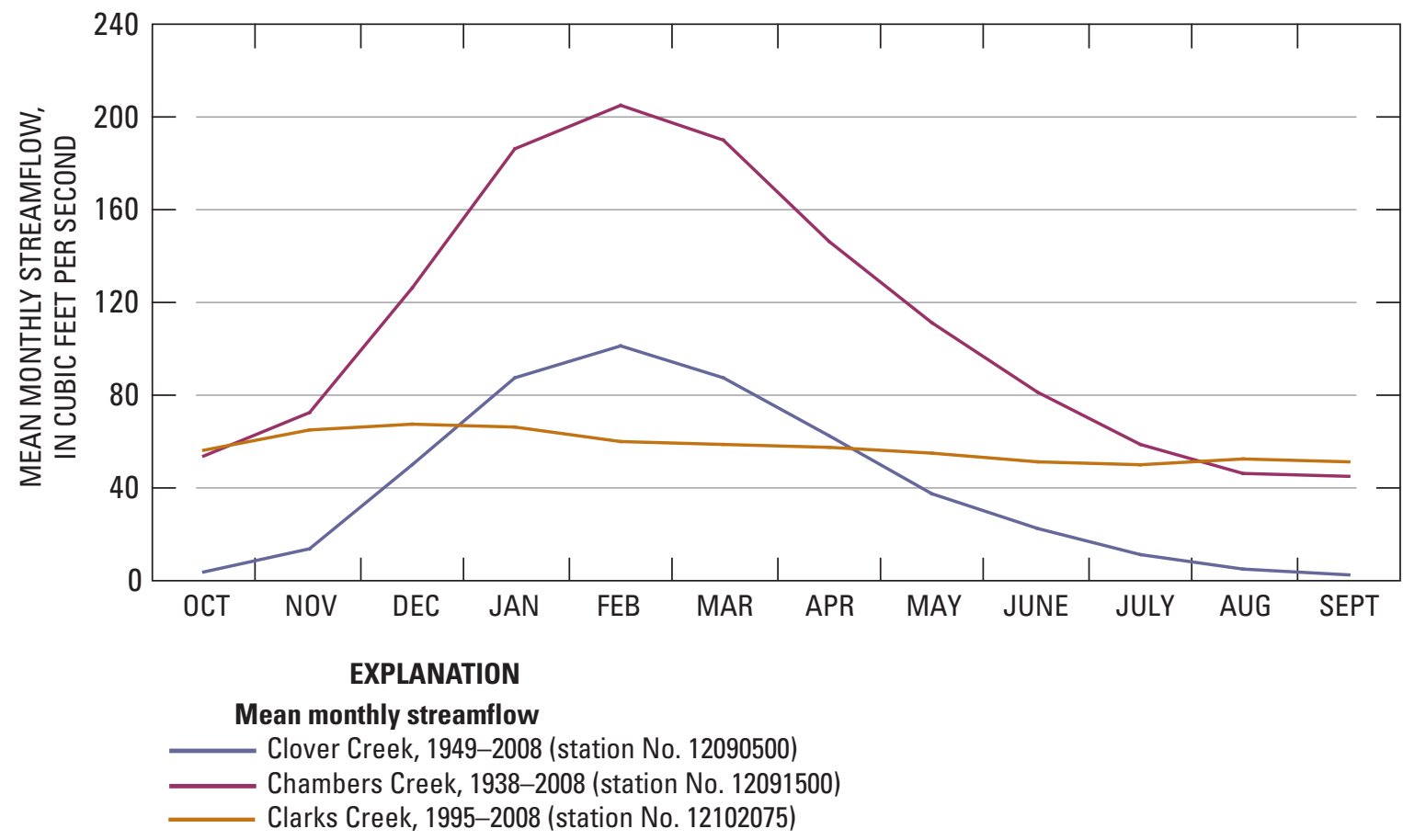

Figure 22. Mean monthly streamflow at U.S. Geological Survey streamflow-gaging stations for Clover Creek (1949-2008), Chambers Creek (1938-2008), and Clarks Creek (1995-2008), Chambers-Clover Creek Watershed and vicinity, Washington.

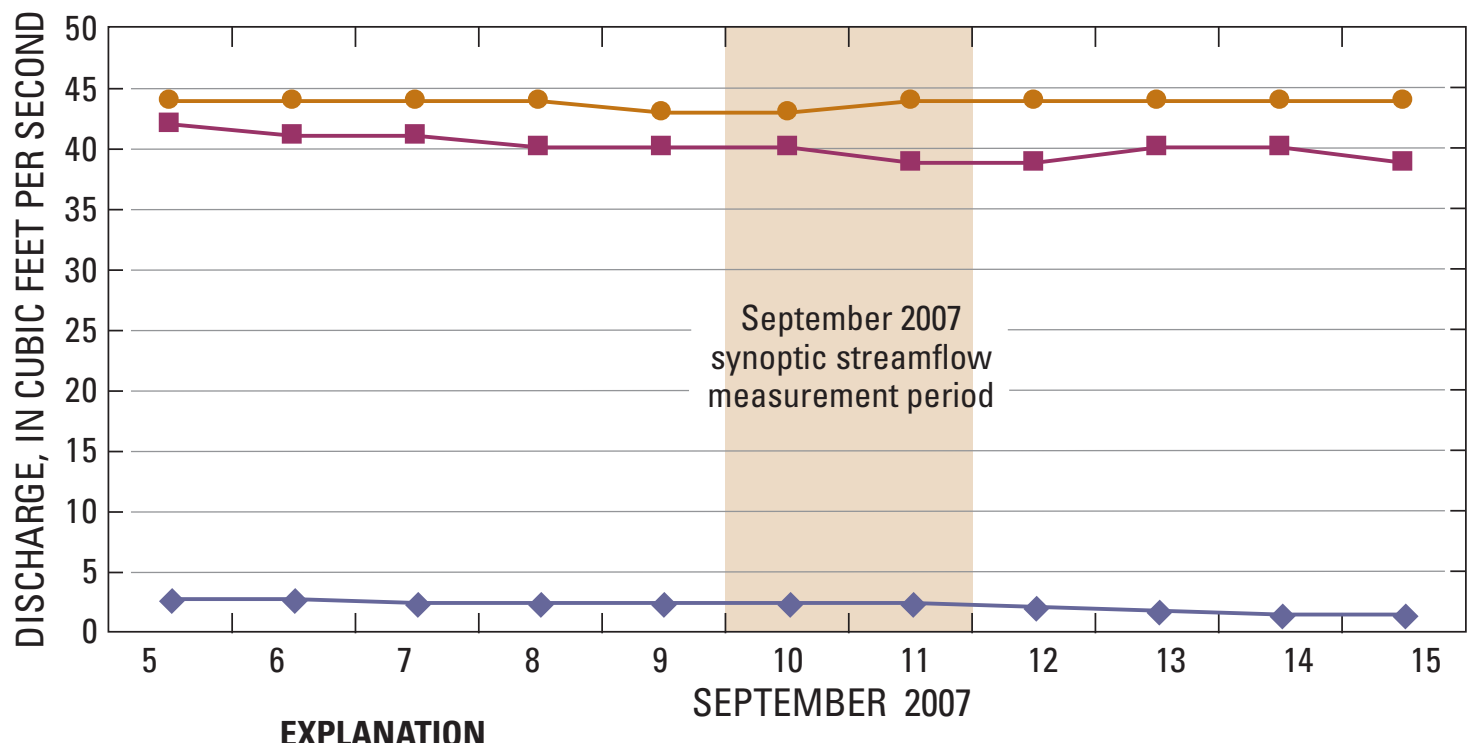

\section{EXPLANATION}

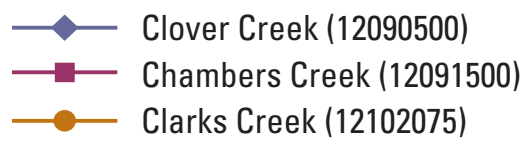

Figure 23. Daily streamflow for U.S. Geological Survey streamflow-gaging stations on Clover Creek (12090500), Chambers Creek (12091500), and Clarks Creek (12102075), Chambers-Clover Creek Watershed and vicinity, Washington, September 5-15, 2007. 


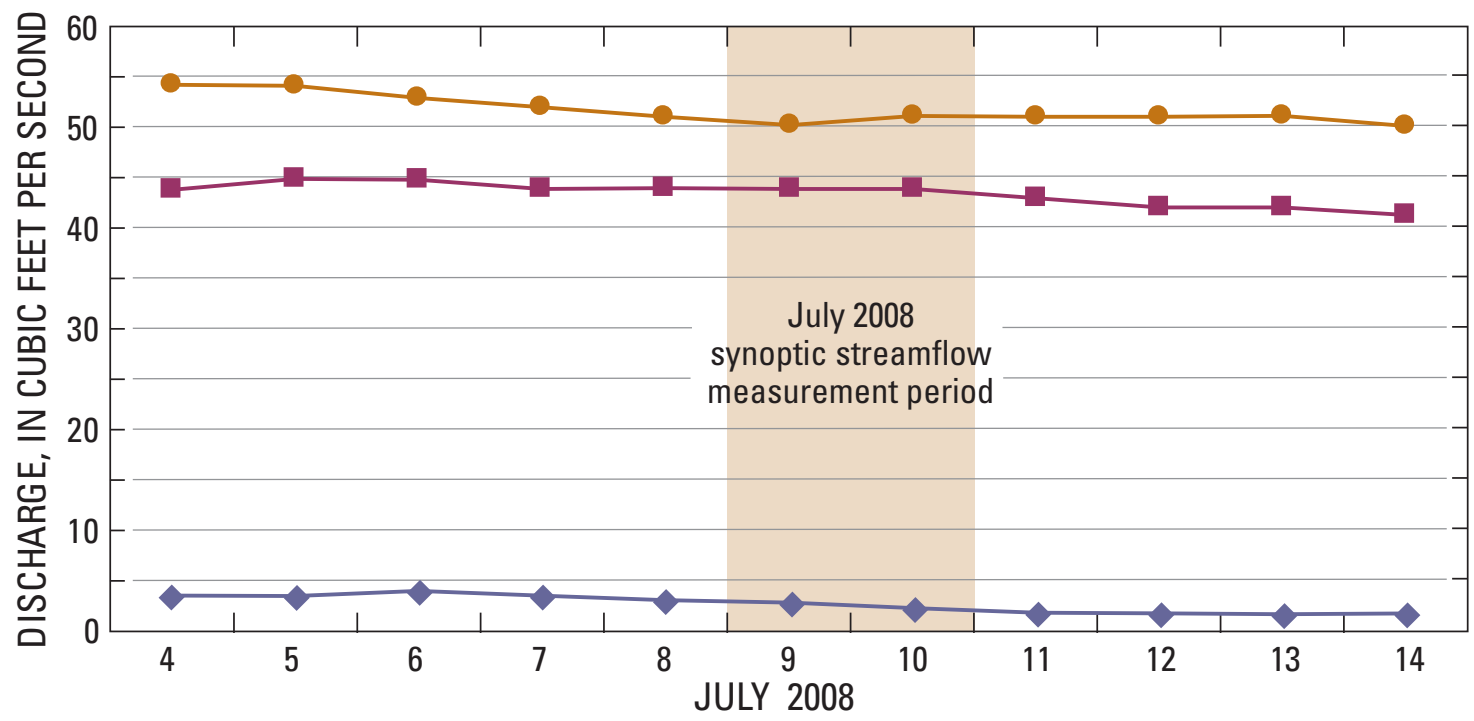

EXPLANATION

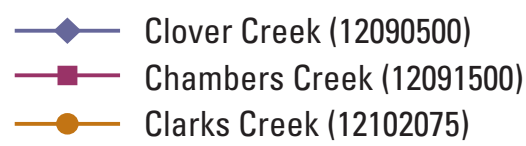

Figure 24. Daily streamflow for U.S. Geological Survey streamflow-gaging stations on Clover Creek (12090500), Chambers Creek (12091500), and Clarks Creek (12102075), Chambers-Clover Creek Watershed and vicinity, Washington, July 4-14, 2008.

The results of the synoptic streamflow measurements are shown in table 5. Most streamflow measurements were rated "fair"; however, 24 measurements were rated "poor" because of suboptimal flow conditions (low velocity, shallow water depth, or the presence of aquatic vegetation) or the need to visually estimate the streamflow value (lack of access to stream). Inflow (table 5) is the sum of streamflows measured upstream of the measurement site and is used to compute the difference between streamflow upstream of the site and at the site. The sign of the difference in streamflow (positive or negative value) indicates a gaining or losing stream reach, respectively. Uncertainties as a result of measurement error were too large at some locations to make defensible conclusions regarding the characterization of gaining or losing stream reaches and those values are italicized in table 5. For example, the September 2007 error adjusted minimum and maximum values for inflow to Muck Creek at $8^{\text {th }}$ Ave. East (12090000), 2.09 and $2.45 \mathrm{ft}^{3} / \mathrm{s}$, respectively, and flow at Muck Creek at $8^{\text {th }}$ Ave. East (12090000), 1.83 and $2.15 \mathrm{ft}^{3} / \mathrm{s}$, respectively, result in a gain or loss uncertainty range (cumulative measurement error) of -0.62 to $0.06 \mathrm{ft}^{3} / \mathrm{s}$. The uncertainty range suggests the possibility of either a gaining or losing stream reach and does not support the characterization of a losing reach indicated by the unadjusted value of $-0.28 \mathrm{ft}^{3} / \mathrm{s}$. Conclusions regarding the characterization of gaining or losing stream reaches were able to be made at most locations (table 5). For example, the July 2008 error adjusted minimum and maximum values for inflow to Muck Creek at $8^{\text {th }}$ Ave. East (12090000), 2.14 and $2.52 \mathrm{ft}^{3} / \mathrm{s}$, respectively, and flow at Muck Creek $8^{\text {th }}$ Ave. East (12090000), 1.52 and $1.78 \mathrm{ft}^{3} / \mathrm{s}$, respectively, result in a gain or loss uncertainty range (cumulative measurement error) of -1.00 to $-0.36 \mathrm{ft}^{3} / \mathrm{s}$, and supports the characterization of a losing reach indicated by the unadjusted value of $-0.68 \mathrm{ft}^{3} / \mathrm{s}$. Other potential sources of error in the characterization of gaining and losing stream reaches include the transient nature of streamflows and errors associated with the time lag between upstream and downstream measurements and unaccounted for tributary inflows within stream reaches.

Streamflow measurements illustrate a complex pattern of gains and loses to streamflows that varies throughout the study area and seems to be affected in places by local topography (pl. 1). The reaches upstream of the uppermost measurement sites on all streams except at Swan Creek gained flow from groundwater discharge. For example, the September 2007 streamflow measurement at Muck Creek at Webster Road (12089980) indicates a net gain of $2.73 \mathrm{ft}^{3} / \mathrm{s}$ from the reach upstream of the measurement site. Intermediate reaches of most streams generally were losing or neutral (no substantial gain or loss), and the lowermost reaches generally were gaining. Substantial groundwater inflows to the lower reaches of Chamber, Clear, and Clarks Creeks likely were due to significant incision of stream channels as they descend to Puget Sound or the Puyallup River valley (pl. 1). Similar gains are likely for the lowermost reaches of Sequilitcheu Creek and the series of streams draining to the Nisqually River valley, although streamflow measurement data are not available. 


\section{Groundwater-Level Fluctuations}

Groundwater levels fluctuate over time, both seasonally and long term (annually), in response to changing rates of groundwater recharge and discharge. When recharge exceeds discharge, the amount of water stored in an aquifer increases and water levels rise; when discharge exceeds recharge, groundwater storage decreases and water levels decline. Groundwater levels also may respond to changes in nearby stream stage. When stream stage (altitude of the water surface) exceeds nearby groundwater levels, streamflow may recharge the aquifer, causing a rise in groundwater levels; when groundwater levels exceed nearby stream stage, discharge from the aquifer to the stream may occur, resulting in a decline in groundwater levels. Seasonal changes in groundwater levels were observed in many wells in the study area (Justin and others, 2009). These observed changes follow a typical pattern for shallow wells in western Washington. Water levels rose in the autumn and winter when precipitation and river stage were high, and declined during spring and summer when precipitation and river stage were low (figs. 25 and 26). Also typical for western Washington was that the peak groundwater levels lagged behind the peak streamflow by a few months, reflecting the storage characteristics of the groundwater system.
The timing and magnitude of seasonal groundwaterlevel fluctuations in an aquifer system are related to (1) the hydraulic characteristics of aquifer materials and adjacent confining units, (2) the presence of unconfined or confined aquifer conditions, (3) the depth to groundwater, (4) the proximity to perennial surface-water features, and (5) the depth of the well and screened intervals being measured. Water levels in deep wells typically respond more slowly and with less magnitude than water levels in shallow wells because deep wells are farther from the recharge source and variability is dampened. Water levels in wells completed in the unconsolidated hydrogeologic units exhibited seasonal variations ranging from less than 1 to about $50 \mathrm{ft}$ (table 6). The largest water-level fluctuation (78 ft) during the monitoring period (March 2007-September 2008) was measured in a well completed in the bedrock unit. Large water-level fluctuations in wells completed in the bedrock unit may be attributed to the presence of water-bearing fractures (high conductivity and low storage) within local outcrop areas receiving precipitation recharge, and the relatively lower (compared to sands and gravels) storage capacity (primary porosity) of consolidated volcanic and sedimentary units (Freeze and Cherry, 1979; Fetter, 1988). Water-level fluctuations measured in the shallow and permeable AL alluvial valley unit were muted because of proximity to perennial streams and rivers; rising groundwater levels in these settings are attenuated by increased discharge to surface water, and declining groundwater levels are ameliorated by increased recharge from surface water.

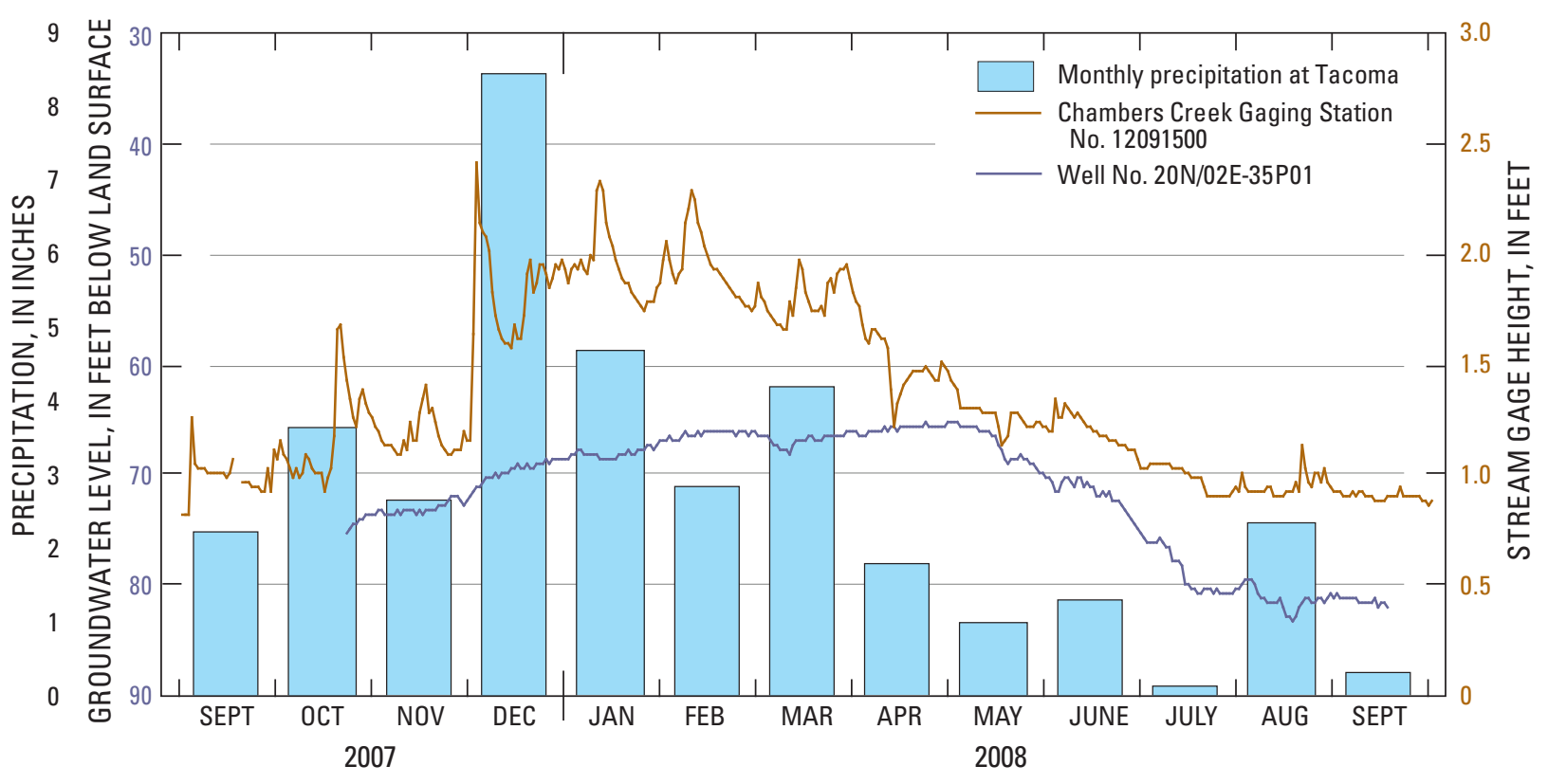

Figure 25. Water levels in well 20N/02E-35P01, stream stage at U.S. Geological Survey streamflowgaging station on Chambers Creek (12091500), and precipitation at Tacoma, Chambers-Clover Creek Watershed and vicinity, Washington, September 2007-September 2008. 


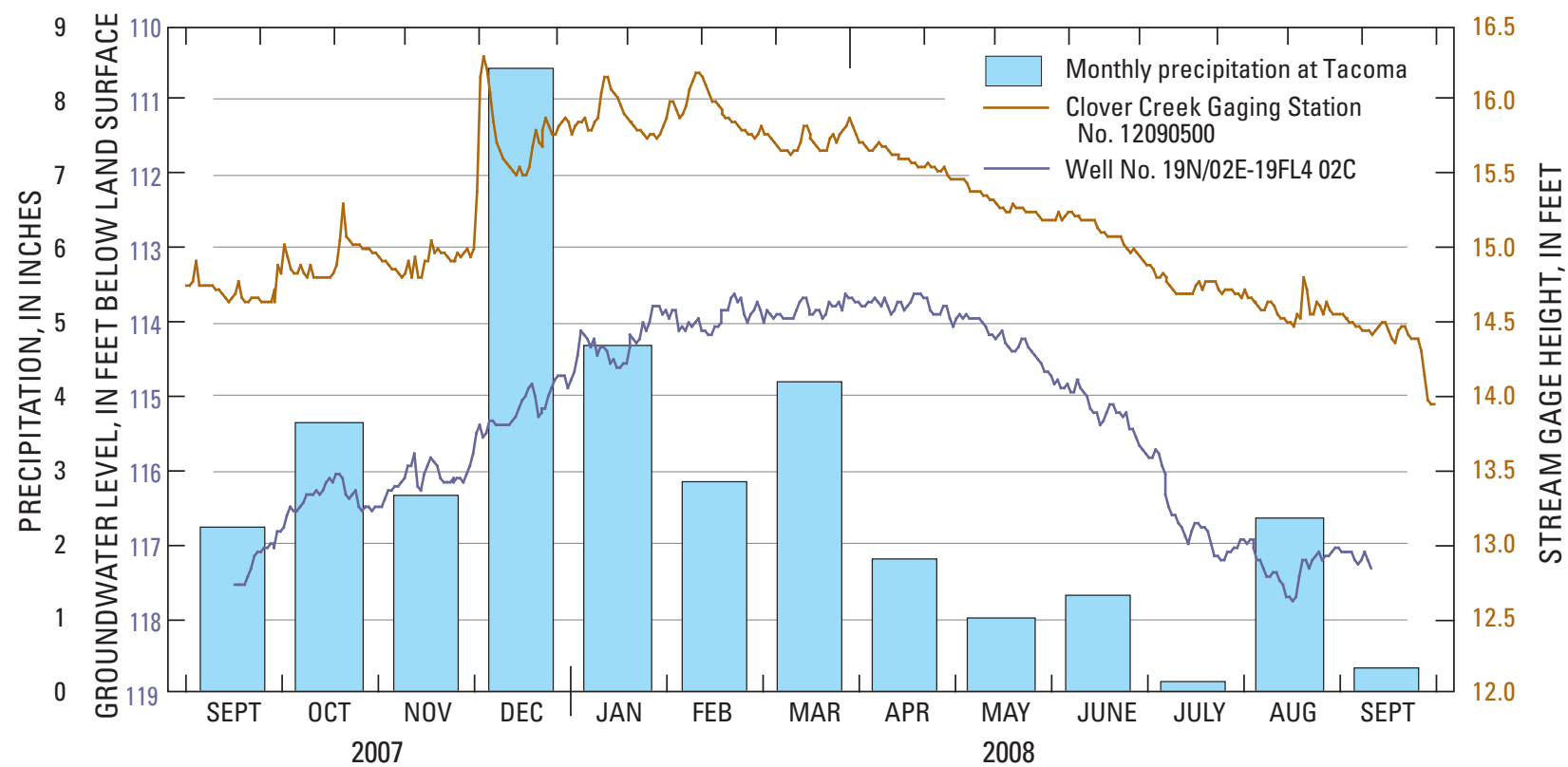

Figure 26. Water levels in well 19N02E-19LF402C, stream stage at U.S. Geological Survey streamflow-gaging station on Clover Creek (12090500), and precipitation at Tacoma, Chambers-Clover Creek Watershed and vicinity, Washington, September 2007-September 2008.

Table 6. Summary of groundwater-level fluctuations and well depths by hydrogeologic unit, Chambers-Clover Creek Watershed, Washington, March 2007 through September 2008.

$[-$, no data $]$

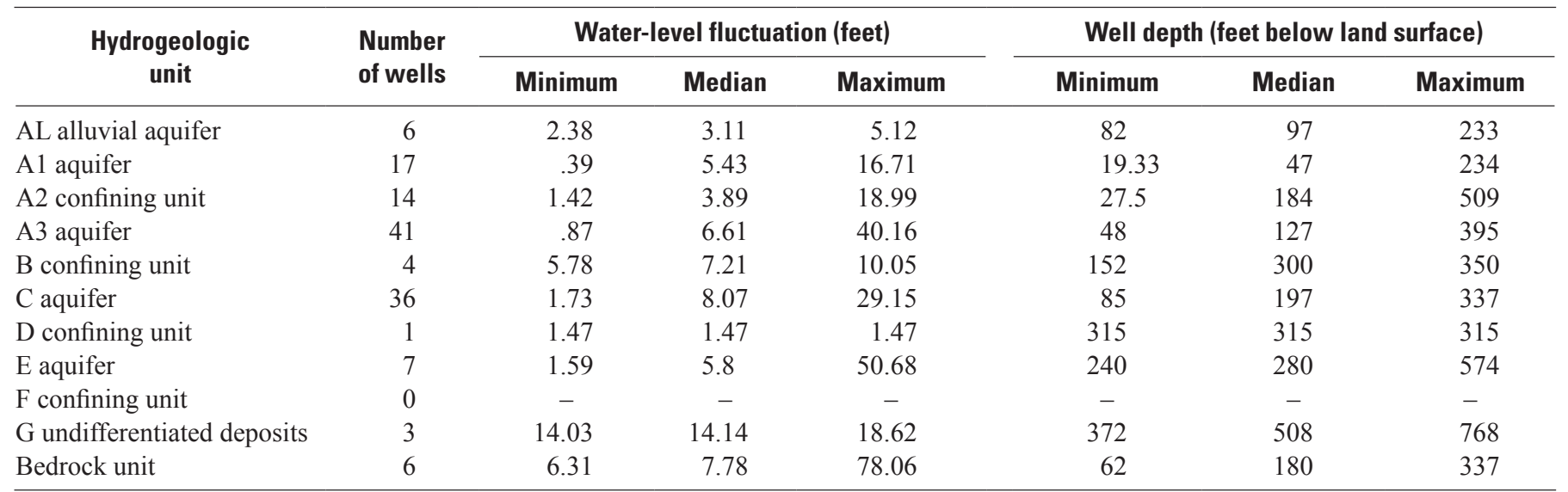




\section{Water Budget}

On a long-term basis, a hydrologic system usually is in a state of dynamic equilibrium; that is, inflow to the system equals outflow from the system, and there is little or no net change in the amount of water stored within the system. An approximate water budget for an average year of precipitation (September 1, 2006, to August 31, 2008) for the water-budget area was calculated (table 7). The water budget assumes there is little or no net change in the amount of water stored within the system (inflow equals outflow). For this assumption to be correct, there should be an absence of long-term trends in groundwater levels in the study area. However, there is no long-term ambient groundwater monitoring network in the study area, and data from the short-term (March 2007-September 2008) monthly monitoring network established for this study are insufficient to evaluate water-level trends relating to long-term changes in groundwater storage. The Tacoma-Pierce County Health Department long-term (1996-2006) groundwater monitoring report (2007) identified "possible declining water levels" in 23 of 70 active public-supply wells in the study area.

Declining water levels were not observed in the remaining 47 wells in the network. The possible presence of long-term water-level declines indicates a potential decrease in water storage and, therefore, suggests the conditions for dynamic equilibrium may not be met at some locations in the study area.

The data and methods used to estimate values of precipitation, groundwater recharge, groundwater discharge to streams and springs, and withdrawals from wells are described in previous sections of this report along with descriptions of the uncertainties associated with the estimates of these budget components. These uncertainties arise from the use of time-averaged and/or area-weighted approximations of precipitation, groundwater discharge, and streamflow; groundwater withdrawal estimates that do not account for potential return flows; and spring flow estimates that do not account for small unreported spring discharges. The water budget is intended to provide an initial estimate of budget components, and due to the above limitations, should be considered an approximation of a complex system.

Surface runoff, including shallow subsurface flow, was computed as the quantity of water remaining after groundwater discharge to streams was subtracted from total measured streamflow. The value for evapotranspiration was computed as the quantity remaining after surface runoff plus groundwater recharge was subtracted from precipitation. Other natural discharge, including unmeasured discharge to the Puyallup and Nisqually Rivers and submarine seepage to Puget Sound, was computed as the quantity of water remaining after groundwater discharge to streams and springs plus withdrawals from wells was subtracted from groundwater recharge. Precipitation during the study period (September 1, 2006, to August 31, 2008) averaged an estimated $45 \mathrm{in} / \mathrm{yr}$ in the area. About 44 percent of
Table 7. Estimated annual water budget for Chambers-Clover Creek Watershed and vicinity, Washington, September 1, 2006, to August 31, 2008.

\begin{tabular}{lcrr}
\hline & \multicolumn{2}{c}{ Quantity } & \\
\cline { 2 - 3 } Water-budget component & $\begin{array}{c}\text { Inches } \\
\text { per year }\end{array}$ & $\begin{array}{c}\text { Acre-feet } \\
\text { per year }\end{array}$ & \\
\hline Precipitation & & & \\
$\quad$ Fate of precipitation & & & \\
$\quad$ Surface runoff & 3 & 65,700 & 7 \\
Evapotranspiration & 22 & 504,300 & 49 \\
$\quad$ Groundwater recharge & 20 & 455,000 & 44 \\
$\quad$ Total precipitation & 45 & $1,025,000$ & 100 \\
Fate of recharge & & & \\
Discharge to streams & 4 & 91,800 & 20 \\
$\quad$ Discharge to springs & 3.5 & 80,000 & 18 \\
Other natural discharge & 10 & 224,700 & 49 \\
$\quad$ Withdrawals from wells & 2.5 & 58,500 & 13 \\
$\quad$ Total recharge & 20 & 455,000 & 100 \\
\hline
\end{tabular}

precipitation enters the groundwater system as recharge. Almost one-half of this recharge (49 percent) discharges to the Puyallup and Nisqually Rivers and leaves the groundwater system as submarine seepage to Puget Sound. The remaining groundwater recharge discharges to streams (20 percent) and springs (18 percent), or is withdrawn from wells (13 percent). The estimated magnitude of submarine groundwater discharge from the area is highly uncertain because it incorporates all inaccuracies in the other water-budget component estimates, and no attempts have been made to measure it directly. Submarine groundwater discharge is a potentially significant unknown because it represents a potential groundwater resource that could be withdrawn without impact to freshwater instream flows.

\section{Summary and Conclusions}

In 1998, the Washington State Legislature established the Washington State Watershed Management Act (codified under RCW 90.82) to address diminishing water availability and quality and the loss of critical habitat for fish and wildlife. Watershed studies under this Act were started in 1998 in the Chambers-Clover Creek Watershed (CCCW) Water Resources Inventory Area (WRIA 12) by a group of Initiating Governments and local stakeholders (Planning Unit). Upon completion of a technical assessment of the watershed, some members of the Planning Unit concluded that additional data, including development of a numerical groundwater-flow model, would contribute to an improved understanding of water resources in the $\mathrm{CCCW}$. A study to characterize the groundwater-flow system in the Chambers-Clover Creek 
Watershed and vicinity was conducted by the U.S. Geological Survey. A second phase of this project will integrate this and other information into a numerical groundwater-flow model to contribute to an improved understanding of water resources in the $\mathrm{CCCW}$.

The study area covers about $706 \mathrm{mi}^{2}$ in western Pierce County, Washington, and extends north to the Puyallup River, southwest to the Nisqually River, and is bounded on the south and east by foothills of the Cascade Range and to the west by the Puget Sound. The Puyallup and Nisqually Rivers occupy large, relatively flat alluvial valleys that are separated by a broad, poorly drained, upland area that covers most of the study area. The northwest-flowing Puyallup River receives streamflow from several north-flowing streams (Swan, Clear, and Clarks Creeks) that originate in the northern uplands. Chambers and Clover Creeks drain much of the central uplands and flow westward to Puget Sound. Muck and Lacamas Creeks, and several smaller tributaries to the northwest-flowing Nisqually River, drain the southern part of the study area. Many stream reaches flow year-round; however, intermittent and ephemeral flow conditions are common, especially during the summer months. Numerous springs are present throughout the study area and contribute late-summer baseflow to streams and year-round groundwater discharge to Puget Sound along shoreline bluffs. The study area is underlain by a northwest-thickening sequence of unconsolidated glacial (till and outwash) and interglacial deposits (fluvial and lacustrine), which overlie sedimentary and volcanic bedrock units that crop out in the foothills along the southern and southeastern margin of the study area.

Geologic units were grouped into 10 hydrogeologic units consisting of aquifers and confining units. A surficial hydrogeologic unit map was constructed and used with well information from 450 drillers' logs to produce six hydrogeologic sections and unit extent and thickness maps.

Unconsolidated aquifers (AL, A1, A3, C, E, and G) typically consist of moderately to well-sorted alluvial and glacial outwash deposits of sand, gravel, and cobbles, with minor lenses of silt and clay. These units often occur as discontinuous or isolated bodies and are of highly variable thickness. Unconfined conditions occur in areas where aquifer units are at land surface; however, much of the study area is mantled by glacial till, and confined aquifer conditions are common. Groundwater in the unconsolidated aquifers generally flows to the northwest in the direction of Puget Sound, and to the north and northeast towards the Puyallup River. These generalized flow patterns likely are complicated by the presence of low permeability confining units that separate discontinuous bodies of aquifer material and act as local groundwater-flow barriers. Water-level differences between the $\mathrm{A} 3$ and $\mathrm{C}$ aquifers show the potential for downward vertical flow in western and eastern parts of the study area. The potential for upward groundwater movement, indicated by the presence of flowing wells, was observed at several locations within the aquifer units.
Unconsolidated confining units (A2, B, D, and F) typically consist of poorly sorted glacial till, and glaciolacustrine and interglacial deposits of clay, silt, sand, gravel, cobbles, and boulders, with a few locally occurring sand and gravel lenses capable of providing water for domestic use. Unconsolidated aquifer and confining units are underlain by Tertiary bedrock units primarily consisting of sedimentary claystone, siltstone, sandstone, beds of coal, and volcanic rocks. These units, described as the basement confining unit by Jones (1999), are not considered part of the active groundwater-flow system.

The largest groundwater-level fluctuation $(78 \mathrm{ft})$ observed during the monitoring period (March 2007-September 2008) was in a well completed in the bedrock unit. Water levels in wells completed in the unconsolidated hydrogeologic units showed seasonal variations ranging from less than 1 to about $50 \mathrm{ft}$.

Synoptic streamflow measurements made in September 2007 and July 2008 indicate a total groundwater discharge to streams in the study area of 87,310 and 92,160 acre-ft/yr, respectively. Streamflow measurements indicate a complex pattern of gains and losses to streamflows that varies throughout the study area and seems to be affected in places by local topography. Groundwater discharge occurs at numerous springs in the area, and the total previously reported discharge of springs in the area is about $80,000 \mathrm{acre}-\mathrm{ft} / \mathrm{yr}$. There are, in addition, many unmeasured springs and the total spring discharge in the area is unknown.

The water-budget area, a subarea of the study area, received an average (September 2, 2006, to August 31, 2008) of about 1,025,000 acre- $\mathrm{ft}$ or about $45 \mathrm{in} / \mathrm{yr}$ of precipitation a year. About 44 percent of precipitation enters the groundwater system as recharge. Almost one-half of this recharge (49 percent) discharges to the Puyallup and Nisqually Rivers and leaves the groundwater system as submarine groundwater discharge to Puget Sound. The remaining groundwater recharge discharges to streams ( 20 percent) and springs (18 percent), or is withdrawn from wells (13 percent).

\section{Acknowledgments}

The authors wish to thank the many well owners in the study area who provided access to their wells. The authors also acknowledge the assistance and information provided by public water-supply systems and water districts; these include Spanaway Water Company, Fruitland Mutual Water Company, Parkland Light and Water Company, Summit Water and Supply Company, Lakewood Water District, and the cities of Tacoma, Milton, and Fife. The authors also thank Tacoma-Pierce County Health Department, Pierce County Water Utility, and Fort Lewis for providing well data. Information used to characterize the groundwater-flow system was generously provided by Robinson \& Noble Inc., and the Pacific Groundwater Group. 


\section{References Cited}

Bauer, H.H., and Mastin, M.C., 1997, Recharge from precipitation in three small glacial-till-mantled catchments in the Puget Sound lowland, Washington: U.S. Geological Survey Water-Resources Investigations Report 96-4219, 119 p. (Also available at http://pubs.er.usgs.gov/usgspubs/ wri/wri964219).

Bear, Jacob, 1979, Hydraulics of groundwater: New York, McGraw-Hill, 569 p.

Bidlake, W.R., and Payne, K.L., 2001, Estimating recharge to ground water from precipitation at Naval Submarine Base Bangor and Vicinity, Kitsap County, Washington: U.S. Geological Survey Water- Resources Investigations Report 01-4110, 33 p.

Blair, H.O., 1929, Underground water resources in the vicinity of Tacoma: Journal of the American Water Works Association, v. 21, no. 9, p. 1185-1195.

Borden, R.K., and Troost, K.G., 2001, Late Pleistocene stratigraphy in the south-central Puget Lowland, Pierce County, Washington: Washington Division of Geology and Earth Resources Report of Investigations 33, 34 p.

Brown and Caldwell, 1985, Clover/Chambers Creek geohydrologic study for Tacoma-Pierce County Health Department: Seattle, WA, Brown and Caldwell, unpaginated.

Carnahan, B., Luther, H.A., and Wilkes, J.O., 1969, Applied numerical methods: New York, John Wiley and Sons, Inc., $604 \mathrm{p}$.

Daly, Christopher, Neilson, R.P., and Phillips, D.L., 1994, A statistical-topographic model for mapping climatological precipitation over mountainous terrain: Journal of Applied Meteorology, v. 33, no. 2, p. 140-158.

Carr/Associates Inc., 1988, Report on the 1987-88 test drilling program for the City of Tacoma

Drost, B. W., 2005, Quality-assurance plan for groundwater activities, U.S. Geological Survey, Washington Water Science Center: U.S. Geological Survey Open-File Report 05-1126, 27 p. (Also available at http://pubs.usgs. gov/of/2005/1126/.)

Drost, B.W., Ely, D.M., and Lum II, W.E., 1999, Conceptual model and numerical simulation of the ground-water-flow system in the unconsolidated sediments of Thurston County, Washington: U.S. Geological Survey Water-Resources Investigations Report 99-4165, 254 p. (Also available at http://pubs.usgs.gov/wri/wri994165/).
Ferris, J.G., Knowles, D.B., Brown, R.H., and Stallman, R.W., 1962, Theory of aquifer tests: U.S. Geological Survey Water-Supply Paper 1536-E, 174 p. (Also available at http://pubs.usgs.gov/wsp/wsp1536-E/).

Fetter, C.W., 1988, Applied hydrogeology: Columbus, Ohio, Merrill Publishing Company, 592 p.

Freeze, R.A., and Cherry, J.A., 1979, Groundwater: Englewood Cliffs, N.J., Prentice-Hall, 604 p.

Hutchinson, M.F., 1989, A new method for gridding elevation and streamline data with automatic removal of pits: Journal of Hydrology, v. 106, p. 211-232.

Jones, M.A., 1999, Geologic framework for the Puget Sound aquifer system, Washington and British Columbia: U.S. Geological Survey Professional Paper 1424-C, 31 p., 18 pls., scales $1: 500,000$ and 1:100,000. (Also available at http://pubs.er.usgs.gov/usgspubs/pp/pp1424C).

Jones, M.A., Orr, L.A., Ebbert, J.C., and Sumioka, S.S., 1999, Ground-water hydrology of the Tacoma-Puyallup area, Pierce County, Washington: U.S. Geological Survey Water-Resources Investigations Report 99-4013, 154 p.

Justin, G.B., Julich, R., and Payne, K.L., 2009, Hydrographs showing groundwater level changes for selected wells in the Chambers-Clover Creek Watershed and vicinity, Pierce County, Washington: U.S. Geological Survey Data Series 453. (Also available at http://pubs.usgs.gov/ds/453/).

Mastin, M.C., 1996, Surface-water hydrology and runoff simulations for three basins in Pierce County, Washington: U.S. Geological Survey Water-Resources Investigations Report 95-4068, 148 p. (Also available at http://pubs. er.usgs.gov/usgspubs/wri/wri954068).

National Land Cover Database, 2001: accessed May, 2009, http://www.mrlc.gov/multizone_download.php?zone=1.

National Oceanic and Atmospheric Administration, 1982, Evaporation atlas for the contiguous 48 United States: NOAA Technical Report NWS 33, 27 p., 4 pls.

National Oceanic and Atmospheric Administration, 2007, Climatological data, annual summary, Washington, 2007: Asheville, N.C., National Climatic Data Center, v.111, no. $13,30 \mathrm{p}$.

Noble, J.B., 1990, Proposed revision of nomenclature for the Pleistocene stratigraphy of coastal Pierce County, Washington: Washington Division of Geology and Earth Resources Open File Report 90-4, 54 p.

Oregon State University, 2009, PRISM Products: accessed May, 2009 at http://www.prism.oregonstate.edu. 
Rantz, S.E., and others, 1982, Measurement and computation of streamflow, volume 1-Measurement of stage and discharge: U.S. Geological Survey Water-Supply

Paper 2175, 284 p. (Also available at http://pubs.usgs.gov/ wsp/wsp2175).

Robinson \& Noble, Inc., and others, 2003, Chambers-Clover Technical Assessment - final report: Tacoma, Washington.

Sceva, J.E., Wegner, D.E., and others, 1955, Records of wells and springs, water levels, and quality of ground water in central Pierce County, Washington: U.S. Geological Survey Open-File Report, 261 p.

Schasse, H.W., compiler, 1987, Geologic map of the Centralia quadrangle, Washington: Washington Division of Geology and Earth Resources Open File Report 87-11, 28 p., 1 pl., scale 1:100,000.

Troost, K.G., in press, Geologic map of the Tacoma South 7.5-minute quadrangle, Washington: U.S. Geological Survey Miscellaneous Field Investigation, scale 1:24,000.

Troost, K.G., in press, Geologic map of the Puyallup 7.5-minute quadrangle, Washington: U.S. Geological Survey Miscellaneous Field Investigation, scale 1:24,000.

Troost, K.G., and Booth, D.B., in press, Geologic map of the Tacoma North 7. 5-minute quadrangle, Washington, U.S. Geological Survey Miscellaneous Field Investigation, scale 1:24,000.

Troost, K.G., Booth, D.B., and Borden, R.K., in press, Geologic map of the Steilacoom 7.5-minute quadrangle, Washington: U.S. Geological Survey Miscellaneous Field Investigation, scale 1:24,000.

Troost, K.G., Booth, D.B., and Wells, R.E., in press, Geologic map of the Gig Harbor 7.5-minute quadrangle, Washington: U.S. Geological Survey Miscellaneous Field Investigation, scale 1:24,000.
Turney, G.L., Kahle, S.C., and Dion, N.P., 1995, Geohydrology and ground-water quality of east King County, Washington: U.S. Geological Survey WaterResources Investigations Report 94-4082, 123 p. (Also available at http://pubs.er.usgs.gov/usgspubs/wri/ wri944082).

U.S. Department of Commerce Burea of Census, 2007: accessed July, 2007 at http://www.census.gov/popest/ counties/tables/CO-EST2008-01-53.xls.

Vaccaro, J.J., Hansen, A.J., and Jones, M.S., 1998, Hydrogeologic framework for the Puget Sound aquifer system, Washington and British Columbia: U.S. Geological Survey Professional Paper 1424-D, 77 p. (Also available at http://pubs.er.usgs.gov/usgspubs/pp/pp1424D).

van Heeswijk, Marijke, and Smith, D.T., 2002, Simulation of the ground-water flow system at Naval Submarine Base Bangor and vicinity, Kitsap County, Washington: U.S. Geological Survey Water-Resources Investigations Report 02-4261, 142 p. (Also available at http://pubs.usgs.gov/wri/ wri024261/).

Walsh, T.J., 1987, Geologic map of the south half of the Tacoma quadrangle, Washington: Washington Division of Geology and Earth Resources Open File Report 87-3, 10 p., 1 pl., scale 1:100,000.

Walters, K.L., and Kimmel, G.E., 1968, Ground-water occurrence and stratigraphy of unconsolidated deposits, central Pierce County, Washington: Washington State Department of Water Resources Water-Supply Bulletin no. 22,428 p.

Washington State Department of Health Office of Drinking Water, 2007, public water systems data: accessed March, 2007 at http://www.doh.wa.gov/ehp/dw/our_main_pages/ data_download.html. 
This page intentionally left blank. 
Publishing support provided by the U.S. Geological Survey

Publishing Network, Tacoma Publishing Service Center

For more information concerning the research in this report, contact the Director, Washington Water Science Center

U.S. Geological Survey,

934 Broadway -Suite 300

Tacoma, Washington 98402

http://wa.water.usgs.gov/ 
